\title{
Developments of the Electroactive Materials for Non-Enzymatic Glucose Sensing and Their Mechanisms
}

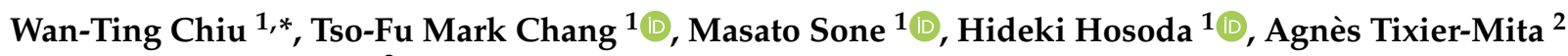 \\ and Hiroshi Toshiyoshi ${ }^{2}$ \\ 1 Institute of Innovative Research (IIR), Tokyo Institute of Technology, 4259 Nagatsuta-cho, Midori-ku, \\ Yokohama 226-8503, Japan; chang.m.aa@m.titech.ac.jp (T.-F.M.C.); sone.m.aa@m.titech.ac.jp (M.S.); \\ hosoda.h.aa@m.titech.ac.jp (H.H.) \\ 2 Institute of Industrial Science (IIS), The University of Tokyo, 4-6-1 Komaba, Meguro-ku, \\ Tokyo 153-8505, Japan; agnes@iis.u-tokyo.ac.jp (A.T.-M.); hiro@iis.u-tokyo.ac.jp (H.T.) \\ * Correspondence: chiu.w.aa@m.titech.ac.jp; Tel.: +81-45-924-5061
}

Citation: Chiu, W.-T.; Chang, T.-F.M.; Sone, M.; Hosoda, H.; Tixier-Mita, A.; Toshiyoshi, H. Developments of the Electroactive Materials for Non-Enzymatic Glucose Sensing and Their Mechanisms. Electrochem 2021, 2,347-389. https://doi.org/10.3390/ electrochem 2020025

Academic Editor: Michael EG Lyons

Received: 18 May 2021

Accepted: 15 June 2021

Published: 21 June 2021

Publisher's Note: MDPI stays neutral with regard to jurisdictional claims in published maps and institutional affiliations.

Copyright: (c) 2021 by the authors. Licensee MDPI, Basel, Switzerland. This article is an open access article distributed under the terms and conditions of the Creative Commons Attribution (CC BY) license (https:// creativecommons.org/licenses/by/ $4.0 /)$.

\begin{abstract}
A comprehensive review of the electroactive materials for non-enzymatic glucose sensing and sensing devices has been performed in this work. A general introduction for glucose sensing, a facile electrochemical technique for glucose detection, and explanations of fundamental mechanisms for the electro-oxidation of glucose via the electrochemical technique are conducted. The glucose sensing materials are classified into five major systems: (1) mono-metallic materials, (2) bi-metallic materials, (3) metallic-oxide compounds, (4) metallic-hydroxide materials, and (5) metal-metal derivatives. The performances of various systems within this decade have been compared and explained in terms of sensitivity, linear regime, the limit of detection (LOD), and detection potentials. Some promising materials and practicable methodologies for the further developments of glucose sensors have been proposed. Firstly, the atomic deposition of alloys is expected to enhance the selectivity, which is considered to be lacking in non-enzymatic glucose sensing. Secondly, by using the modification of the hydrophilicity of the metallic-oxides, a promoted current response from the electro-oxidation of glucose is expected. Lastly, by taking the advantage of the redistribution phenomenon of the oxide particles, the usage of the noble metals is foreseen to be reduced.
\end{abstract}

Keywords: chemical sensing; electroactive materials; electrochemical technique; glucose sensors; metallic nanomaterials; oxide nanomaterials

\section{Introduction}

According to the International Diabetes Federation (IDF), diabetes, which is a serious and long-term health care issue, is among the top 10 causes of death in adults [1]. Possible complications, including retinopathy, nephropathy, neuropathy, and so forth [2-4], could take place and have a great influence on the quality of life (QoL). It was also reported that diabetes has brought about 4 million deaths globally and the expenditure on diabetes care was estimated to be up to USD 727 billion in 2017 [1]. The early detection of the glucose concentration in the human body and the continuous monitoring of glucose concentration in patients by the glucose sensor, which possesses high sensitivity, high selectivity, good long-term stability, and so forth, have thus become critical issues.

From the materials point of view, the glucose sensors are generally categorized into two types: (1) enzymatic glucose sensors [5-7] and (2) non-enzymatic glucose sensors [8-10]. From the device point of view, on the other hand, the glucose sensors could be typically divided into two different classifications: (1) invasive glucose sensors and (2) non-invasive glucose sensors. The introductions to the various classifications of the glucose sensors in terms of both the materials and the devices are as follows.

The first material for the enzymatic glucose sensor was developed by Clark and Lyons [7] in 1962. Thereafter, the realization of the glucose sensor electrode was achieved 
by Updike and Hicks [6] in 1967. From then on, much effort has been made to enhance the performances of the enzymatic glucose sensors in those few decades [11-16]. In the case of the enzymatic type glucose sensor, for the detection of glucose concentration in different human physiological fluids, glucose oxidase (GOx) [17-20] and glucose dehydrogenase (GDH) [21-24] are frequently utilized enzymes. However, based on the reports from Wilson and Turner [25] and other literature [26,27], the activity of the GOx deteriorated immediately as the operating $\mathrm{pH}$ went below 2 or beyond 8 . In addition, fatal damages were also brought to $\mathrm{GOx}$ when the operating temperature was higher than $40^{\circ} \mathrm{C}$. Similar to the GOx enzyme, there is also a stability issue in the GDH enzyme as the $\mathrm{pH}$ and temperature are out of stable ranges of the GDH enzyme [28,29]. In addition to the aforementioned stability dilemma, immobilizations of enzymes are essential requirements but could be complicated, time-consuming, and expensive [30-33]. Therefore, the nonenzymatic glucose sensor, which possesses high stability, high sensitivity, low cost, good long-term stability, and proper selectivity, has attracted much attention in the glucosesensing community. The selectivity, which is strongly dependent on the detection potential, is further discussed in Sections 7.3 and 7.5.

In this article, the non-enzymatic glucose sensors are further classified into five major systems: (1) mono-metallic-based [34,35], (2) bi-metallic-based [36,37], (3) metallic-oxidebased [38-40], (4) metallic-hydroxide-based [41], and (5) mixtures of the metal/metal derivative-based electrodes [42-46]. Besides the aforementioned metal and/or metal derivative-based catalysts, supporting materials, which could enhance the overall electrode stability, the overall electrical conductivity of the electrode, the surface area of active materials, and the strength of the electroactive sites, have been often utilized [47-51]. Among the supporting materials, multi-walled carbon nanotube (MWCNT) $[36,48,50,51]$, graphene sheet [35], polyaniline (PANI) [42,47], graphene oxide [49], and so on, are often seen materials. In the consideration of the functionality, carbon materials provide a higher surface area of the electroactive materials, while PANI promoted the overall electrical conductivity. Furthermore, surface chemistry, which strongly affects the performance of the electrodes, could be fine-tuned via the manipulation of the functional groups on the supporting materials. In addition to the abovementioned materials, by controlling the microstructures of the electroactive materials and the supporting materials, the variety and the possibilities for the performance enhancement of the glucose-sensing electrodes could be almost unlimited. For example, $\mathrm{Pd}$ nanocubes [34], $\mathrm{CuO}$ nanowires [38], $\mathrm{NiO}$ hollow spheres [39], $\mathrm{Fe}_{2} \mathrm{O}_{3}$ nanowire arrays [52], $\mathrm{Au} @ \mathrm{Cu}_{2} \mathrm{O}$ core-shell structure [43], $\mathrm{AgNPs} / \mathrm{CuO}$ nanofibers [44], and $\mathrm{NiO}-\mathrm{Ag}$ nanofibers [46] have been claimed to promote the performances, such as the detection sensitivity, selectivity, long-term stability, detection potential, and so on.

Most of the commercialized glucose sensors are enzymatic ones [8]. However, nonenzymatic glucose sensors are expected to have high potential because of their relatively high environmental stability [53-55], good sensitivity [56,57], high long-term stability [58], and time-efficient manufacture [42,59]. Literature reporting the non-enzymatic glucose sensor published between 2000 and 2020 is shown in Figure 1.

It is obvious that the literature amount of the non-enzymatic glucose sensors increased year by year due to the critical applications in the health care and medical fields. Although it was reported that there might be a selectivity issue in the non-enzymatic glucose sensors compared with the enzymatic ones [60], it has been revealed that the selectivity issue could be overcome by various approaches [61-63]. Strategies for the enhancement of the selectivity of the non-enzymatic glucose sensors are explained in detail in Sections 7.3 and 7.5.

In addition, the detection of the glucose concentration in the human physiological fluids could be simply accomplished by the facile electrochemical technique [64-67], which is utilized in cooperation with the non-enzymatic glucose electrodes. An illustration of the glucose concentration detection system via the electrochemical technique is shown in Figure 2. Firstly, in Figure 2a, the yellow spheres on the dark blue square electrode plate indicate the electroactive sites, which are the most critical materials for the electro-oxidation of glucose in the electrochemical cells. The green target materials showing polygon structure 
suggest glucose molecules in the electrolyte, such as human physiological fluids. The target materials are thus electro-oxidized on the surface of the electroactive materials. Secondly, the current generated from the electro-oxidation reactions flows out of the electrochemical cell, enters the external circuit, and is processed by the transducer and amplifier (Figure $2 b$ ). Finally, the detected current is processed by the signal processor and is transformed into meaningful information, such as glucose concentration (Figure 2c). Therefore, under such a premise, a comprehensive review article of the non-enzymatic electrodes for the glucose sensor toward the health care and medical applications was conducted.

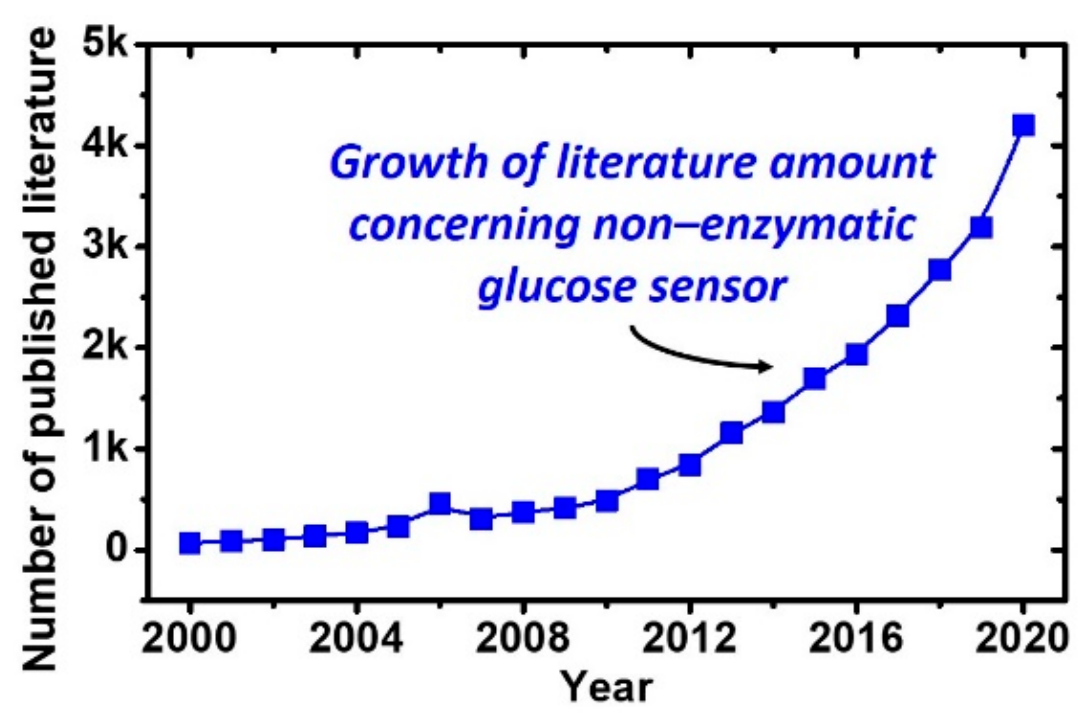

Figure 1. The number of literature concerning the non-enzymatic glucose sensors since 2000. (Data resource from Google Scholar).

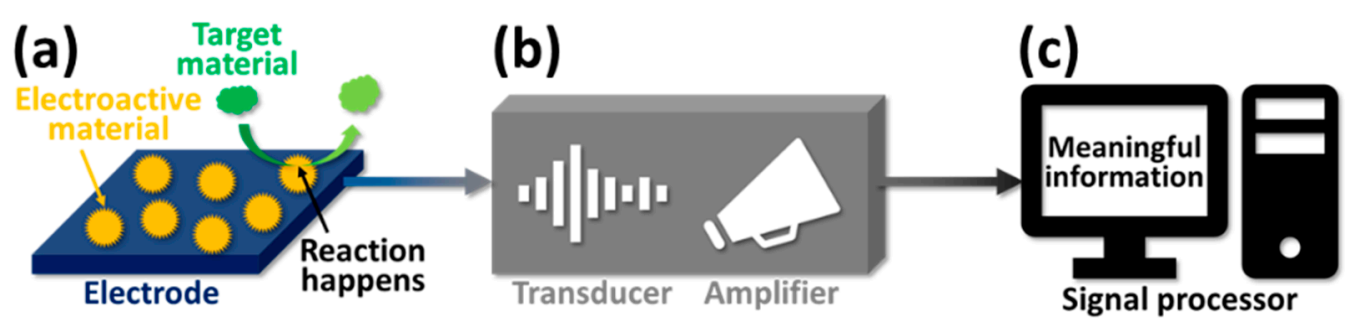

Figure 2. An illustration of the glucose concentration detection system via the electrochemical technique and the following signal processes. (a) Firstly, electro-oxidation of glucose target on the surface of the electroactive materials, which is deposited on the substrate. (b) Secondly, the current response is processed by the transducer and amplifier. (c) Finally, the current response is information-processed to extract characteristic parameters by the signal processor.

\section{Types of Glucose-Sensing Devices}

To date, the devices for the glucose sensors could be divided into two major different types [21,68,69]: (1) the conventional invasive glucose sensor and (2) the advanced noninvasive glucose sensor. Brief introductions to these two different types of glucose sensors are described in the following sections.

\subsection{Invasive Glucose Sensor Devices}

It is widely known that, in the past, for the detection of glucose concentration in the human blood, it was necessary to invasively stab into fingertips and place the blood on the disposable strip of the glucometer [70]. For reducing the repeated acquiring of the human blood in the aforementioned method, an implantable glucometer, which detects and transmits the glucose concentration along with a wireless monitor, was developed [71]. This could reduce the irritating, multifarious, and repeated processes of fingertip stabbing. 
However, surgery is necessary for the implantation of the glucometer into the human body. Therefore, non-invasive glucose sensors are greatly required for the replacement of invasive glucose sensors in the glucose-sensing community.

\subsection{Non-Invasive Glucose Sensor Devices}

Advanced non-invasive glucose sensors have been developed for solving the abovementioned problems in conventional invasive glucose sensors. Firstly, soft contact lens, which were equipped with integrated circuit (IC) chips, antenna, and glucose sensor, have been developed for the detection of the glucose concentration in the tears [72-74]. Secondly, a wireless module and saliva glucose monitoring strip, which are attached to the mouthguard, has also been developed for the detection of the glucose concentration from human saliva [75-79]. The aforementioned two non-invasive glucose sensors not only overcame the painful, time-consuming, and repeated processes, but also achieved the semi-continuous detection of glucose concentration in the human body.

Thirdly, a painless microneedle-type glucose sensor patch has also been developed for the continuous detection of glucose from human physiological fluids merely by attaching the patch to the skin [80-84]. Finally, a stretchable and wearable glucose monitoring patch, which could measure the glucose concentration from human sweat, was developed as the simplest and most painless way for the detection of glucose concentration in the human body [85-89]. Accordingly, with the development of the above-mentioned third and fourth non-invasive glucose sensors, the conventional problems in the invasive glucose sensors, such as the non-user-friendliness and non-continuous detection issues, have been overcome.

Many advantages of the non-invasive glucose sensor devices have been mentioned and explained in this section. However, some of the issues, such as long-term stability, evaluations concerning cytotoxicity, and biocompatibility, have become new challenges in non-invasive glucose sensor devices. Further researches and clinical evaluations should be dealt with prior to the applications to the human body.

\section{Electrochemical Technique for Glucose Sensing}

\subsection{Three-Electrode System of the Electrochemical Technique}

Generally, the electrochemical technique for the detection of glucose concentration is conducted by the three-electrode system, which is composed of (1) a working electrode (WE), (2) a counter electrode (CE), and (3) a reference electrode (RE) [90-92]. For an accurate measurement of the current and potential, the first circuit, which is composed of the WE and the $\mathrm{CE}$, is used for the loop of the current flow. On the other hand, the second circuit, which consists of the WE and the RE, is for the loop of the measurement of the potential between the WE and the RE.

\subsection{Various Measurements via the Electrochemical System for Glucose-Sensing}

With the manipulation of various parameters in the electrochemical techniques, such as current, potential, time, and so forth, a series of electrochemical measurement methods could be realized. For example, cyclic voltammetry (CV), linear sweep voltammetry (LSV), electrochemical impedance spectroscopy (EIS), amperometric response, and other electrochemical techniques are often utilized for the characterization, detection, and quantification of the glucose in the electrolyte. The examples of the aforementioned techniques are shown in Figure 3 [93].

In the case of the CV method (Figure 3a [93]), a specific function of the potential is applied to the aforementioned three-electrode electrochemical system, and the information of the electrochemical reactions in the electrolyte are known by analyzing the corresponding current response. This CV method is considered as a fundamental technique in the electrochemical community and is widely used for investigations of the mechanisms of the electrochemical reactions and the kinetic parameters of electrode processes. In the studies of the glucose sensors, the CV technique is usually utilized for the characterization 
of the glucose-sensing materials, and also for the investigation of the kinetic reactions of the electroactive materials at the WE. In addition, whether the electrochemical reactions belong to diffusion control or reaction control could be recognized by simply alternating the potential scan rate in the CV method.
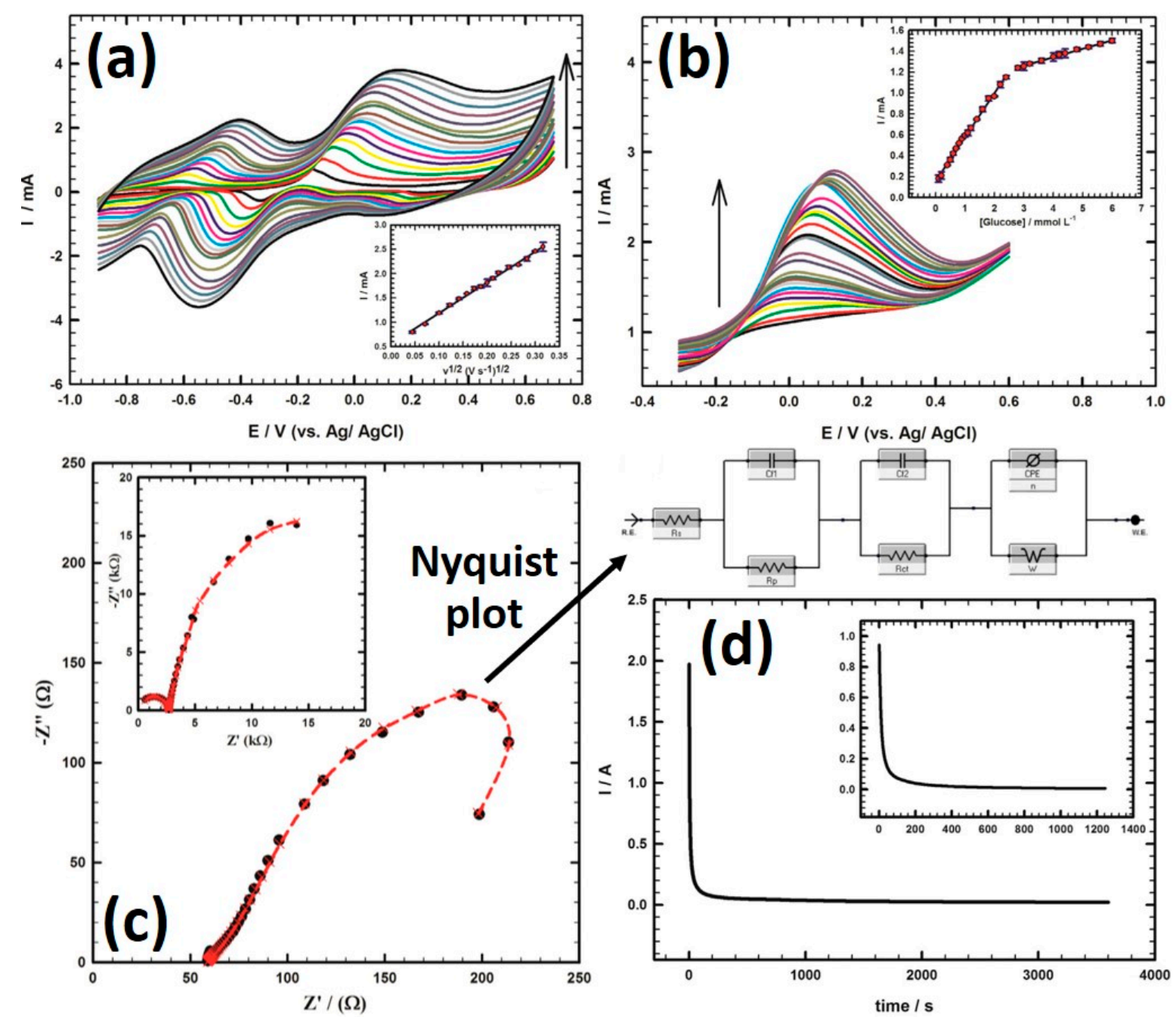

Figure 3. (a) $\mathrm{CVs}$ of $5 \mathrm{mM}$ glucose $/ 0.1 \mathrm{M} \mathrm{NaOH}$ at graphite $/ \mathrm{SrPdO}_{3} / \mathrm{Au}_{\text {nano }}$ electrode at different scan rates $\left(0.002-0.100 \mathrm{~V} \mathrm{~s}^{-1}\right)$ (Inset figure: the plot of the anodic peak current values versus square root of scan rate for $5 \mathrm{mM}$ glucose $/ 0.1 \mathrm{M} \mathrm{NaOH}$ at graphite $/ \mathrm{SrPdO}_{3} / \mathrm{Au}_{\text {nano }}$ electrode) (b) LSVs of $10 \mathrm{~mL}$ of $0.1 \mathrm{M} \mathrm{NaOH}$ at graphite $/ \mathrm{SrPdO}_{3} / \mathrm{Au}_{\text {nano }}$ electrode in different concentrations of glucose $(0.1-6.0 \mathrm{mM}$ ) (Inset figure: calibration curve for glucose for concentrations from 0.1 to $2.4 \mathrm{mM}$ and from 2.8 to $6.0 \mathrm{mM}$ ). (c) Nyquist plot of graphite $/ \mathrm{SrPdO}_{3} / \mathrm{Au}_{\text {nano }}$ electrode and bare graphite (Inset figure: in $5 \mathrm{mM}$ glucose $/ 0.1 \mathrm{M} \mathrm{NaOH}$ at the steady-state potential $(0.100 \mathrm{~V}$ for bare graphite and $0.400 \mathrm{~V}$ for the proposed sensor)). (Black circles represent the experimental measurements and dash red lines with cross symbols represent the computer fitting of impedance spectra). Frequency range: 0.1-100,000 Hz. (d) Chronoamperogram of graphite $/ \mathrm{SrPdO}_{3} / \mathrm{Au}_{\text {nano }}$ electrode at the steady-state potential of glucose $(0.400 \mathrm{~V})$ in $5 \mathrm{mM}$ glucose $/ 0.1 \mathrm{M} \mathrm{NaOH}$ (Inset figure: the same study at the oxidation potential of glucose $(0.050 \mathrm{~V})$ ). (Reproduced with permission from [93]. Copyright Elsevier, 2015).

On the other hand, the LSV method (Figure 3b [93]), which is similar to the CV method, scans the potential monotonically on the WE. With the LSV method, the corresponding polarization current at different potentials could be detected. The Randles-Sevcik equation $[94,95]$, which is used to describe the effect of scan rate on the peak current, is used for the analysis of the LSV method. However, the LSV method is less often conducted for the characterization and investigation of the non-enzymatic glucose sensors compared to the aforementioned $\mathrm{CV}$ method. 
In the case of the EIS method (Figure 3c [93]), the electrochemical impedance is usually measured by applying an AC potential to an electrochemical cell and the corresponding current through the cell is measured. A small sinusoidal potential excitation is often used as the applied AC potential, and the response to this applied potential would be an AC current signal, which can be analyzed as a sum of sinusoidal functions. Therefore, by manipulating the alternating potential of the electrode to make the alternating current change in accordance with the sinusoidal wave function in a small amplitude, the alternating current impedance of the electrode could be measured. The impedance of the examined electrode could be obtained for the determination of its electrical conductivity via the EIS method. The EIS method is usually utilized to characterize the assembly of the sensing materials. Whether the functional materials are properly synthesized on the substrate surface or not could be recognized by this EIS method via the analysis of the change of impedance. The effects of each material on the electrical conductivity of the electrode are also available. Since the impedance also indicates the efficiency of electron transfer, the EIS method could also be a facile method to evaluate the performance of the synthesized sensing electrode.

The amperometric technique (Figure 3d [93]), which is widely used in the field of non-enzymatic glucose-sensing, is based on the measurement of electric current as a function of time $(i-t)$ when a constant electric potential is applied to the electrochemical cell. The dynamic reaction process of the electrode could be obtained via amperometric techniques, which are frequently utilized for the examination of various performances of the glucose-sensing materials. Firstly, for example, the sensitivity of the sensing material could be investigated by continuously introducing glucose into the electrochemical cell while maintaining the potential of the WE at a specific constant potential. Secondly, the selectivity of the sensing materials could also be analyzed by reading the corresponding responses caused by the introduction of glucose and interfering molecules into the electrochemical cell. Thirdly, the response time could also be determined by reading the current plateau after introducing glucose molecules into the electrolyte. Lastly, further analysis could also be achieved by the amperometric technique, which is considered a promising method for the investigation and examination of the non-enzymatic glucose sensor.

\section{Mechanisms for Glucose-Sensing in Non-Enzymatic Electrodes}

The fundamental concept for glucose-sensing is the electro-oxidation reactions of glucose on the electroactive materials, which are synthesized on the electrode substrate. Hence, the flow of the electrons from the glucose to the external circuit is detected [96-98]. In the case of the enzymatic glucose sensors, enzymes, such as GOx or GDH, play an important role in the aforementioned oxidation of glucose [99-101]. On the other hand, in the case of the non-enzymatic glucose sensor, non-organic materials, such as metals, alloys, and / or their derivatives (i.e., oxides, hydroxides, etc.), trigger the oxidation reactions of glucose [34-46].

The mechanisms for the non-enzymatic glucose sensor could be generally classified into two different manners. The first model, which is known as the "Activated Chemisorption Model", was proposed by Pletcher [102] in 1984. An illustration of the mechanism is shown in Figure 4. Here, $C_{1}$ indicates the hemiacetalic carbon atom, while R suggests the remaining part of the glucose molecule. 


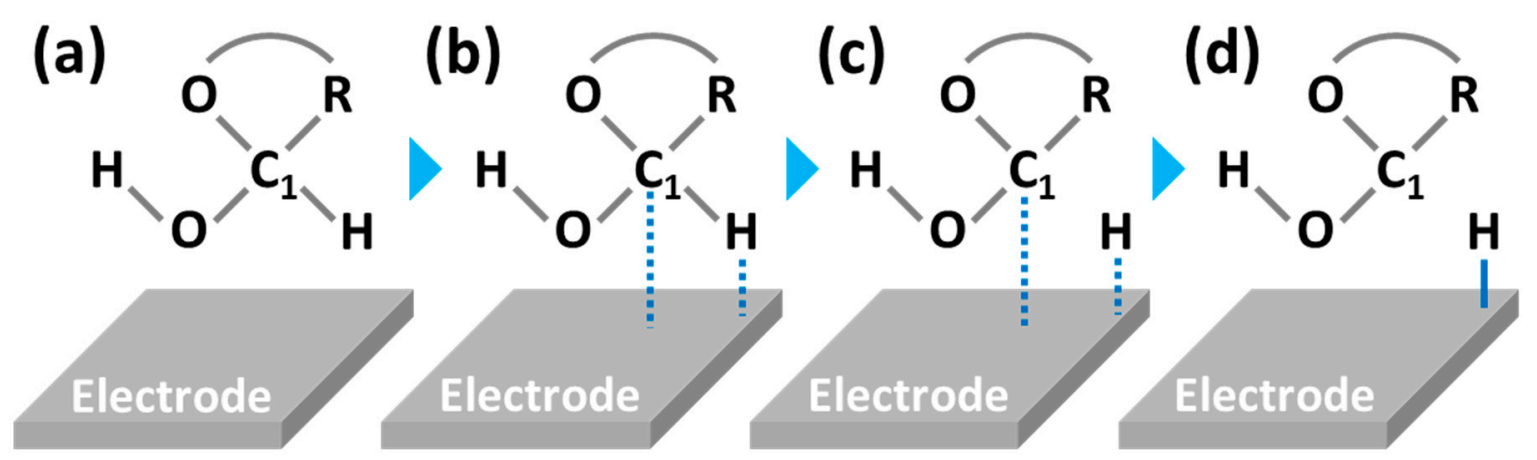

Figure 4. An illustration for the "activated chemisorption model (first model for the non-enzymatic glucose sensor)", which includes (a) adsorption, (b) bond formation, (c) bond breaking, and (d) desorption processes between the glucose molecule and the electrode surface. $\left(C_{1}\right.$ : hemiacetalic carbon atom; $R$ : the remaining parts of the glucose molecule; dotted lines: relatively weak bonding; solid lines: relatively strong bonding).

\subsection{Activated Chemisorption Model (First Model)}

In the case of the "activated chemisorption model", it was claimed that the oxidation reaction of glucose molecule is firstly initiated through the adsorption of the glucose on the surface of the electrode (Figure 4a), which is an electroactive material. Secondly, a weak bonding between the glucose molecule and the substrate surface (dotted blue line) is formed. Meanwhile, the hydrogen atom in the glucose molecule, which is connected to the hemiacetal carbon, is extracted (dotted blue line) (Figure $4 \mathrm{~b}$ ). Thirdly, after the weak bonding between the hemiacetal carbon and the electrode surface as well as the weak bonding between the hydrogen atom and the electrode surface are both formed (dotted blue lines), the bonding between the hemiacetal carbon and the hydrogen atom is broken (Figure 4c). Finally, desorption of the dehydrogenated glucose takes place since there is a change in the oxidation state of the glucose molecule, and the glucose-metal bond strength is mitigated (Figure 4d). Since the adsorption (formation of bond) and the desorption (breaking of bond) take place in the overall reactions, the moderate bonding strength between the glucose molecule and the surface of the electrode material is favored.

\subsection{Incipient Hydrous Oxide Adatom Mediator (IHOAM) (Second Model)}

The second model, which was reported by Burke [103] in 1994, is known as the "incipient hydrous oxide adatom mediator (IHOAM) model". It was claimed that the reactivity of the electroactive material on the electrode surface could be attributed to its low lattice stabilization [103-105]. The hydroxide ion $\left(\mathrm{OH}^{-}\right)$in the electrolyte adsorbs on the electrode (i.e., metallic electrode) forming an incipient hydrous oxide $\left(\mathrm{M}-\mathrm{OH}_{\mathrm{ads}}\right)$, which is believed to be the crucial mediator for the electro-oxidation reactions of glucose molecule in the electrolyte. The glucose molecule is thereafter oxidized by the $\mathrm{M}-\mathrm{OH}_{\mathrm{ads}}$ mediator, while the $\mathrm{M}-\mathrm{OH}_{\mathrm{ads}}$ is transformed back to its metallic state. Therefore, the overall reactions could be divided into the oxidation reaction (red area on the left side) and the reduction reaction (blue area on the right side), which are shown in Figure 5. Glucose molecules are oxidized in the red area (left side), the oxidation-reduction reactions are repeatedly cycled in the electroactive materials (middle), and the corresponding reduction reactions are shown in the blue area (right side). 


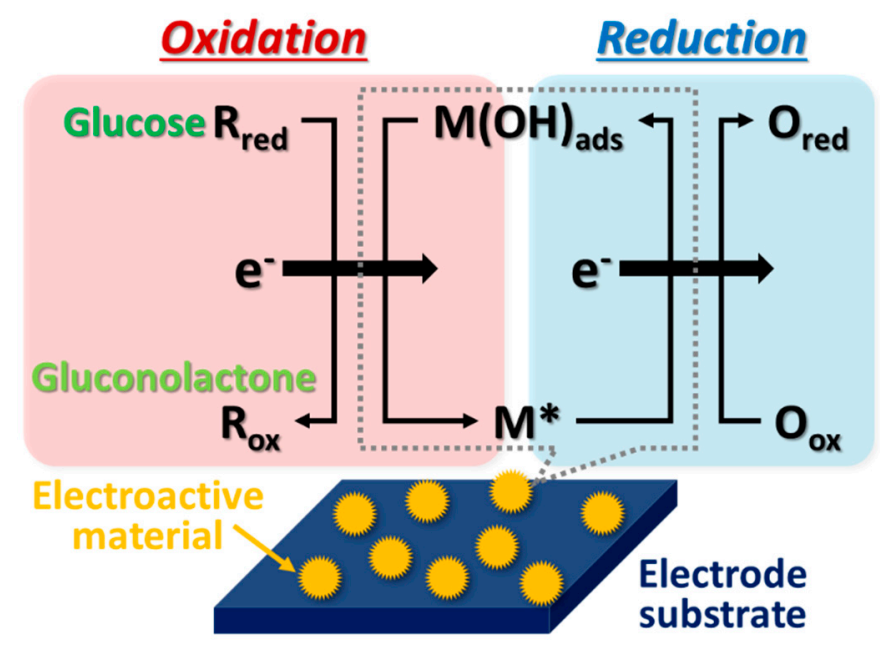

Figure 5. An illustration for the overall reactions of the glucose-sensing by the mechanism of the Incipient Hydrous Oxide Adatom Mediator (IHOAM) on non-enzymatic electrodes.

\section{Systems of Electroactive Materials for the Sensing of Glucose}

An illustration for the classification of the active materials in the glucose-sensing electrode is shown in Figure 6. Firstly, proper substrates for the synthesis of the active materials were chosen (Figure 6a). Metallic substrates, such as Ni [37], Cu [106], Pt [107], $\mathrm{Au}$ [108], and alloys [109], are often utilized, while other non-metallic substrates, such as indium-tin-oxide (ITO) [110] and glassy carbon (GC) [34], are also other choices. Some of the substrates themselves (i.e., $\mathrm{Pt}, \mathrm{Au}$, and so forth) possess an electroactivity to the sensing of glucose via electrochemical techniques. The electrocatalytic activity of the substrate could be further improved by decorating the specific substrates with high electroactive materials. It is also known that the crystal orientation affects the performances of the electrodes [34,107]. Therefore, the selection of substrates for the growth of crystalline materials could be a critical issue.

Secondly, for the purposes of the high surface area, supporting, and stability, supporting materials are usually fabricated for the enhancement of the performances of the electroactive materials (Figure 6b). The carbon-based materials, such as graphene sheets [111], graphene oxide (GO) [112], reduced graphene oxide (rGO) [113,114], and carbon nanobased materials [115-118], are frequently used. Electrically conductive polymers, such as polyaniline (PANI) [119,120] and polypyrrole (PPy) [121] are also promising candidates for the supporting materials due to their low cost, large surface area, and manipulatable properties by functionalization treatments [122]. On the other hand, inorganic materials, such as $\mathrm{TiO}_{2}$ nanotube array [123] and the $\mathrm{CoOOH}$ nanosheets [124], are also widely utilized. In some of the studies, the substrate and the supporting material were not thoroughly independent. Instead, the substrates and the supporting materials could be identical material.

The aforementioned substrates and supporting materials were classified as the "auxiliary materials" in Figure 6a,b. Meanwhile, the "electroactive materials", which are listed and discussed in the following sections, were categorized into five major different types in Figure $6 c-g$. Finally, the crucial materials, which determine the performance of the glucosesensing electrodes, would be the electroactive materials (Figure $6 c-g$ ). There are many types of electroactive material for the sensing of glucose by the electrochemical methods, such as (1) metal materials and (2) alloy materials [34-37,48-50,53,61,125-132] (Figure 6c,d), (3) oxide materials and (4) hydroxide materials [39,40,51,52,54,55,58,59,64-66,133-139] (Figure 6e,f), as well as (5) composite materials [38,42-47,56,57,62,63,67,140-144] (Figure 6g). In this review article, the sensing materials, performances, and mechanisms of the aforementioned five major types of classifications are described separately in the following sections. 


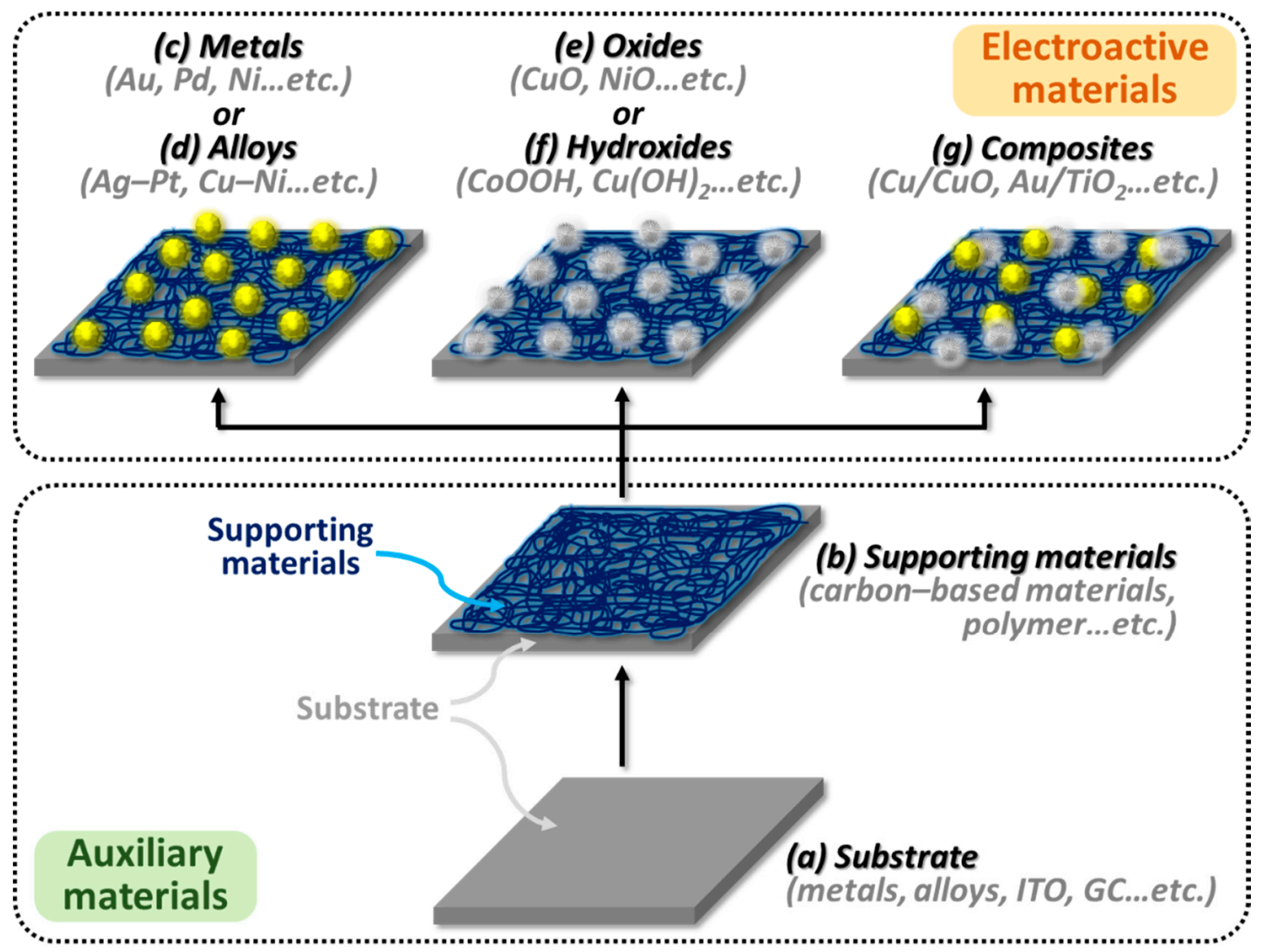

Figure 6. Illustration of the sensing electrodes for glucose. (a) Substrate materials and (b) supporting materials are classified into the "Auxiliary materials (bottom dotted square)". (c) Metals, (d) alloys, (e) oxides, (f) hydroxides, and (g) composites are categorized into the "Electroactive materials (top dotted square)" for playing the role of catalysts in glucose-sensing.

\section{Electroactive Materials of Mono-Metallic Materials}

\subsection{Crystal Structure Controlled Pd Nanocubes}

The mono-metallic materials are considered to be the simplest materials for the electrooxidation of glucose. It is widely known that the electroactivity alters with the crystalline planes [145-152]. For the effective utilization of the electrocatalytic activity of the electroactive materials, controlling the growth of the crystalline for promoting the electrocatalytic activity has attracted much attention. Ye et al. [34] worked on a comparison between the uncontrolled polyhedral Pd nanoparticles (PdNPs) and the controlled mono-metallic Pd nanocubes (PdNCs) with (100) plane.

Figure 7 shows the TEM images of morphologies and crystalline of (a) the PdNCs and (b) the PdNPs. It is observed that the PdNCs possessed a cubic structure (Figure 7a), while the PdNPs (Figure $7 b$ ) demonstrate a polygonal structure.

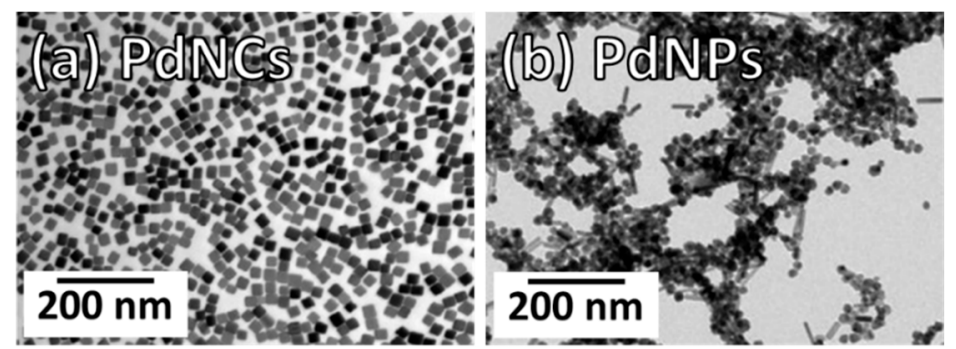

Figure 7. TEM images of (a) the PdNCs and (b) the PdNPs for morphology observations. (Reproduced with permission from [34]. Copyright Elsevier, 2015). 
Figure 8 shows the $\mathrm{CV}$ measurements for the explanation of the mechanisms of the PdNCs and the PdNPs. Since glucose was not introduced into the $0.1 \mathrm{M} \mathrm{NaOH}$ electrolyte in the CV measurement in Figure 8a, merely the reduction and oxidation reactions of the PdNCs and the PdNPs electrodes could be observed in the CV curves. At peak R1 in the negative scan $(E=-0.76 \mathrm{~V}$ vs. $\mathrm{Ag} / \mathrm{AgCl})$ (Figure 8a), the reduction peak indicated the chemical adsorption reaction of hydrogen on the metallic Pd surface (Equation (1)) [34], which could be expressed by

$$
\mathrm{Pd}+\mathrm{H}_{2} \mathrm{O}+\mathrm{e}^{-} \rightarrow \mathrm{Pd}-\mathrm{H}_{\mathrm{ads}}+\mathrm{OH}^{-}
$$

On the other hand, in the positive sweep, the oxidation peak $\mathrm{O} 1$ at approximately $-0.8 \mathrm{~V}$ can be ascribed to the oxidation of the hydrogen atoms, which adsorbed on $\mathrm{Pd}$ in the negative scan [153]. This could be expressed by Equation (2):

$$
\mathrm{Pd}-\mathrm{H}_{\mathrm{ads}}+\mathrm{OH}^{-} \rightarrow \mathrm{Pd}+\mathrm{H}_{2} \mathrm{O}+\mathrm{e}^{-}
$$

With the increment of the scanning potential in the positive sweep, a small oxidation peak at approximately $-0.42 \mathrm{~V}$ (peak O2) could be assigned to the desorption of the absorbed $\mathrm{H}$ atoms, which diffused from the inner part of Pd to the surface of $\mathrm{Pd}$ [154]. Continuous oxidation reactions, which took place, with the increment of the potential from $-0.28 \mathrm{~V}$ to $0.25 \mathrm{~V}$ (oxidation reaction of $\mathrm{O} 3$ ), could be attributed to the following three reactions (Equations (3)-(5)) [155]

$$
\begin{gathered}
\mathrm{Pd}+\mathrm{OH}^{-} \rightarrow \mathrm{Pd}-\mathrm{OH}_{\mathrm{ads}}+\mathrm{e}^{-} \\
\mathrm{Pd}-\mathrm{OH}_{\mathrm{ads}}+\mathrm{OH}^{-} \rightarrow \mathrm{Pd}-\mathrm{O}+\mathrm{H}_{2} \mathrm{O}+\mathrm{e}^{-} \\
\mathrm{Pd}-\mathrm{OH}_{\mathrm{ads}}+\mathrm{Pd}-\mathrm{OH}_{\mathrm{ads}} \rightarrow \mathrm{Pd} \text { oxides }+\mathrm{H}_{2} \mathrm{O}
\end{gathered}
$$

Lastly, the electro-reduction reaction, which occurred at approximately $-0.24 \mathrm{~V}$ (peak $\mathrm{R} 2$ ) in the negative scan, could correspond to the electro-reduction reaction of the Pd-oxide film on the Pd nanomaterials $[156,157]$.
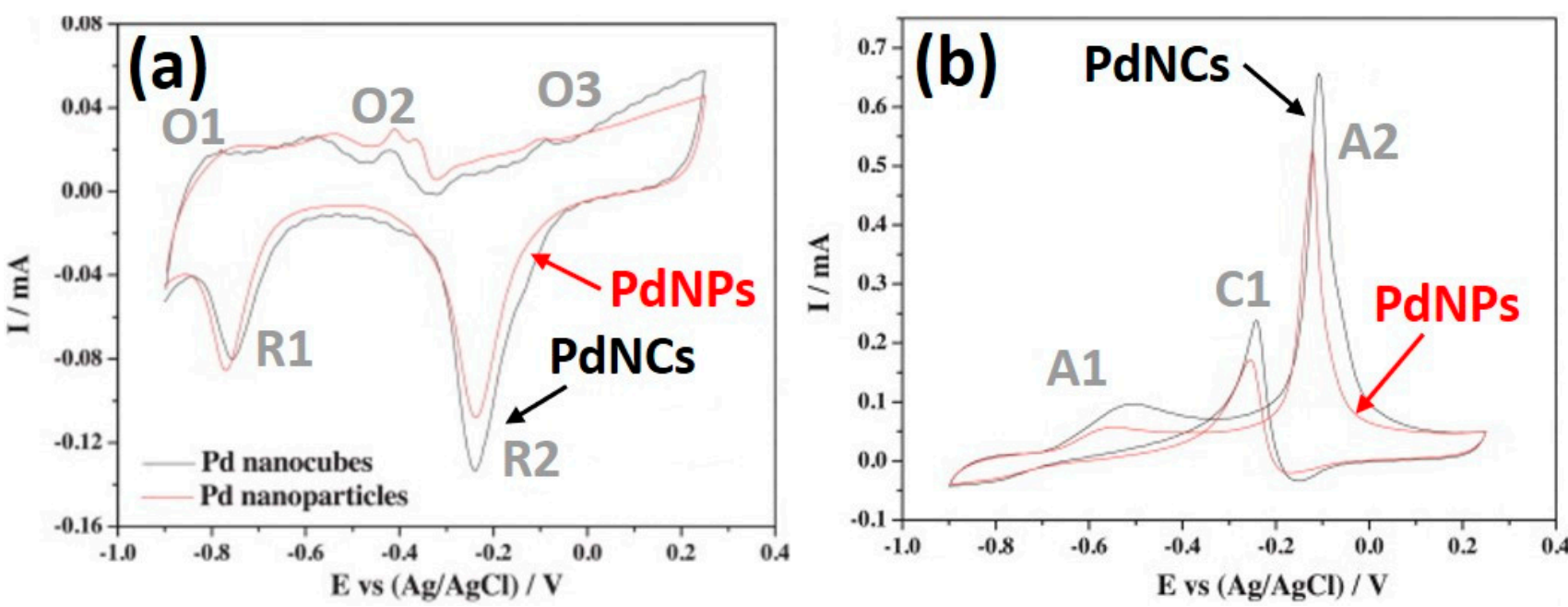

Figure 8. $\mathrm{CV}$ curves of the PdNCs and the PdNPs in a $\mathrm{N}_{2}$-saturated $0.1 \mathrm{M} \mathrm{NaOH}$ electrolyte, which was (a) without the introduction of $5 \mathrm{mM}$ glucose and (b) with the introduction of $5 \mathrm{mM}$ glucose. (Black curves: PdNCs; Red curves: PdNPs; " $\mathrm{O}$ " and " $\mathrm{A}$ " symbols: reactions occurred in the positive scan (forward scan); " $\mathrm{R}$ " and " $\mathrm{C}$ " symbols: reactions took place in the negative scan (backward scan)). (Reproduced with permission from [34]. Copyright Elsevier, 2015).

Figure $8 \mathrm{~b}$ shows the results of the current responses of the PdNCs (black curve) and the PdNPs (red curve) electrodes under a certain potential range in $5 \mathrm{mM}$ glucose in $0.1 \mathrm{mM}$ $\mathrm{NaOH}$ solution. Two anodic peaks (i.e., A1 and A2) were observed in the positive sweep 
of the CV method. Oxidation peak A1 indicates the electro-adsorption of glucose to the surface of the Pd nanomaterials along with a release of one proton per glucose molecule, which becomes to the Pd-glucose ${ }_{\text {ads }}$ intermediate $[158,159]$. The reaction equation could be described in Equation (6):

$$
\mathrm{Pd}+\text { Glucose } \rightarrow \mathrm{Pd}-\text { Glucose }_{\mathrm{ads}}+\mathrm{H}^{+}+\mathrm{e}^{-}
$$

With a further increment of the sweeping potential, another A2 oxidation peak is observed at approximately $-0.11 \mathrm{~V}$ in the positive scan. This oxidation reaction could be attributed to the following reaction $[49,160]$, which is expressed by Equation (7):

$$
\mathrm{Pd}-\mathrm{OH}+\text { Glucose } \rightarrow \mathrm{Pd}+\text { Gluconolactone }
$$

The Pd-OH intermediate in Equation (7) was the electroactive site for the electrooxidation of glucose. It has also been reported that the product after the electrochemical glucose oxidation on the Pd electrode would be gluconolactone [161]. Therefore, the gluconolactone was assigned to Equation (7). According to Equation (7), the large A2 oxidation peak could be considered as a criterion for the comparison of the electroactivity of the PdNCs and the PdNPs. An enhanced current in the PdNCs indicated the promoted electrocatalytic activity of the PdNCs than the PdNPs.

On the other hand, in the negative scan, the glucose in the electrolyte was oxidized immediately upon the reduction reaction from the palladium oxide (i.e., $\mathrm{PdO}$ ) to the metallic $\mathrm{Pd}$ (i.e., $\mathrm{Pd}$ nanomaterials). Therefore, the $\mathrm{C} 1$ peak was a combination of the aforementioned two reactions (i.e., the reduction reaction of PdO and Equation (7)) [158].

\subsection{Mechanisms and Comparisons of the Mono-Metallic Materials}

The aforementioned mechanisms for the series of the electro-oxidation of glucose by the Pd nanomaterials could also be applied to other mono-metallic materials, such as the Au micropillar array [162], Au nanoparticles [163], Pt nanoparticles [164], Co-based metal-organic framework (Co-MOF) [165], Co-phosphate nanomaterials [166], Cu-based metal-organic framework (Cu-MOF) [167], Cu nanoflowers [168], porous Ni foam [169], and $\mathrm{Ni}$ nanowire array [170]. Generally, the noble metals, such as $\mathrm{Au}, \mathrm{Pd}$, and $\mathrm{Pt}$, are used in their metallic state while the transition metals, such as $\mathrm{Co}, \mathrm{Cu}$, and $\mathrm{Ni}$, are mostly used in their oxidation forms, which are discussed in the following sections. The mechanisms of the frequently seen mono-metallic (a) Au [162,163], (b) Pd [34,171], (c) Pt [164], (d) Co $[110,165,166]$, (e) Cu $[167,168]$, and (f) Ni $[169,170]$ materials are summarized in Table 1. Besides, the general reaction mechanisms for the formation of the electroactive intermediates and the electro-oxidation of glucose are also shown and compared in Table $1 \mathrm{~g}$.

In Table 1, it can be found that, although there are some differences among the formation of the electroactive intermediates, the general chemical reaction is the oxidation of the metals from their metallic state to the oxidized state, which could be the metal-oxide and/or the metal-hydroxide compounds. Besides the reaction from the metallic form to the oxidized form, some of the metal-oxide and/or the metal-hydroxide compounds could be further oxidized into their high oxidation state. For example, $\mathrm{CuO}$ could be further oxidized into $\mathrm{CuOOH}$ or $\mathrm{Cu}(\mathrm{OH})_{4}{ }^{-}$compounds [167,168], while $\mathrm{NiO}$ and $\mathrm{Ni}(\mathrm{OH})_{2}$ could be further oxidized to the $\mathrm{NiOOH}$ compound [169,170]. In the case of $\mathrm{Cu}$, the electroactive intermediate for glucose oxidation would be the $\mathrm{Cu}$ (III) molecules. Similarly, the electroactive intermediate would be the $\mathrm{Ni}(\mathrm{III})$ in the case of $\mathrm{Ni}$. Again, the oxidized transition metals, such as $\mathrm{Co}_{3} \mathrm{O}_{4}, \mathrm{CuO}, \mathrm{Fe}_{2} \mathrm{O}_{3}, \mathrm{NiO}$, and so forth, which were often utilized as the electrocatalyst directly due to the stability issues, are discussed in Sections 8 and 9.

It was also found that the products could vary while the electroactive materials altered. For example, gluconolactone was obtained as the product when the electroactive materials are $\mathrm{Au}, \mathrm{Pd}, \mathrm{Pt}, \mathrm{Co}$, and $\mathrm{Ni}$, while gluconic acid has been claimed as the product when $\mathrm{Cu}$ was used as the electroactive material. 
Table 1. The formation mechanisms of the electroactive intermediates and the electro-oxidation of glucose in the alkaline solution by the electroactive materials of the mono-metallic (a) Au [162,163], (b) Pd [34,171], (c) Pt [164], (d) Co [110,165,166], (e) $\mathrm{Cu}[167,168]$, and (f) Ni $[169,170]$. The general mechanisms for the formation of the electroactive intermediates and the electro-oxidation of glucose in the alkaline solution are also summarized and shown in (g).

Electrodes

(a) $\mathrm{Au}$

$[162,163]$

\section{Chemical Reactions and Mechanisms}

- Formation of electroactive intermediate

$\mathrm{Au}+\mathrm{OH}^{-} \rightarrow \mathrm{Au}-\mathrm{OH}_{\mathrm{ads}}+\mathrm{e}^{-}$

$\bullet \quad$ Electro-oxidation of glucose
$\mathrm{Au}-\mathrm{OH}_{\mathrm{ads}}+$ Glucose $\rightarrow \mathrm{Au}+$ Gluconolactone

- Formation of electroactive intermediate: step $1(\operatorname{Pd}(0)) \rightarrow \operatorname{Pd}(\mathrm{I}))$

$\mathrm{Pd}+\mathrm{OH}^{-} \rightarrow \mathrm{Pd}-\mathrm{OH}_{\mathrm{ads}}+\mathrm{e}^{-}$

(b) Pd

$[34,171]$

- Electrooxidation reaction of $\mathrm{Pd}$ : step $2(\mathrm{Pd}(\mathrm{I})) \rightarrow \mathrm{Pd}(\mathrm{II})$ )

$$
\mathrm{Pd}-\mathrm{OH}_{\mathrm{ads}}+\mathrm{Pd}-\mathrm{OH}_{\mathrm{ads}} \rightarrow \text { Pd oxides }+\mathrm{H}_{2} \mathrm{O}
$$

- Electro-oxidation of glucose

$\mathrm{Pd}-\mathrm{OH}_{\mathrm{ads}}+$ Glucose $\rightarrow \mathrm{Pd}+$ Gluconolactone

- Electro-oxidation reaction of Pt: step $1(\mathrm{Pt}(0) \rightarrow \mathrm{Pt}(\mathrm{II}))$

(c) $\mathrm{Pt}$ $\mathrm{Pt}+2 \mathrm{OH}^{-} \rightarrow \mathrm{Pt}(\mathrm{OH})_{2}+2 \mathrm{e}^{-}$

[164]

- Formation of electroactive intermediate: step $2(\mathrm{Pt}(\mathrm{II}) \rightarrow \mathrm{Pt}(\mathrm{IV}))$

$\mathrm{Pt}(\mathrm{OH})_{2}+2 \mathrm{OH}^{-} \rightarrow \mathrm{PtO}(\mathrm{OH})_{2}+\mathrm{H}_{2} \mathrm{O}+2 \mathrm{e}^{-}$

$\mathrm{PtO}(\mathrm{OH})_{2}+$ Glucose $\rightarrow \mathrm{Pt}(\mathrm{OH})_{2}+$ Gluconolactone

- Electro-oxidation reaction of $\mathrm{Co}$ : step $1(\mathrm{Co}(0) \rightarrow \mathrm{Co}(\mathrm{II}))$

$$
\mathrm{Co}+2 \mathrm{OH}^{-} \rightarrow \mathrm{Co}(\mathrm{OH})_{2}+2 \mathrm{e}^{-}
$$

- Formation of electroactive intermediate: step 2 (Co(II) $\rightarrow \mathrm{Co}(\mathrm{III}))$

(d) $\mathrm{Co}$

$[110,165,166]$

$$
\mathrm{Co}(\mathrm{OH})_{2}+\mathrm{OH}^{-} \rightarrow \mathrm{CoOOH}+\mathrm{H}_{2} \mathrm{O}+\mathrm{e}^{-}
$$

- Formation of electroactive intermediate: step $3(\mathrm{Co}(\mathrm{III}) \rightarrow \mathrm{Co}(\mathrm{IV}))$

$\mathrm{CoOOH}+\mathrm{OH}^{-} \rightarrow \mathrm{CoO}_{2}+\mathrm{H}_{2} \mathrm{O}+\mathrm{e}^{-}$

- Electro-oxidation of glucose

$\mathrm{CoOOH}+$ Glucose $\rightarrow \mathrm{Co}(\mathrm{OH})_{2}+$ Gluconolactone or

$\mathrm{CoO}_{2}+$ Glucose $\rightarrow \mathrm{CoOOH}+$ Gluconolactone

- Electro-oxidation reaction of $\mathrm{Cu}$ : step $1(\mathrm{Cu}(0) \rightarrow \mathrm{Cu}(\mathrm{II}))$

$$
\mathrm{Cu}+2 \mathrm{OH}^{-} \rightarrow \mathrm{CuO}+\mathrm{H}_{2} \mathrm{O}+2 \mathrm{e}^{-}
$$

or

$$
\mathrm{Cu}+2 \mathrm{OH}^{-} \rightarrow \mathrm{Cu}(\mathrm{OH})_{2}+2 \mathrm{e}^{-}
$$

(e) $\mathrm{Cu}$

$[167,168]$

- Formation of electroactive intermediates: step $2(\mathrm{Cu}(\mathrm{II}) \rightarrow \mathrm{Cu}(\mathrm{III}))$

$$
\mathrm{CuO}+\mathrm{OH}^{-} \rightarrow \mathrm{CuOOH}+\mathrm{e}^{-}
$$

$$
\text { or }
$$

$$
\mathrm{CuO}+\mathrm{H}_{2} \mathrm{O}+2 \mathrm{OH}^{-} \rightarrow \mathrm{Cu}(\mathrm{OH})_{4}^{-}+\mathrm{e}^{-}
$$

- Electro-oxidation of glucose

$\mathrm{Cu}(\mathrm{III})+$ Glucose $\rightarrow \mathrm{Cu}(\mathrm{II})+$ Gluconic acid

- Electro-oxidation reaction of Ni: step $1(\mathrm{Ni}(0) \rightarrow \mathrm{Ni}(\mathrm{II}))$

$$
\begin{aligned}
& \mathrm{Ni}+2 \mathrm{OH}^{-} \rightarrow \mathrm{NiO}+\mathrm{H}_{2} \mathrm{O}+2 \mathrm{e}^{-} \\
& \text {or } \\
& \mathrm{Ni}+2 \mathrm{OH}^{-} \rightarrow \mathrm{Ni}(\mathrm{OH})_{2}+2 \mathrm{e}^{-}
\end{aligned}
$$

(f) $\mathrm{Ni}$

$[169,170]$
- Formation of electroactive intermediates: step 2 (Ni(II) $\rightarrow \mathrm{Ni}(\mathrm{III})$ )

$$
\begin{aligned}
& \mathrm{NiO}+\mathrm{OH}^{-} \rightarrow \mathrm{NiOOH}+\mathrm{e}^{-} \\
& \text {or } \\
& \mathrm{Ni}(\mathrm{OH})_{2}+\mathrm{OH}^{-} \rightarrow \mathrm{NiOOH}+\mathrm{H}_{2} \mathrm{O}+\mathrm{e}^{-}
\end{aligned}
$$

- Electro-oxidation of glucose $\mathrm{NiOOH}+$ Glucose $\rightarrow \mathrm{Ni}(\mathrm{OH})_{2}+$ Gluconolactone 
Table 1. Cont

\begin{tabular}{|c|c|}
\hline Electrodes & Chemical Reactions and Mechanisms \\
\hline & $\begin{array}{l}\text { Formation of electroactive intermediates } \\
\mathrm{M}(\mathrm{LOS})+\mathrm{OH}^{-} \rightarrow \mathrm{M}(\mathrm{MOS})+\mathrm{e}^{-} \\
\text {and } / \text { or } \\
\mathrm{M}(\mathrm{MOS})+\mathrm{OH}^{-} \rightarrow \mathrm{M}(\mathrm{HOS})+\mathrm{e}^{-}\end{array}$ \\
\hline (g) General & $\begin{array}{c}\bullet \text { Electro-oxidation of glucose } \\
\mathrm{M}(\mathrm{HOS})+\text { Glucose } \rightarrow \mathrm{M}(\mathrm{LOS})+\text { Products } \\
\text { where } \\
\mathrm{M}=\text { Mono-metal } \\
\text { LOS = Low oxidation state } \\
\mathrm{MOS}=\text { Medium oxidation state } \\
\text { HOS = High oxidation state } \\
\text { Products = Glucose derivatives }\end{array}$ \\
\hline
\end{tabular}

In Section 6.1, the mechanisms for the series of the electro-oxidation of the glucose in the alkaline solution by the Pd nanomaterials [34] are reviewed. In addition, the similar mechanisms of the noble metals and the transition metals in their mono-metallic forms are also listed, summarized, and compared [34,110,162-170]. A general reaction mechanism was summarized and expressed in Table 1g. Moreover, the performances of the nonenzymatic glucose sensors, which were composed of the noble metals (i.e., $\mathrm{Au}, \mathrm{Pd}$, and $\mathrm{Pt}$ ) and transition metals (i.e., $\mathrm{Co}, \mathrm{Cu}$, and $\mathrm{Ni}$ ), within this decade are listed and compared in Tables 2 and 3, respectively. Here, it was found that although the transition metal series performed relatively high sensitivity, the operation potential is three times higher than that of the noble metals. The average operation potential of the transition metal series (Table 3) is $0.54 \mathrm{~V}$ (with respect to $\mathrm{Ag} / \mathrm{AgCl}$ ), while the average operation potential of the noble metal series (Table 2) is $0.17 \mathrm{~V}$. One could also discover that the linear range of the transition metal series is narrower than that of the noble metal series. For balancing the various performances, such as sensitivity, linear range, limit of detection (LOD), and other behaviors, bi-metallic electrodes have been also widely studied. The bi-metallic (alloy) electrodes are reviewed in Section 7.

Table 2. Electrodes for the sensing of glucose by the noble mono-metallic (a) Au, (b) Pd, and (c) Pt materials within this decade. The performances are compared in terms of sensitivity, linear range, limit of detection (LOD), and working potential. The working potentials were based on the reference electrode of $\mathrm{Ag} / \mathrm{AgCl}$.

\begin{tabular}{|c|c|c|c|c|c|}
\hline $\begin{array}{c}\text { Electrode } \\
{[\text { Electrolyte] }}\end{array}$ & 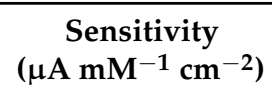 & $\begin{array}{c}\text { Linear } \\
\text { Range }(\mathrm{mM})\end{array}$ & $\operatorname{LOD}(\mu \mathrm{M})$ & $\begin{array}{c}\text { Working } \\
\text { Potential (V) * }\end{array}$ & $\begin{array}{c}\text { Year } \\
\text { [Reference] }\end{array}$ \\
\hline \multicolumn{6}{|c|}{ (a) Mono-metallic Au electrodes } \\
\hline $\begin{array}{c}\text { Dendrite } \mathrm{Au} / \text { paper fiber } \\
{[0.1 \mathrm{M} \mathrm{NaOH}]}\end{array}$ & 30.0 & $0.01-15$ & 0.6 & +0.60 & 2020 [172] \\
\hline $\begin{array}{c}\mathrm{Au} \text { NP/N-doped GCNTs/GCE } \\
{[0.1 \mathrm{M} \mathrm{NaOH}]}\end{array}$ & 0.98 & $0.002-19.6$ & 0.5 & +0.20 & 2018 [173] \\
\hline $\begin{array}{c}\text { Mesoporous } \mathrm{Au} / \mathrm{Au}-\mathrm{Si} \text { electrode } \\
{[0.1 \mathrm{M} \mathrm{NaOH}]}\end{array}$ & 291.6 & $0.0-10$ & 4.13 & +0.20 & 2017 [174] \\
\hline $\begin{array}{c}\mathrm{Au} \text { NPs-MWCNTs/AuE } \\
{[0.05 \mathrm{M} \mathrm{NaOH}]}\end{array}$ & 27.7 & $0.001-1.0$ & 0.5 & +0.20 & 2017 [116] \\
\hline $\begin{array}{l}\text { Au nanocages/GCE } \\
{[0.2 \mathrm{M} \mathrm{NaOH}]}\end{array}$ & 2131 & $1-9$ & 100 & - & 2016 [175] \\
\hline $\begin{array}{c}\text { Pine-like nano-Au/AuE } \\
{[0.1 \mathrm{M} \mathrm{NaOH}]}\end{array}$ & 776.9 & $0.02-0.24$ & 3.39 & +0.07 & $2016[176]$ \\
\hline $\begin{array}{l}\mathrm{Au} \mathrm{NPs} / \mathrm{GCE} \\
{[1 \mathrm{M} \mathrm{NaOH}]}\end{array}$ & 87.5 & $0.1-25$ & 50 & +0.24 & 2014 [177] \\
\hline
\end{tabular}


Table 2. Cont.

\begin{tabular}{|c|c|c|c|c|c|}
\hline $\begin{array}{c}\text { Electrode } \\
\text { [Electrolyte] }\end{array}$ & 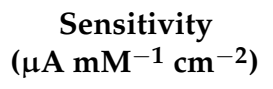 & $\begin{array}{c}\text { Linear } \\
\text { Range }(\mathrm{mM})\end{array}$ & LOD $(\mu \mathrm{M})$ & $\begin{array}{c}\text { Working } \\
\text { Potential (V) * }\end{array}$ & $\begin{array}{c}\text { Year } \\
\text { [Reference] }\end{array}$ \\
\hline $\begin{array}{l}\mathrm{Au} \text { NPs/GCE } \\
{[1 \mathrm{M} \mathrm{NaOH}]}\end{array}$ & 87.5 & $0.1-25$ & 50 & +0.24 & 2014 [177] \\
\hline $\begin{array}{l}\text { Au NPs-GO nanoribbons/Carbon sheet } \\
\text { [0.1 M PBS] }\end{array}$ & $\begin{array}{l}59.1 \\
31.4\end{array}$ & $\begin{array}{c}0.005-4.92 \\
4.92-10\end{array}$ & 5 & +0.20 & 2014 [178] \\
\hline $\begin{array}{l}\text { Nano Au-CNTs/GCE } \\
{[0.01 \mathrm{M} \text { PBS] }}\end{array}$ & 25 & $0-50$ & 100 & +0.39 & 2014 [179] \\
\hline $\begin{array}{l}\text { Au MPA/Si } \\
{[0.01 \mathrm{M} \text { PBS] }}\end{array}$ & 13.2 & $0.5-9$ & 60 & - & 2012 [162] \\
\hline \multicolumn{6}{|c|}{ (b) Mono-metallic Pd electrodes } \\
\hline $\begin{array}{l}\text { PBTh-Pd particles/ITO } \\
{[0.1 \mathrm{M} \mathrm{NaOH}]}\end{array}$ & 5620 & $0.04-0.4$ & 7 & +0.60 & $2020[180]$ \\
\hline $\begin{array}{c}\text { Pd NPs-GN-MWCNTs/GCE } \\
{[0.1 \mathrm{M} \mathrm{NaOH}]}\end{array}$ & $\begin{array}{l}83.0 \\
52.9\end{array}$ & $\begin{array}{c}0.025-10 \\
10-100\end{array}$ & 8 & -0.1 & 2019 [181] \\
\hline $\begin{array}{c}\text { GO-PAA-Pd NPs/SPCE } \\
{[0.1 \mathrm{M} \mathrm{NaOH}]}\end{array}$ & $\begin{array}{l}75 \\
37\end{array}$ & $\begin{array}{c}0.05-15 \\
15-60\end{array}$ & 22 & -0.1 & 2019 [171] \\
\hline $\begin{array}{l}\text { Pd NPs-CSP/GCE } \\
{[0.1 \mathrm{M} \mathrm{NaOH}]}\end{array}$ & 17.7 & $1-8$ & 237 & -0.05 & 2018 [182] \\
\hline $\begin{array}{l}\text { Pd NPs-halloysite nanotubes/GCE } \\
\qquad[0.1 \mathrm{M} \mathrm{NaOH}]\end{array}$ & $\begin{array}{c}362.9 \\
86.3\end{array}$ & $\begin{array}{l}0.0005-2 \\
2-15\end{array}$ & 0.43 & +0.45 & 2016 [183] \\
\hline $\begin{array}{l}\text { Porous Pd NTs/GCE } \\
\qquad[0.1 \mathrm{M} \mathrm{NaOH}]\end{array}$ & 6.58 & $0.005-10$ & 1 & +0.45 & 2015 [184] \\
\hline $\begin{array}{l}\text { Pd NPs-IFMC/GCE } \\
{[0.15 \mathrm{M} \mathrm{NaOH}]}\end{array}$ & - & $1-55$ & 200 & +0.40 & 2015 [185] \\
\hline $\begin{array}{l}\text { Pd nanocubes/GCE } \\
{[0.1 \mathrm{M} \mathrm{NaOH}]}\end{array}$ & 34 & $1-10$ & - & -0.05 & $2015[34]$ \\
\hline $\begin{array}{c}\text { Pd NPs-MWCNTs/GCE } \\
{[0.1 \mathrm{M} \mathrm{NaOH}]}\end{array}$ & 1275 & $1-22$ & 0.2 & -0.4 & 2014 [186] \\
\hline $\begin{array}{c}\text { Pd NPs-MWCNTs/GCE } \\
{[1 \mathrm{M} \mathrm{NaOH}]}\end{array}$ & 11 & $1-10$ & - & +0.025 & 2013 [187] \\
\hline \multicolumn{6}{|c|}{ (c) Mono-metallic Pt electrodes } \\
\hline $\begin{array}{l}\text { GFs Pt/GCE } \\
{[0.1 \mathrm{M} \mathrm{NaOH}]}\end{array}$ & $\begin{array}{l}46,060.9 \\
205.2\end{array}$ & $\begin{array}{l}0.0001-0.01 \\
0.01-20\end{array}$ & 0.03 & -0.15 & 2019 [164] \\
\hline $\begin{array}{l}\mathrm{Pt} \text { CNs } / \mathrm{FTO} \\
{[0.1 \mathrm{M} \mathrm{NaOH}]}\end{array}$ & 20.75 & $0.33-12.5$ & 0.7 & +0.2 & 2018 [188] \\
\hline $\begin{array}{c}\text { Pt particles-PANI/PtE } \\
{[0.1 \mathrm{M} \mathrm{NaOH}]}\end{array}$ & 215.8 & $0.1-12$ & 10 & +0.02 & 2018 [189] \\
\hline $\begin{array}{c}\text { Nanoporous } \mathrm{Pt} / \mathrm{PtE} \\
{\left[0.5 \mathrm{M} \mathrm{H}_{2} \mathrm{SO}_{4}\right]}\end{array}$ & 5.67 & $1-10$ & 800 & +0.4 & 2017 [190] \\
\hline $\begin{array}{l}\text { Pt NPs-GOH/GCE } \\
{[0.1 \mathrm{M} \mathrm{NaOH}]}\end{array}$ & 137.4 & $5-20$ & - & +0.1 & 2015 [131] \\
\hline $\begin{array}{l}\text { Pt nanoclusters-graphene/GCE } \\
\text { [0.1 M PBS] }\end{array}$ & 1.21 & $1-25$ & 30 & +0.05 & 2015 [111] \\
\hline $\begin{array}{c}\mathrm{Pt} \text { NFs-GO/GCE } \\
{[0.05 \mathrm{M} \text { PBS] }}\end{array}$ & $\begin{array}{l}1.26 \\
0.64\end{array}$ & $\begin{array}{c}0.002-10.3 \\
10.3-20.3\end{array}$ & 2 & +0.52 & 2013 [112] \\
\hline $\begin{array}{c}\text { Pt-PGA/GCE } \\
{[0.2 \mathrm{M} \text { PBS }]}\end{array}$ & 0.88 & $0.05-5.95$ & 11 & +0.35 & 2013 [191] \\
\hline
\end{tabular}


Table 2. Cont

\begin{tabular}{|c|c|c|c|c|c|}
\hline $\begin{array}{c}\text { Electrode } \\
\text { [Electrolyte] }\end{array}$ & $\begin{array}{c}\text { Sensitivity } \\
\left(\mu \mathrm{A} \mathrm{mM}^{-1} \mathrm{~cm}^{-2}\right)\end{array}$ & $\begin{array}{c}\text { Linear } \\
\text { Range }(\mathrm{mM})\end{array}$ & LOD $(\mu \mathrm{M})$ & $\begin{array}{c}\text { Working } \\
\text { Potential (V) * }\end{array}$ & $\begin{array}{c}\text { Year } \\
\text { [Reference] }\end{array}$ \\
\hline \multicolumn{6}{|c|}{ (c) Mono-metallic Pt electrodes } \\
\hline $\begin{array}{l}\text { Pt-MWCNTs/GCE } \\
{[0.1 \mathrm{M} \mathrm{NaOH}]}\end{array}$ & 106 & Up to 2.4 & - & -0.25 & 2013 [192] \\
\hline $\begin{array}{c}\text { Pt NFs-MWCNT / AuE } \\
{[0.2 \text { M PBS] }}\end{array}$ & 1.87 & $1-16$ & 48 & - & 2012 [193] \\
\hline \multicolumn{6}{|c|}{$\begin{array}{l}\text { * All potentials are with respect to the Ag/AgCl reference electrode. Abbreviation: AuE: Au electrode; CNTs: Carbon nanotubes; CSP: } \\
\text { Cynomorium songaricum polysaccharides; FTO: Fluorine-doped tin oxide; GCE: Glassy carbon electrode; GCNTs: Graphene-carbon } \\
\text { nanotube; GF: Graphene framework; GN: Graphene nanoplates; GO: Graphene oxide; GOH: Graphene oxide hydrogel; LOD: limit of } \\
\text { detection; MPA: Micropillar array; MWCNTs: Multiwalled carbon nanotubes; NCs: Nanocubes; NFs: Nano flowers; NPs: Nanoparticles; } \\
\text { NTs: Nanotubes; PAA: Poly(acrylic acid); PANI: Polyaniline; PBS: Phosphate-buffered saline; PBTh: Polybithiophene; PtE: Pt electrode; } \\
\text { SPCE: Screen-printed carbon electrode. }\end{array}$} \\
\hline $\begin{array}{c}\text { Electrode } \\
\text { [Electrolyte] }\end{array}$ & $\begin{array}{c}\text { Sensitivity } \\
\left(\mu \mathrm{A} \mathrm{mM}^{-1} \mathrm{~cm}^{-2}\right)\end{array}$ & $\begin{array}{c}\text { Linear } \\
\text { Range (mM) }\end{array}$ & $\begin{array}{l}\text { LOD } \\
(\mu \mathrm{M})\end{array}$ & $\begin{array}{c}\text { Working } \\
\text { Potential (V) * }\end{array}$ & $\begin{array}{c}\text { Year } \\
\text { [Reference] }\end{array}$ \\
\hline \multicolumn{6}{|c|}{ (a) Mono-metallic Co electrodes } \\
\hline $\begin{array}{l}\text { Co-MOF/GCE } \\
{[0.1 \mathrm{M} \mathrm{NaOH}]}\end{array}$ & 2860 & $1.0-1300.0$ & 0.19 & - & 2021 [194] \\
\hline $\begin{array}{l}\text { Co-PO-MA/NF } \\
{[0.1 \mathrm{M} \mathrm{NaOH}]}\end{array}$ & 3550 & $0.001-1.16$ & 1 & +0.55 & 2020 [195] \\
\hline $\begin{array}{c}\text { CoPc-graphene-IL/SPCE } \\
{[0.1 \mathrm{M} \mathrm{NaOH}]}\end{array}$ & - & $0.01-1.3$ & 0.67 & - & 2018 [196] \\
\hline $\begin{array}{l}\mathrm{Co}_{3} \mathrm{~N} \mathrm{NA} / \mathrm{TM} \\
{[0.1 \mathrm{M} \mathrm{NaOH}]}\end{array}$ & 3325.6 & $0.0001-2.5$ & 0.05 & +0.54 & 2018 [197] \\
\hline $\begin{array}{c}\text { Co-phosphate nanostructures/GCE } \\
{[0.1 \mathrm{M} \text { PBS] }}\end{array}$ & 7900 & $1-30$ & $3 \times 10^{-4}$ & +0.65 & 2018 [166] \\
\hline $\begin{array}{c}\mathrm{Co}_{4} \mathrm{~N}-\mathrm{NSs} / \mathrm{GCE} \\
{[0.1 \mathrm{M} \mathrm{NaOH}]}\end{array}$ & 1137.2 & $0.6-10$ & 0.1 & +0.55 & 2018 [198] \\
\hline $\begin{array}{c}\text { Co-phosphide NA/TM } \\
{[0.1 \mathrm{M} \mathrm{NaOH}]}\end{array}$ & 5168.6 & $5 \times 10^{-4}-1.5$ & 0.1 & +0.54 & 2017 [199] \\
\hline $\begin{array}{c}\text { Co-MWCNTs nanocomposite/MSPs } \\
{[0.1 \mathrm{M} \mathrm{NaOH}]}\end{array}$ & 727.4 & $\begin{array}{c}0.005-0.1 \\
0.2-3.6\end{array}$ & $\begin{array}{c}0.009 \\
0.3\end{array}$ & +0.43 & 2015 [200] \\
\hline $\begin{array}{l}\text { Co NPs / graphene } \\
{[0.1 \mathrm{M} \mathrm{NaOH}]}\end{array}$ & 4700 & $0.00167-0.47$ & 0.05 & +0.54 & 2015 [201] \\
\hline $\begin{array}{l}\text { Co NPs/ITO } \\
{[1 \mathrm{M} \mathrm{NaOH}]}\end{array}$ & 1720 & $0.005-0.18$ & 0.25 & +0.59 & 2014 [110] \\
\hline
\end{tabular}


Table 3. Cont.

\begin{tabular}{|c|c|c|c|c|c|}
\hline $\begin{array}{l}\text { Electrode } \\
\text { [Electrolyte] }\end{array}$ & 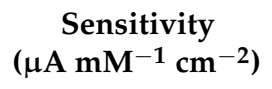 & $\begin{array}{c}\text { Linear } \\
\text { Range }(\mathrm{mM})\end{array}$ & $\begin{array}{l}\text { LOD } \\
(\mu \mathrm{M})\end{array}$ & $\begin{array}{c}\text { Working } \\
\text { Potential (V) * }\end{array}$ & $\begin{array}{c}\text { Year } \\
\text { [Reference] }\end{array}$ \\
\hline \multicolumn{6}{|c|}{ (b) Mono-metallic Cu electrodes } \\
\hline $\begin{array}{c}\text { Cu NPs-LIG/PIFs } \\
{[0.1 \mathrm{M} \mathrm{NaOH}]}\end{array}$ & 495 & $0.001-6$ & 0.39 & +0.50 & 2020 [125] \\
\hline $\begin{array}{l}\mathrm{Cu}-\mathrm{MOF} / \mathrm{GCE} \\
{[0.01 \mathrm{M} \mathrm{NaOH}]}\end{array}$ & 89 & $0.01-3.5$ & 0.0105 & +0.55 & 2018 [167] \\
\hline $\begin{array}{c}\mathrm{Cu} \text { NPs-N-graphene/GCE } \\
{[0.1 \mathrm{M} \mathrm{NaOH}]}\end{array}$ & 4846.9 & $1 \times 10^{-5}-0.1$ & 0.01 & +0.60 & $2017[128]$ \\
\hline $\begin{array}{c}\mathrm{Cu} \text { framework/Sandpaper } \\
{[0.1 \mathrm{M} \mathrm{NaOH}]}\end{array}$ & 2165.5 & $0.001-4.6$ & 0.03 & +0.45 & 2017 [202] \\
\hline $\begin{array}{l}\mathrm{Cu} \text { NWs } / \mathrm{rGO} \\
{[0.1 \mathrm{M} \mathrm{NaOH}]}\end{array}$ & 1625 & Up to 11 & 0.2 & +0.58 & 2016 [203] \\
\hline $\begin{array}{l}\mathrm{Cu}-\mathrm{PSi} / \mathrm{CPE} \\
{[0.1 \mathrm{M} \mathrm{NaOH}]}\end{array}$ & - & $\begin{array}{c}0.001-0.19 \\
0.19-2.3\end{array}$ & 0.2 & +0.55 & 2014 [143] \\
\hline $\begin{array}{c}\text { Cu-N-graphene/GCE } \\
{[0.1 \mathrm{M} \mathrm{NaOH}]}\end{array}$ & 48.1 & $0.004-4.5$ & 1.3 & +0.55 & 2014 [204] \\
\hline $\begin{array}{c}\mathrm{Cu} \text { NWs-MWCNTs/GCE } \\
{[0.1 \mathrm{M} \mathrm{NaOH}]}\end{array}$ & 1995 & Up to 3 & 0.26 & +0.55 & $2013[205]$ \\
\hline $\begin{array}{c}\text { Cu NWs-Nafion/GCE } \\
{[0.05 \mathrm{M} \mathrm{NaOH}]}\end{array}$ & 420.3 & Up to 3 & 0.035 & +0.60 & 2012 [139] \\
\hline $\begin{array}{c}\text { Cu NPs-graphene/GCE } \\
{[0.1 \mathrm{M} \mathrm{NaOH}]}\end{array}$ & 607 & $0.005-1.4$ & 0.2 & +0.55 & 2012 [206] \\
\hline \multicolumn{6}{|c|}{ (c) Mono-metallic Ni electrodes } \\
\hline $\begin{array}{l}\mathrm{Ni}-\mathrm{C} / \mathrm{SPCE} \\
{[0.1 \mathrm{M} \mathrm{KOH}]}\end{array}$ & 670 & $0.02-0.5$ & 8 & - & 2018 [127] \\
\hline $\begin{array}{l}\text { Ni plasma-modified graphene/GCE } \\
{[0.1 \mathrm{M} \mathrm{NaOH}]}\end{array}$ & 2213 & $0.1-3$ & 1 & +0.60 & 2017 [207] \\
\hline $\begin{array}{c}\mathrm{Ni}_{3} \mathrm{~S}_{2} / \mathrm{NF} \\
{[0.5 \mathrm{M} \mathrm{NaOH}]}\end{array}$ & 16,460 & $5 \times 10^{-4}-3$ & 0.82 & +0.55 & $2016[208]$ \\
\hline $\begin{array}{c}\mathrm{NiS} / \mathrm{ITO} \\
{[0.1 \mathrm{M} \mathrm{NaOH}]}\end{array}$ & 7430 & $0.005-0.045$ & 0.32 & +0.50 & 2015 [209] \\
\hline $\begin{array}{l}\mathrm{CNT}-\mathrm{Ni} / \mathrm{SiO}_{2} \\
{[0.1 \mathrm{M} \mathrm{NaOH}]}\end{array}$ & 813 & $0.001-0.11$ & 1 & +0.50 & $2015[210]$ \\
\hline $\begin{array}{c}3 \mathrm{D} \mathrm{Ni}_{3} \mathrm{~S}_{2} \mathrm{NSs} \text { arrays/NF } \\
{[0.5 \mathrm{M} \mathrm{NaOH}]}\end{array}$ & 6148 & $0.005-3$ & 1.2 & +0.49 & 2014 [211] \\
\hline $\begin{array}{c}\mathrm{Ni}_{3} \mathrm{~S}_{2} / \mathrm{MWCNTs} \\
{[0.1 \mathrm{M} \mathrm{NaOH}]}\end{array}$ & 3345 & $0.03-0.5$ & 1 & +0.54 & 2014 [212] \\
\hline $\begin{array}{c}\text { 3D porous Ni-SPCE/ITO } \\
{[0.1 \mathrm{M} \mathrm{NaOH}]}\end{array}$ & 2900 & $5 \times 10^{-4}-4$ & 0.07 & +0.50 & 2013 [213] \\
\hline $\begin{array}{l}\text { Ni-MWCNTs/GCE } \\
{[0.1 \mathrm{M} \mathrm{NaOH}]}\end{array}$ & 67.2 & $0.0032-17.5$ & 0.89 & +0.60 & 2012 [132] \\
\hline $\begin{array}{c}\text { Ni NPs-MWCNTs/GCE } \\
{[0.1 \mathrm{M} \mathrm{NaOH}]}\end{array}$ & 1438 & $0.001-1$ & 0.5 & +0.45 & $2011[214]$ \\
\hline
\end{tabular}

* All potentials are with respect to the $\mathrm{Ag} / \mathrm{AgCl}$ reference electrode. Abbreviation: CNT: Carbon nanotube; CPE: Carbon paste electrode; GCE: Glassy carbon electrode; IL: Ionic liquid; ITO: Indium tin oxide; LIG: Laser-induced graphene; MA: Micro-sheet arrays; MOF: Metal-organic framework; MSPs: Mild steel plates; MWCNTs: Multiwalled carbon nanotubes; NA: Nanowire array; NF: Ni foam; NPs: Nanoparticles; NSs: Nanosheets; NWs: Nanowires; PBS: Phosphate-buffered saline; Pc: Phthalocyanine; PIFs: Polyimide films; PO: Phosphate; PSi: Porous silicon; rGO: Reduced graphene oxide; SPCE: Screen-printed carbon electrode; TM: Titanium mesh. 


\section{Electroactive Materials of Bi-Metallic Materials (Alloys)}

As mentioned in the previous sections, to date, the mono-metallic electrocatalysts for the electro-oxidation of glucose have been widely investigated due to their relatively simple fabrication method, time-effective procedures, and proper electrocatalytic activity for the detection of glucose by the electrochemical technique. However, there still remains some dilemma in the mono-metallic electrocatalysts for the electro-oxidation of glucose. For example, Pt performs high electrocatalytic activity to the electro-oxidation of glucose. Nevertheless, the surface of the Pt active sites would be poisoned by the intermediates, which are generated from the electro-oxidation of glucose molecules $[105,215,216]$. Transition metal-based materials, such as $\mathrm{Co}, \mathrm{Cu}$, and $\mathrm{Ni}$, demonstrate high sensitivity. However, a high detection potential is necessary for triggering the electro-oxidation of glucose $[132,207,208]$.

Given that there remain some difficulties in the mono-metallic electrocatalysts, the bimetallic electrocatalysts have also been studied to solve the aforementioned dilemma [217-228]. Various combinations of the metals are present, such as Ag-Cu [217], Ag-Pd [218], AgPt [219], Au-Pt [220], Co-Pt [221], Cu-Ni [222,223], Ni-Fe [224], Ni-Pt [225,226], Pd-Pt [227], and $\mathrm{Pt}-\mathrm{Ru}$ [228]. According to the references, the integrations of different metals could be noble-noble, noble-transition, and transition-transition for tailoring each other. An example is shown in Section 7.1 to reveal the enhancements of the electrocatalytic activity by taking the advantage of the bi-metallic material. It is necessary to mention that the term "bi-metallic" indicates the materials, which are composed of more than one metal regardless of the structures of the materials. For example, the often-seen core-shell structure is also classified as a bi-metallic electroactive material in this review article.

\subsection{Bi-Metallic Pt-Au Alloy Nanomaterials}

Bi-metallic Pt-Au nanomaterials have been studied by Lin et al. [229] to overcome the difficulties in the mono-metallic materials. Again, Pt has been widely practiced in the non-enzymatic glucose sensor. However, it is well-known that Pt-based electrodes suffer from the drawbacks of poisoning effect because of the adsorption of the chloride ions from the human body fluid or blood and also the chemisorption of the intermediates from the products of electro-oxidation of glucose [230]. These chemical species are unavoidable in the reactions of the electro-oxidation of glucose. On the other hand, it is also known that the non-enzymatic glucose sensors possess relatively low selectivity than that of the enzymatic glucose sensors due to the possible interferences caused by simultaneous oxidation of various substances [231]. Integration of the Pt element with other materials could be a facile method to overcome the poisoning drawback of the Pt catalyst to promote the overall electrocatalytic activity, and also to enhance the selectivity for the non-enzymatic glucose sensors.

As mentioned in Section 7, the combination variety of the materials could be wide [217-228]. Among them, the bi-metallic Pt-Au nanomaterials are one of the promising candidates due to the following reasons, firstly, the anti-poisoning effect is realized effectively by the combination of the Pt-Au binary system. Secondly, the electrocatalytic activity could also be enhanced by the integration of $\mathrm{Pt}$ and Au metals. Thirdly, the performance of the non-enzymatic glucose sensor could be simply tailored via the fine-tuning of the size [232], shape [233], chemical composition [234], and structure [235] of the binary materials. Besides the abovementioned advantages, the current response and the selectivity [220] were reported to be greatly enhanced due to the synergistic effect [236]. Lastly, since Pt and $\mathrm{Au}$ both possess highly electrical conductivity, relatively low applied potential is required compared to other materials [237]. Based on the aforementioned truths, the electrode composed of the bi-metallic $\mathrm{Pt}-\mathrm{Au}$ is considered as a potential material for the electro-oxidation of glucose by the electrochemical technique. 


\subsection{Mechanisms of Electro-oxidation of Glucose by Pt and Pt-Au Electrocatalysts}

The mechanisms of the electro-oxidation of glucose by different electrocatalysts are listed in Table 1. Lin et al. [229] also illustrated the reaction mechanisms, which are shown in Figure 9, and the descriptions for the overall electro-oxidation of glucose are elucidated and summarized in the following steps.

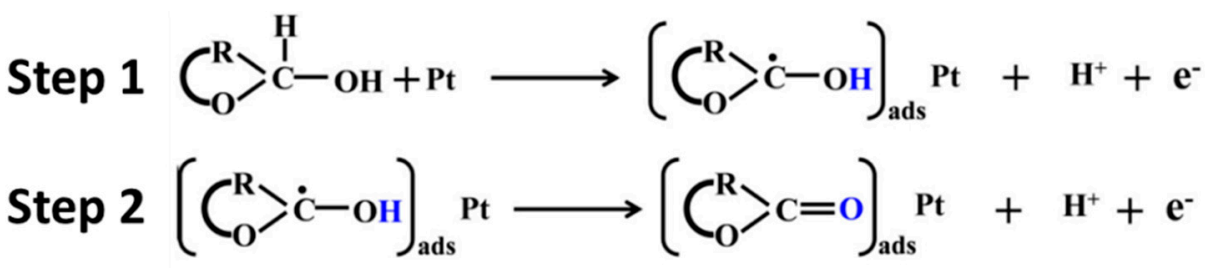

Step 3

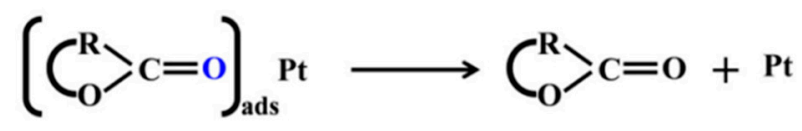

\section{Step 4}

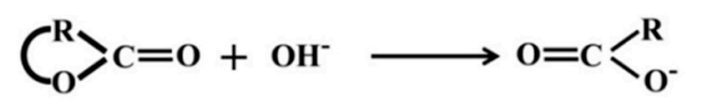

Figure 9. Illustrations for the mechanism of electro-oxidation of glucose by Pt electrode. (Atoms of $\mathrm{H}$ and $\mathrm{O}$ in blue are the adsorption sites) (Reproduced with permission from [229]. Copyright Elsevier, 2020).

Step 1: The chemisorption of the $\mathrm{C}-\mathrm{OH}$ functional group to the surface of the $\mathrm{Pt}$ electrocatalyst and the $\mathrm{C}-\mathrm{OH}$ functional group produces the $\mathrm{C}-\mathrm{OH}_{\mathrm{ads}}-\mathrm{Pt}$ showing a weak bonding between the $\mathrm{C}-\mathrm{OH}$ functional group and the $\mathrm{Pt}$ surface.

Step 2: The adsorbed C-OH functional group on the Pt electrode is oxidized on the $\mathrm{Pt}$ surface while the potential is raised. After electro-oxidation, glucose thus turns into the intermediate of gluconolactone and remains adsorbed on the Pt surface.

Step 3: The desorption of the adsorbed gluconolactone molecule takes place, and more or less, the surface of the Pt electrode is freed from the adsorption of the intermediate molecules.

Step 4: Gluconolactone, which is one of the products from the electro-oxidation of the glucose, could further react with $\mathrm{OH}^{-}$in the electrolyte and turn into its ionic state, such as the $\mathrm{C}_{-} \mathrm{OOR}^{-}$species.

There is a small difference between the mechanism described by Lin et al. [229] and Table 1. In Table 1, the active site of the $\mathrm{Pt}^{-} \mathrm{OH}_{\mathrm{ads}}$ is generated by the adsorption of the $\mathrm{OH}^{-}$ion in the electrolyte, while the $\mathrm{Pt}-\mathrm{OH}_{\mathrm{ads}}$ is generated by the adsorption of the $\mathrm{C}-\mathrm{OH}$ functional group in the glucose to the Pt surface. The critical step for the formation of the

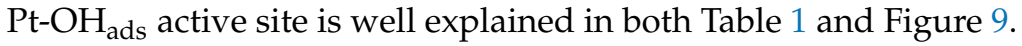

It is known that $\mathrm{Pt}$ is a promising material for the electro-oxidation of glucose due to its high electroactivity. However, some conventional problems still remain. There are a few reasons for the explanation of the inactivated Pt electrode. Firstly, since a certain potential should be applied to the working electrode, the formation of the Pt metallic oxide layer could bring the inactivation to the working electrode. Secondly, since the $\mathrm{C}=\mathrm{O}$ functional group shows high affinity to the Pt electrode, the Pt active sites are blocked by the intermediates and lose their electrocatalytic activity. The (1) passivation phenomenon caused by the formation of metal oxides on the electroactive sites at certain potential and the (2) poisoning effect from the aforementioned adsorption of the $\mathrm{C}=\mathrm{O}$ functional group on the electroactive sites resulted in the deteriorated performance of the electrocatalytic activity in the electro-oxidation of glucose. Therefore, a solution to the dilemma should be found.

In contrast with the Pt catalyst, although Au shows less electrocatalytic activity to the electro-oxidation of glucose than $\mathrm{Pt}$ [238], the anti-poisoning effect of Au is known to be outstanding $[61,239]$. With the introduction of Au into the Pt electrode as the secondary element, the surface energy could be effectively regulated and a remarkable anti-poisoning 
effect could be realized $[230,240]$. Hence, the overall electrocatalytic activity to the electrooxidation of glucose was promoted. In addition, due to the enhanced electrocatalytic activity of the electrode, the detection potential for glucose could be lowered and the undesired oxidation of the electrode thereby suppressed. The performances of the electrocatalytic activity and the resistance to the poisoning are greatly affected by the surface energy of the electrode, which could be further tuned by tailoring the chemical composition $[220,234]$, the atomic ratio between Pt and $\mathrm{Au}[234,241]$, and structure $[235,242]$. Based on the abovementioned premise, the performances of the electro-oxidation of glucose, such as the electrocatalytic activity, sensitivity, and detection potential, are foreseen to be promoted by the integration of Au into Pt electrode.

\subsection{Characterizations of the Bi-Metallic Pt-Au Electrocatalysts}

The microstructure images of the bi-metallic Pt-Au electrocatalysts are shown in Figure 10. The SEM micrograph of the PtAu (1:1)/C electrode is shown in Figure 10a and the TEM image is inserted into the upper-right corner. Judging from the SEM and TEM images, the spherical nanoparticles of the bi-metallic Pt-Au alloy, which were homogeneously dispersed, possessed an average diameter of $3-5 \mathrm{~nm}$. The $d$-spacing of the adjacent fringes for the cores of the spherical Pt-Au alloy NPs, which were $2.3 \AA$ and $2.0 \AA$, respectively, corresponded to the (111) and (200) planes of the face-centered cubic (fcc) PtAu (1:1) alloy (Figure 10b) [243-245].
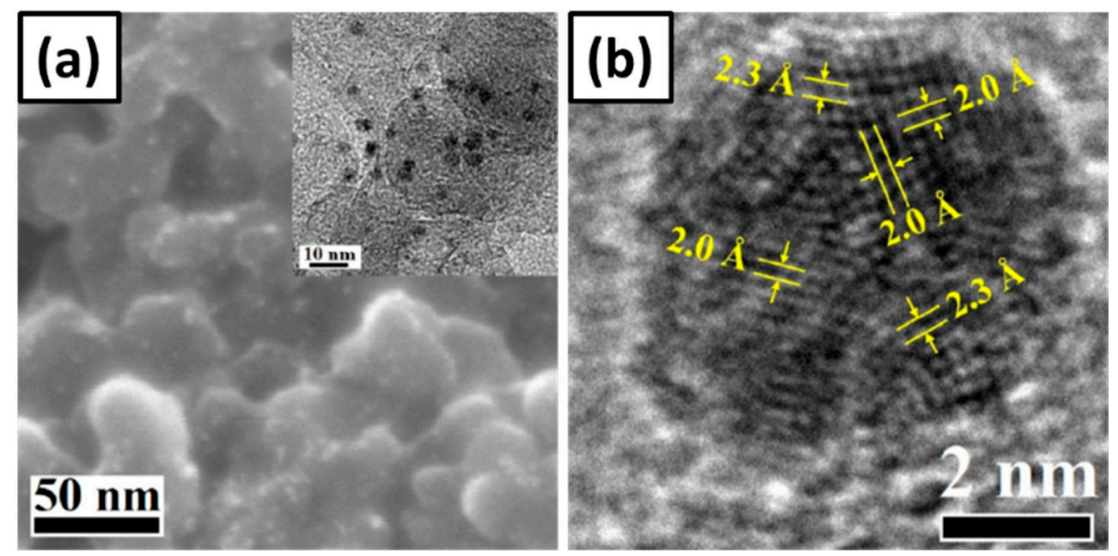

Figure 10. (a) SEM micrograph of the PtAu (1:1)/C modified electrode surface (Inserted figure at the upper-right corner: TEM image of the PtAu (1:1) alloy nanoparticle.) and (b) corresponding highresolution transmission electron microscopy (HRTEM). (Reproduced with permission from [229]. Copyright Elsevier, 2020).

The electro-oxidation of glucose analyzed by the LSV method on the (a) $\mathrm{Pt} / \mathrm{C}$, (b) $\mathrm{Au} / \mathrm{C}$, and (c) PtAu (1:1)/C electrodes are shown in Figure 11. In the Pt/C electrode (Figure 11a), two oxidation peaks, which indicated the electro-oxidation of glucose at $-0.13 \mathrm{~V}$ and $+0.12 \mathrm{~V}$, were observed as the glucose was introduced into the alkaline electrolyte (i.e., blue and red curves). In the case of the $\mathrm{Au} / \mathrm{C}$ electrode (Figure 11b), two similar oxidation peaks were also observed at approximately $-0.13 \mathrm{~V}$ and $+0.27 \mathrm{~V}$, possessing a relatively high current response. On the other hand, different from these two pure Pt and Au metallic electrodes, the PtAu (1:1)/C electrode exhibited a significantly enhanced current response to the electro-oxidation of glucose (Figure 11c). The well-defined two oxidation peaks were observed at relatively negative potentials of $-0.33 \mathrm{~V}$ and $+0.06 \mathrm{~V}$, respectively. The significant enhancement of the current response could be attributed to the promoted catalytic properties and the anti-poisoning effect of this bi-metallic $\mathrm{Pt}-\mathrm{Au}$ alloy electrode during the process of the electro-oxidation of glucose. 

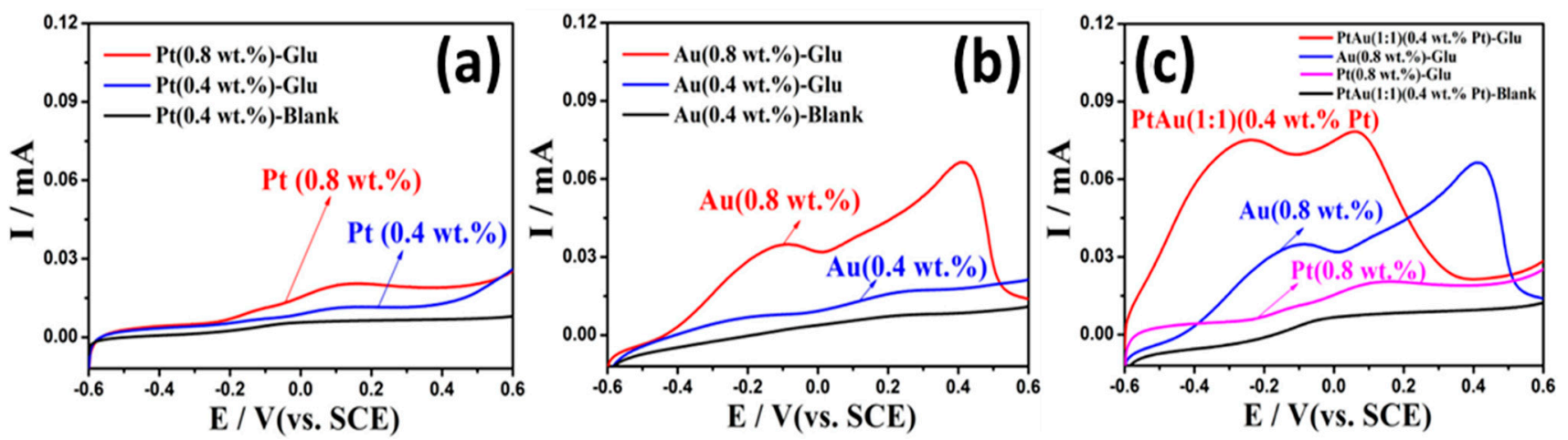

Figure 11. LSV measurements of the (a) $\mathrm{Pt} / \mathrm{C}$, (b) $\mathrm{Au} / \mathrm{C}$, and (c) $\mathrm{PtAu}(1: 1) / \mathrm{C}$ in $0.08 \mathrm{M} \mathrm{NaOH}$ with absence (black curve) and presence (blue, red, and pink curves) of $10 \mathrm{mM}$ glucose. (Reproduced with permission from [229]. Copyright Elsevier, 2015).

An illustration of the synergistic effect of metallic Pt and Au was shown in Figure 12. In the bi-metallic Pt-Au electrode, Pt plays a role in the dehydrogenation of glucose (step 1 in Figure 9), which leads to a strong electrocatalytic activity for the electro-oxidation of glucose. With the integration of $\mathrm{Au}$ to $\mathrm{Pt}$, Au shifted the $d$-band center of Pt outward to the Fermi level [246]. Therefore, the surface energy of Pt was reduced [247,248]. The lowered surface energy of $\mathrm{Pt}$ could weaken the adsorption strength between $\mathrm{Pt}$ and gluconolactone. Hence, the anti-poisoning effect was achieved.

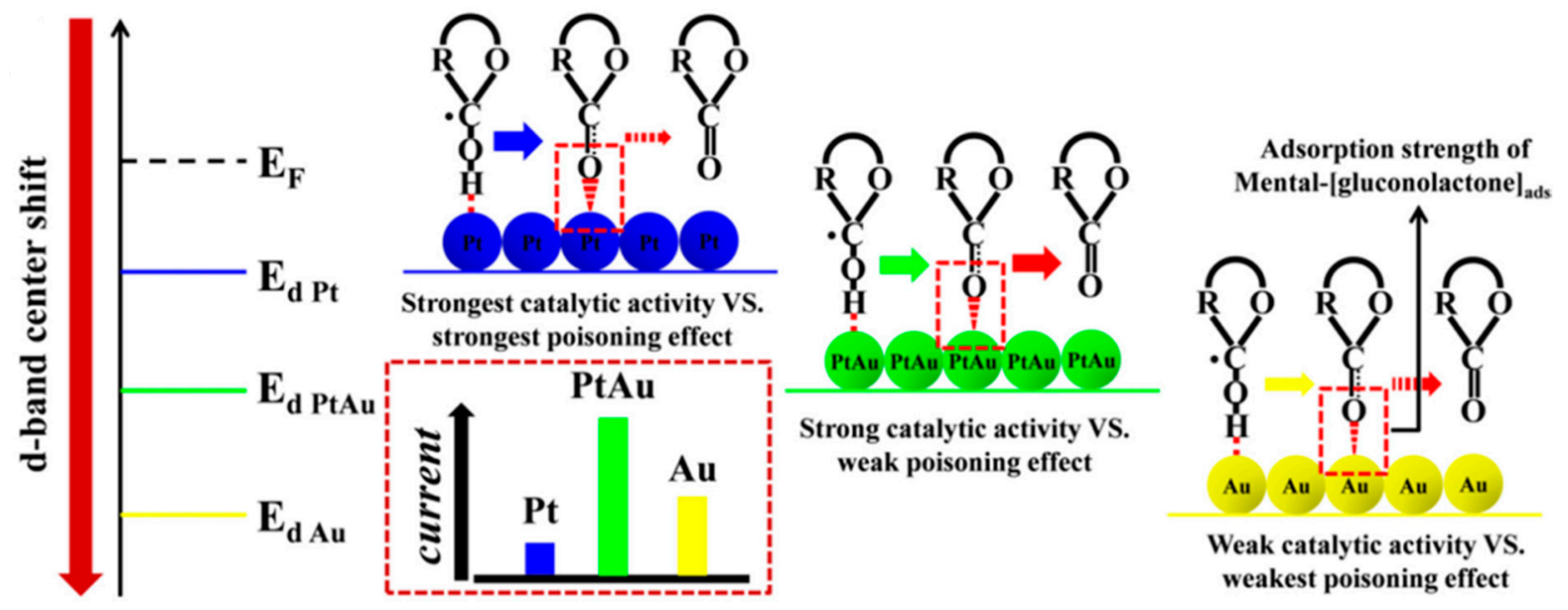

Figure 12. Schematic diagram of glucose electro-oxidation on the $\mathrm{Pt}, \mathrm{Pt}-\mathrm{Au}$, and $\mathrm{Au}$ catalysis surfaces as a function of the $d$-band center position. (Reproduced with permission from [229]. Copyright Elsevier, 2020).

The bi-metallic Pt-Au in different ratios of Pt:Au = 1:2, 1:1, 1:0.5, and 1:0.25 on the nano-carbon carrier were also examined (Figure 13a). The well-defined two oxidation peaks at approximately -0.10 and $+0.27 \mathrm{~V}$ were found in all LSV curves in Figure 13a. The current response increased with the augmentation of the Au ratio and the results agreed well with those examinations in Figure 11. The oxidation peak at around $+0.27 \mathrm{~V}$ shifted positively with the increment of the Au ratio due to the weaker electrocatalytic activity of $\mathrm{Au}$ than that of $\mathrm{Pt}$ to the electro-oxidation of glucose. These results also followed the analysis in Figure 11 well. On the other hand, the oxidation peak at approximately $-0.10 \mathrm{~V}$ increased as the $\mathrm{Au}$ amount increased, reached its maximum current response as the Pt:Au ratio was 1:1, and decreased again with further augmentation of the Au concentration. The maximum current response of this oxidation peak at $-0.10 \mathrm{~V}$ of the PtAu (1:1) electrode was due to the balance between the Pt and Au. Therefore, the PtAu (1:1)/C electrode was considered to be the optimized one. 

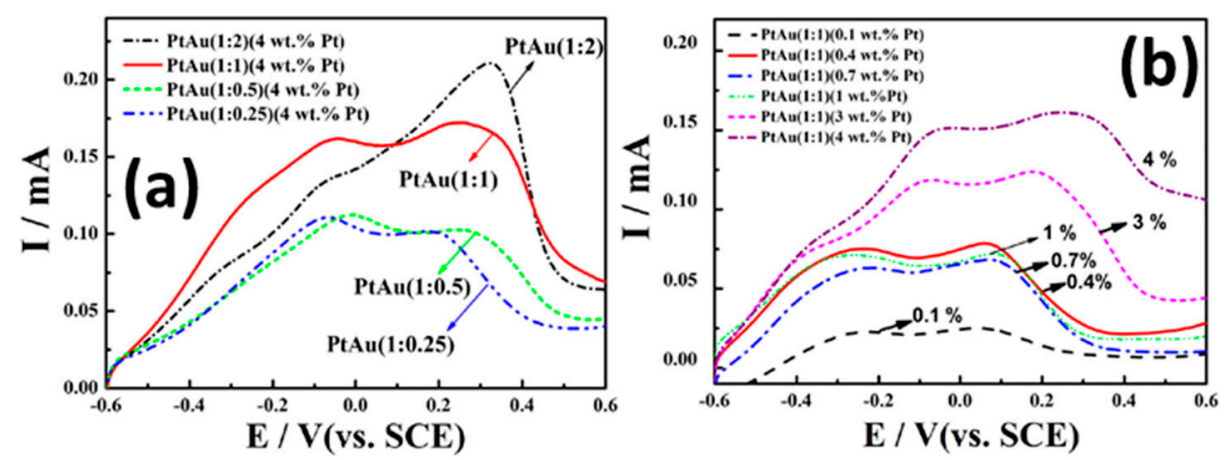

Figure 13. (a) LSV measurements for the PtAu (1:x)/C electrodes with different $\mathrm{Pt}: \mathrm{Au}$ ratios (i.e., $x=2$, $1,0.5$, and 0.25 ) recorded in the $0.08 \mathrm{M} \mathrm{NaOH}$ containing $10 \mathrm{mM}$ glucose. (b) LSV measurements for the PtAu (1:1)/C with different metal loading in $0.08 \mathrm{M} \mathrm{NaOH}$ containing $10 \mathrm{mM}$ glucose. (Reproduced with permission from [229]. Copyright Elsevier, 2020).

Different loading amounts of metals at the ratio of $\mathrm{Pt}: \mathrm{Au}=1: 1$ were also examined for further optimization of the electrocatalytic activity of the electrode by similar LSV measurements (Figure 13b). The loading amounts of $0.1,0.4,0.7,1,3$, and $4 \mathrm{wt} . \% \mathrm{Pt}$ were conducted.

\subsection{Comparison of the Mono-Metallic and the Bi-Metallic Electrodes}

The comparison amongst the bi-metallic materials is shown in Table 4. It was found that, with the integration of the noble metals, the average detection potential of the (b) nobletransition bi-metallic electrodes at $+0.38 \mathrm{~V}$ was lower than that of the (c) transition-transition bi-metallic electrodes at $+0.48 \mathrm{~V}$, while the (a) noble-noble bi-metallic electrodes demonstrate the lowest average detection potential at $+0.04 \mathrm{~V}$. The average sensitivity of the (c) transition-transition bi-metallic electrodes was also enhanced compared to those in Table 3. The LOD was greatly enhanced by integrating the mono-noble metals (Table 2) into the (a) noble-noble bi-metallic electrodes (Table 4a). To conclude, the performances of the electrodes were generally enhanced by the integration of mono-metallic materials (Tables 2 and 3) into the bi-metallic materials (Table 4). On the other hand, since the mechanisms for the electro-oxidation of glucose are similar to those in the mono-metallic ones (Tables 2 and 3), they are not explained in this section.

Table 4. The electrodes for the sensing of glucose by the (a) noble-noble, (b) noble-transition, and (c) transition-transition bi-metallic materials within this decade. The performances are compared in terms of sensitivity, linear range, limit of detection (LOD), and working potential. The working potentials are based on the reference electrode of $\mathrm{Ag} / \mathrm{AgCl}$.

\begin{tabular}{|c|c|c|c|c|c|}
\hline $\begin{array}{c}\text { Electrode } \\
\text { [Electrolyte] }\end{array}$ & $\begin{array}{c}\text { Sensitivity } \\
\left(\mu \mathrm{A} \mathrm{mM}^{-1} \mathrm{~cm}^{-2}\right)\end{array}$ & Linear Range (mM) & $\begin{array}{l}\text { LOD } \\
(\mu \mathrm{M})\end{array}$ & $\begin{array}{c}\text { Working } \\
\text { Potential (V) * }\end{array}$ & $\begin{array}{c}\text { Year } \\
\text { [Reference] }\end{array}$ \\
\hline \multicolumn{6}{|c|}{ (a) Noble-noble bi-metallic electrodes } \\
\hline $\begin{array}{l}\text { Pt-Au-Carbon/GCE } \\
{[0.08 \mathrm{M} \mathrm{NaOH}]}\end{array}$ & - & $0.01-10$ & 3 & -0.28 & 2020 [229] \\
\hline $\begin{array}{l}\text { Pd@Pt CINPs } \\
{[0.1 \mathrm{M} \mathrm{PB}]}\end{array}$ & 15.14 & $1-8.5$ & 1.92 & -0.10 & 2019 [249] \\
\hline $\begin{array}{l}\text { Honeycomb-like Au-Pt films/Si } \\
{[0.5 \mathrm{M} \mathrm{KOH}]}\end{array}$ & 109.3 & $0.02-10$ & 12.9 & -0.01 & 2016 [250] \\
\hline $\begin{array}{c}\text { Ag-Pt hollow NPs/rGO } \\
{[0.2 \mathrm{M} \text { PBS }]}\end{array}$ & 129.3 & $0.003-7.72$ & 1.8 & +0.30 & 2016 [251] \\
\hline $\begin{array}{c}\text { Pd-Pt NCbs-rGO/GCE } \\
{[0.1 \mathrm{M} \mathrm{NaOH}]}\end{array}$ & 170 & $0.3-6.8$ & 41.1 & -0.05 & 2016 [252] \\
\hline $\begin{array}{c}\text { Hollow Ag-Pt NPs/Carbon } \\
{[0.2 \mathrm{M} \text { PBS] }}\end{array}$ & 7 & $1-12$ & 13 & +0.30 & $2015[219]$ \\
\hline
\end{tabular}


Table 4. Cont.

\begin{tabular}{|c|c|c|c|c|c|}
\hline $\begin{array}{c}\text { Electrode } \\
\text { [Electrolyte] }\end{array}$ & 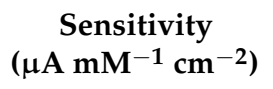 & Linear Range (mM) & $\begin{array}{l}\text { LOD } \\
(\mu \mathrm{M})\end{array}$ & $\begin{array}{c}\text { Working } \\
\text { Potential (V) * }\end{array}$ & $\begin{array}{c}\text { Year } \\
\text { [Reference] }\end{array}$ \\
\hline $\begin{array}{c}\text { Mesoporous Au-Pt NDs/GCE } \\
{[0.1 \mathrm{M} \mathrm{NaOH}]}\end{array}$ & - & $1 \times 10^{-5}-0.1$ & 0.001 & -0.35 & 2015 [253] \\
\hline $\begin{array}{c}\mathrm{Pt}_{3} \mathrm{Pd} \text { NPs-rGO/GCE } \\
{\left[0.5 \mathrm{M} \mathrm{H}_{2} \mathrm{SO}_{4}\right]}\end{array}$ & 1.52 & $0.03-3$ & 0.002 & +0.11 & 2015 [254] \\
\hline $\begin{array}{c}\text { Pt-Pd NCbs-GNSs/GCE } \\
{[0.05 \text { M PBS] }}\end{array}$ & 1.4 & $0.5-24.5$ & - & +0.30 & 2014 [227] \\
\hline $\begin{array}{c}\text { Pt-Pd NTAs / Au electrode } \\
{[0.1 \text { M PBS] }}\end{array}$ & 41.5 & Up to 10 & - & +0.20 & 2014 [255] \\
\hline \multicolumn{6}{|c|}{ (b) Noble-transition bi-metallic electrodes } \\
\hline $\begin{array}{l}\text { Cu-Ag NCs/GCE } \\
{[0.1 \mathrm{M} \mathrm{NaOH}]}\end{array}$ & 1340 & $0.01-30$ & 0.6 & +0.40 & 2020 [217] \\
\hline $\begin{array}{c}\text { Pd-Mn NPs-rGO/GCE } \\
{[0.1 \mathrm{M} \mathrm{NaOH}]}\end{array}$ & $\begin{array}{l}52.2 \\
22.6\end{array}$ & $\begin{array}{l}0.02-1.15 \\
1.15-4.88\end{array}$ & 1.25 & -0.05 & $2020[256]$ \\
\hline $\begin{array}{c}\text { Pt-Ni@AC/GCE } \\
{[0.1 \mathrm{M} \mathrm{NaOH}]}\end{array}$ & 40,900 & $0.025-12$ & 0.052 & - & 2020 [257] \\
\hline $\begin{array}{l}\text { Pd-Ni NPs-rGO/GCE } \\
{[0.1 \mathrm{M} \mathrm{NaOH}]}\end{array}$ & 37,500 & $0.05-1.1$ & 0.15 & - & 2019 [258] \\
\hline $\begin{array}{c}\mathrm{Ni@Pt-rGO/GCE} \\
{[0.1 \mathrm{M} \mathrm{NaOH}]}\end{array}$ & - & $0.008-10$ & 8 & +0.60 & 2018 [226] \\
\hline $\begin{array}{c}\text { Stone-like Pt-Ni NPs/GCE } \\
{[0.01 \mathrm{M} \mathrm{PB}]}\end{array}$ & 40.17 & $0.5-40$ & 0.35 & +0.48 & 2018 [259] \\
\hline $\begin{array}{c}\text { Au-Ni multilayer NWA/ITO } \\
{[0.2 \mathrm{M} \mathrm{NaOH}]}\end{array}$ & $\begin{array}{l}3372 \\
1906\end{array}$ & $\begin{array}{l}2.5 \times 10^{-4}-2 \\
2-5.5\end{array}$ & 0.1 & +0.60 & $2017[260]$ \\
\hline $\begin{array}{c}\mathrm{Cu}-\mathrm{Ag} / \mathrm{NF} \\
{[0.5 \mathrm{M} \mathrm{NaOH}]}\end{array}$ & 7745.7 & $0.005-3.5$ & 0.08 & +0.49 & 2015 [37] \\
\hline $\begin{array}{c}\text { Co@Pt core-shell NPs/GCE } \\
{[0.1 \mathrm{M} \mathrm{PB}]}\end{array}$ & 2.26 & $1-30$ & 300 & 0 & 2015 [261] \\
\hline $\begin{array}{l}\text { Pt-Ni NWs-PC/GCE } \\
{[0.1 \mathrm{M} \mathrm{NaOH}]}\end{array}$ & 920 & $0.002-2$ & 1.5 & +0.50 & 2011 [225] \\
\hline \multicolumn{6}{|c|}{ (c) Transition-transition bi-metallic electrodes } \\
\hline $\begin{array}{c}\text { Ni-Fe NPs-PANI/FTO } \\
{[0.1 \mathrm{M} \mathrm{NaOH}]}\end{array}$ & 1050 & $0.02-1$ & 0.5 & +0.55 & $2021[224]$ \\
\hline $\begin{array}{l}\mathrm{Ni@Cu-MOF/GCE} \\
{[0.1 \mathrm{M} \mathrm{NaOH}]}\end{array}$ & 1703.3 & $0.005-2.5$ & 1.67 & - & 2020 [262] \\
\hline $\begin{array}{l}\mathrm{Cu}-\mathrm{Ni} / \text { graphene sheets } \\
{[0.1 \mathrm{M} \mathrm{NaOH}]}\end{array}$ & $\begin{array}{c}314,285 \\
17,857 \\
1678\end{array}$ & $\begin{array}{c}5 \times 10^{-5}-2.4 \times 10^{-4} \\
2.4 \times 10^{-4}-0.00233 \\
0.00233-2.174\end{array}$ & 0.003 & +0.66 & 2019 [263] \\
\hline $\begin{array}{c}\text { Ni-Co-MOF-NSA/Au electrode } \\
{[0.1 \mathrm{M} \mathrm{NaOH}]}\end{array}$ & 684.4 & $0.001-8$ & 0.29 & +0.55 & 2019 [264] \\
\hline $\begin{array}{c}\text { Cu-Ni-NF/CNSA } \\
{[0.1 \mathrm{M} \mathrm{NaOH}]}\end{array}$ & 17,120 & $0.2-2.72$ & 0.067 & +0.54 & 2018 [126] \\
\hline $\begin{array}{c}\text { PANI@Cu-Ni NCs/GCE } \\
{[0.1 \mathrm{M} \mathrm{NaOH}]}\end{array}$ & 1030 & $0.1-5.6$ & 0.2 & +0.55 & 2018 [222] \\
\hline $\begin{array}{c}\text { Cu-Ni bi-metallic NCs/GCE } \\
{[0.1 \mathrm{M} \mathrm{NaOH}]}\end{array}$ & 63.87 & $0.01-18$ & 8 & +0.51 & 2017 [223] \\
\hline
\end{tabular}


Table 4. Cont.

\begin{tabular}{|c|c|c|c|c|c|}
\hline $\begin{array}{c}\text { Electrode } \\
\text { [Electrolyte] }\end{array}$ & 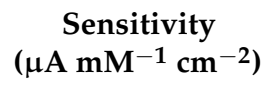 & Linear Range (mM) & $\begin{array}{l}\text { LOD } \\
(\mu \mathrm{M})\end{array}$ & $\begin{array}{c}\text { Working } \\
\text { Potential (V) * }\end{array}$ & $\begin{array}{c}\text { Year } \\
\text { [Reference] }\end{array}$ \\
\hline \multicolumn{6}{|c|}{ (c) Transition-transition bi-metallic electrodes } \\
\hline $\begin{array}{l}\text { Cu-Ni thin film/Cu substrate } \\
{[0.1 \mathrm{M} \mathrm{NaOH}]}\end{array}$ & 240.1 & $0-10$ & - & +0.50 & $2017[265]$ \\
\hline $\begin{array}{c}\text { Ni-Co NWs-MWCNTs/GCE } \\
{[0.1 \mathrm{M} \mathrm{NaOH}]}\end{array}$ & 695 & $0.005-10$ & 1.2 & +0.45 & 2016 [129] \\
\hline $\begin{array}{l}\text { Ni-Co-MSN/GCE } \\
{[0.1 \mathrm{M} \mathrm{NaOH}]}\end{array}$ & 536.6 & $0.001-5$ & 0.39 & +0.50 & 2015 [142] \\
\hline
\end{tabular}

* All potentials are with respect to the $\mathrm{Ag} / \mathrm{AgCl}$ reference electrode. Abbreviation: $\mathrm{AC}$ : Activated carbon; CINPs: Concave island nanoparticles; CNSA: Carbon nanosheet array; FTO: Fluorine tin oxide; GCE: Glassy carbon electrode; GNSs: Graphene nanosheets; ITO: Indium tin oxide; MOF: Metal-organic frameworks; MSN: Mesoporous silica nanoparticles; NCbs: Nanocubes; NCs:Nanocomposites; NDs: Nanodendrites; NF: Nickel foam; NPs: Nanoparticles; NSA: Nanosheets array; NTAs: Nanotube arrays; NWA: Nanowire array; NWs: Nanowires; PANI: Polyaniline; PB: Phosphate-buffer; PBS: Phosphate-buffered saline; PC: Polycarbonate; rGO: reduced graphene oxide.

\subsection{A Prospective Approach to the Bi-Metallic Electrodes}

Jonke et al. [266,267] and Schwartz et al. [268] have reported that the deposition of the bi-metallic Au-Pd on the polyaniline (PANI) supporting material could be controlled at the atomic level. In addition, the deposition sequence of the Au and Pd elements could also be manipulated by the flow cell system, which was controlled by the flow regulator and the potentiostat. It is further presented that the current response of the electro-oxidation of the 2-propanol $\left(\mathrm{C}_{3} \mathrm{H}_{7} \mathrm{OH}\right)$ altered with the different configurations of the atomic $\mathrm{Au}$ Pd clusters [266,267]. The discrimination between the alcohol series, such as methanol, ethanol, propanol, and butanol, has also been reported [269-272]. Although the articles were concerned with the electro-oxidation of the alcohol series in the alkaline solution, the reaction mechanisms are very similar to those of the electro-oxidation of glucose and the interfering molecules, such as ascorbic acid (AA), uric acid (UA), dopamine (DA), fructose, and so on. Therefore, it is considered that the atomic bi-metallic catalysts deposited supporting material of PANI could be a promising material for the electro-oxidation of glucose in the alkaline solution. In addition, according to the literature [266-272], the isomers of the propanol, such as 1-propanol and 2-propanol, could also be recognized by the atomic metal and/or alloy electrodes. It is thus deduced that the isomers of the glucose, such as the $\alpha$-D-glucose and the $\beta$-D-glucose are also expected to be recognized by the atomic metal and/or alloy electrodes.

According to the aforementioned results, it is highly possible to enhance the electrocatalytic activity, promote the anti-poisoning effect, and improve the selectivity of the electrode materials for the electro-oxidation of glucose by combining the atomic deposition of alloy systems via the flow cell system [266-272]. In addition, a great variety of the metals, similar to those in Table 4, is considered to be realized by simply altering the compounds of the metal salts in the electrolyte, such as $\mathrm{KAuCl}_{4}, \mathrm{~K}_{2} \mathrm{PdCl}_{4}, \mathrm{~K}_{2} \mathrm{PtCl}_{4}, \mathrm{~K}_{2} \mathrm{CoCl}_{4}$, and $\mathrm{KNiCl}_{4}$. Based on the abovementioned techniques, it cannot only reduce the usage of the metal salts but also increase the electroactive surface area by shrinking down the size of the electroactive catalysts.

A flow chart for the proposed research and the foreseen outcomes is shown in Figure 14. The flow cell (transparent, light gray, and disk-shaped container), which is connected to the flow rate controller and the potentiostat, is used for the deposition of the atomic clusters of the metals or alloys (Figure 14a). The metal salt, such as $\mathrm{KAuCl}_{4}$, $\mathrm{K}_{2} \mathrm{PdCl}_{4}, \mathrm{~K}_{2} \mathrm{PtCl}_{4}, \mathrm{~K}_{2} \mathrm{CoCl}_{4}$, and $\mathrm{KNiCl}_{4}$, flows in from the left-hand side inlet and the remaining unconsumed metal salt flows out from the right-hand side outlet (light gray tubes represent the inlet and outlet). The reference electrode (green bar) is inserted into the flow cell from the top. The Pt counter electrode (dark gray square sheet) is clamped into the flow cell. The glassy carbon electrode (GCE) is used as the working electrode (yellow stick in the front), which is inserted from the front side of the flow cell. Prior to the deposition 
of the atomic clusters of the metals or alloys, a thin PANI film (blue network structure) is electro-polymerized on the surface of GCE (Figure 14b). The aforementioned components describe the flow cell system.

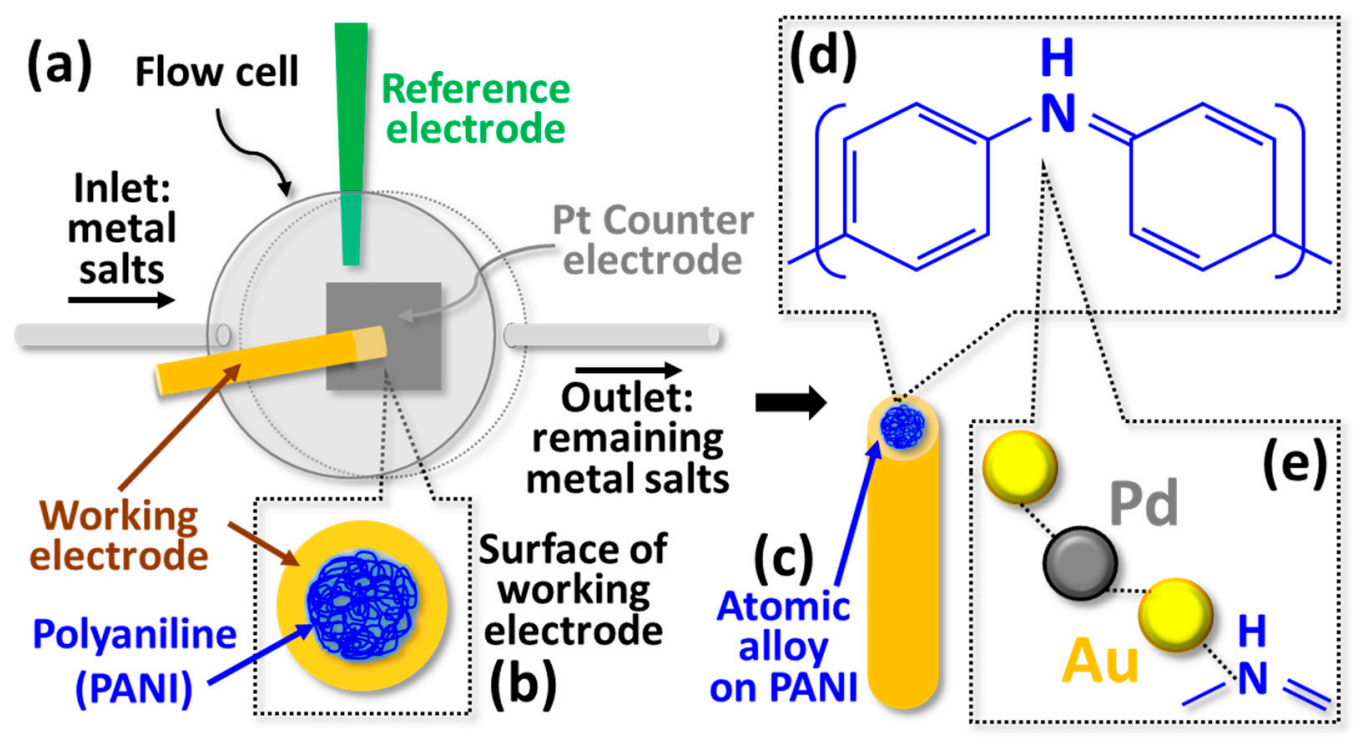

(h)

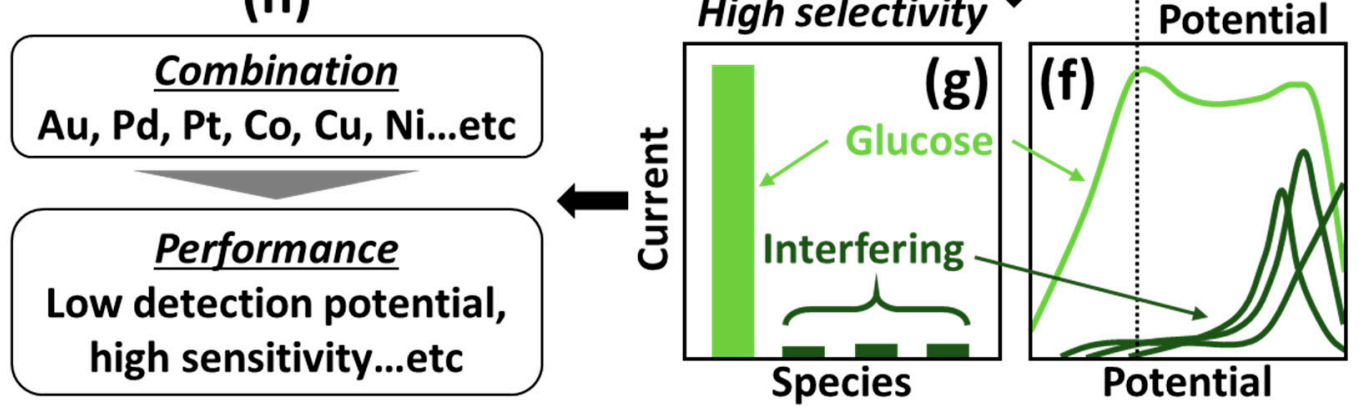

Figure 14. (a) The flow cell system, which is connected to the flow controller and the potentiostat, is for the atomic deposition of metal or alloy. (b) The glassy carbon electrode (GCE) (yellow color) is inserted into the front side of the flow cell and the PANI (network structure and blue color) is deposited on the surface of GCE prior to the atomic deposition of metal or alloy. (c) After the atomic deposition of metal or alloy on the PANI/GCE. (d) Illustration of the metal or alloy around the functional group of PANI. (e) Close-up image of the metal or alloy around the functional group of PANI. (Au (golden color) and Pd (gray color) are used as an example) (f) LSV curves of the electro-oxidation of glucose (light green color) and interfering molecules (dark green color), such as AA, DA, and UA. (g) Current responses from the glucose and the interfering molecules. (h) The choice of various elements and the possible outcomes from the different integration of chemical composition and different configurations of the atomic clusters.

After the electro-deposition of PANI on GCE, the atomic clusters of metals or alloys are deposited on the surface of PANI/GCE by the flow cell system ((Figure 14c). A close-up figure around the functional group of PANI is shown in Figure 14d. A further close-up figure at the functional group of PANI and the atomic cluster is shown in Figure 14e. The atomic clusters of metals or alloys are bonded to the functional group of PANI. Here, two atoms of $\mathrm{Au}$ (golden sphere) and Pd (gray sphere) were used as an example. Some expected LSV curves of the glucose (light green curve) and the interfering molecules (dark green curves), such as AA, DA, and UA, are shown in Figure 14f. The current responses from the glucose (light green bar) and the interfering molecules (dark green bars), which are read and quantified into numbers from the LSV curves of Figure 14f, are shown in Figure $14 \mathrm{~g}$. High selectivity could be expected from the combination of the atomic Au-Pd clusters. 
Finally, by integrating different elements, the promoted performances (i.e., low detection potential and high sensitivity) are foreseen to be realized (Figure 14h).

\section{Electroactive Materials of Oxide Compounds}

In Section 6, some of the transition metals are listed and elaborated. However, the longterm stability of transition metals is considered to be low while the transition metals are in their metallic states. This could be ascribed to the oxidation reaction of these transition metals. Therefore, the electrocatalysts, which are composed of transition metals, are usually coupled with carbon, nitrogen, sulfur, phosphorus, and so forth. For example, the electrocatalysts of the $\mathrm{Co}_{3} \mathrm{~N}$ [197], $\mathrm{Co}_{4} \mathrm{~N}$ [198], Co-P [166,199], Cu-N [128,204], Ni-C [127], $\mathrm{Ni}_{3} \mathrm{~S}_{2}[207,211,212]$, and NiS [209] are often investigated compounds. Hence, transition metals are usually utilized in their oxidized states such as $\mathrm{Co}_{3} \mathrm{O}_{4}, \mathrm{CuO}, \mathrm{NiO}$, and $\mathrm{Fe}_{2} \mathrm{O}_{3}$, for solving the long-term stability difficulty. According to the mechanisms in Table 1, it is also found that the metal-oxides are the necessary media for the electro-oxidation of glucose. The mechanisms for the electro-oxidation of glucose by the transition metals have been already discussed in Section 6.2. Therefore, the explanation was left out in this section. Some of the literature concerning transition metal oxides within this decade are listed and compared in Table 5.

Table 5. The electrodes for the sensing of glucose by the transition metal oxides of (a) Co, (b) $\mathrm{Cu}$, and (c) Ni materials within this decade. The performances are compared in terms of sensitivity, linear range, limit of detection (LOD), and working potential. The working potentials are based on the reference electrode of $\mathrm{Ag} / \mathrm{AgCl}$.

\begin{tabular}{|c|c|c|c|c|c|}
\hline $\begin{array}{c}\text { Electrode } \\
\text { [Electrolyte] }\end{array}$ & 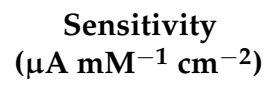 & $\begin{array}{l}\text { Linear Range } \\
\quad(\mathrm{mM})\end{array}$ & $\begin{array}{l}\text { LOD } \\
(\mu \mathrm{M})\end{array}$ & $\begin{array}{c}\text { Working } \\
\text { Potential (V) * }\end{array}$ & $\begin{array}{c}\text { Year } \\
\text { [Reference] }\end{array}$ \\
\hline \multicolumn{6}{|c|}{ (a) Electrodes containing Co oxides } \\
\hline $\begin{array}{c}\mathrm{Co}_{3} \mathrm{O}_{4} \mathrm{HAA} / \mathrm{GCE} \\
{[0.1 \mathrm{M} \mathrm{NaOH}]}\end{array}$ & 839.3 & $5.3 \times 10^{-4}-19$ & 0.53 & +0.60 & 2018 [273] \\
\hline $\begin{array}{c}\mathrm{Co}_{3} \mathrm{O}_{4}-\mathrm{rGO} / \mathrm{SPCE} \\
{[0.1 \mathrm{M} \mathrm{KOH}]}\end{array}$ & 1315 & $0.001-0.5$ & 0.4 & +0.35 & 2018 [274] \\
\hline $\begin{array}{c}\mathrm{Co}_{3} \mathrm{O}_{4} @ \text { graphene/GCE } \\
{[0.1 \mathrm{M} \mathrm{NaOH}]}\end{array}$ & 628 & $0.02-8$ & 0.04 & +0.55 & 2017 [275] \\
\hline $\begin{array}{c}\mathrm{Co}_{3} \mathrm{O}_{4} \text { porous film/GCE } \\
{[0.1 \mathrm{M} \mathrm{NaOH}]}\end{array}$ & 366 & Up to 3 & 1.0 & +0.60 & 2016 [276] \\
\hline $\begin{array}{c}\mathrm{Co}_{3} \mathrm{O}_{4}-\mathrm{HND} / \mathrm{GCE} \\
{[0.1 \mathrm{M} \mathrm{KOH}]}\end{array}$ & 708.4 & $2-6.06$ & 0.58 & +0.55 & 2016 [277] \\
\hline $\begin{array}{c}\mathrm{Co}_{3} \mathrm{O}_{4} \mathrm{NFs}-\mathrm{GOH} / \mathrm{GCE} \\
{[0.1 \mathrm{M} \mathrm{NaOH}]}\end{array}$ & 492.8 & $0.25-10$ & - & +0.62 & 2016 [278] \\
\hline $\begin{array}{c}\mathrm{Co}_{3} \mathrm{O}_{4} / \mathrm{GCE}-\mathrm{Nafion} \\
{[0.1 \mathrm{M} \mathrm{NaOH}]}\end{array}$ & 1618.7 & $0.1-50$ & 0.1 & +0.5 & 2015 [279] \\
\hline $\begin{array}{c}\mathrm{Co}_{3} \mathrm{O}_{4} \mathrm{OMC} / \mathrm{GCE} \\
{[0.1 \mathrm{M} \mathrm{NaOH}]}\end{array}$ & 955.9 & $0.9-7$ & 1.0 & +0.55 & 2015 [280] \\
\hline $\begin{array}{c}\mathrm{Co}_{3} \mathrm{O}_{4} \mathrm{NWs} / \mathrm{GCE} \\
{[0.1 \mathrm{M} \mathrm{NaOH}]}\end{array}$ & 45.8 & $0.001-12$ & 0.27 & +0.20 & 2015 [281] \\
\hline $\begin{array}{c}\mathrm{Co}_{3} \mathrm{O}_{4} \mathrm{NFs} / \mathrm{GCE} \\
{[0.5 \mathrm{M} \mathrm{NaOH}]}\end{array}$ & 1440 & $0.005-12$ & 0.08 & +0.47 & $2013[40]$ \\
\hline \multicolumn{6}{|c|}{ (b) Electrodes containing $\mathrm{Cu}$ oxides } \\
\hline $\begin{array}{l}\mathrm{CuO} \text { MTs/GCE } \\
{[0.05 \mathrm{M} \mathrm{NaOH}]}\end{array}$ & $\begin{array}{l}992.1 \\
541.8\end{array}$ & $\begin{array}{l}0.001-1.164 \\
1.164-5.664\end{array}$ & 0.31 & +0.70 & 2019 [282] \\
\hline $\begin{array}{c}\mathrm{CuO} \text { nanodisk/SPCE } \\
{[0.1 \mathrm{M} \mathrm{KOH}]}\end{array}$ & 627.3 & $0.002-2.5$ & 0.2 & +0.60 & 2019 [283] \\
\hline
\end{tabular}


Table 5. Cont.

\begin{tabular}{|c|c|c|c|c|c|}
\hline $\begin{array}{c}\text { Electrode } \\
\text { [Electrolyte] }\end{array}$ & $\begin{array}{c}\text { Sensitivity } \\
\left(\mu \mathrm{A} \mathrm{mM}^{-1} \mathrm{~cm}^{-2}\right)\end{array}$ & $\begin{array}{l}\text { Linear Range } \\
(\mathrm{mM})\end{array}$ & $\begin{array}{l}\text { LOD } \\
(\mu \mathrm{M})\end{array}$ & $\begin{array}{c}\text { Working } \\
\text { Potential }(\mathrm{V})\end{array}$ & $\begin{array}{c}\text { Year } \\
\text { [Reference] }\end{array}$ \\
\hline $\begin{array}{c}\mathrm{Cu}_{3}(\mathrm{BTC})_{2} \text {-derived } \mathrm{CuO} \\
\text { nanorod } / \mathrm{GCE} \\
{[0.1 \mathrm{M} \mathrm{NaOH}]}\end{array}$ & 1523.5 & Up to 1.25 & 1 & +0.60 & 2019 [62] \\
\hline $\begin{array}{c}\text { Petal-like nano } \mathrm{CuO} / \mathrm{GCE} \\
{[0.05 \mathrm{M} \mathrm{NaOH}]}\end{array}$ & 2634.4 & $5 \times 10^{-4}-2.67$ & 0.26 & +0.65 & 2018 [284] \\
\hline $\begin{array}{l}\text { CuO-PANI-NF/FTO } \\
{[0.1 \mathrm{M} \mathrm{NaOH}]}\end{array}$ & $\begin{array}{l}2800 \\
1359\end{array}$ & $\begin{array}{c}2.5 \times 10^{-4}-0.28 \\
0.28-4.6\end{array}$ & 0.24 & +0.6 & 2018 [120] \\
\hline $\begin{array}{l}\text { CuO biscuits/SPCE } \\
{[0.1 \mathrm{M} \mathrm{NaOH}]}\end{array}$ & 308.7 & Up to 4.03 & 0.1 & +0.50 & 2017 [285] \\
\hline $\begin{array}{l}\mathrm{CuO} \text { NWs/GCE } \\
{[0.05 \mathrm{M} \mathrm{NaOH}]}\end{array}$ & 648.2 & - & 2 & +0.55 & 2014 [286] \\
\hline $\begin{array}{c}\mathrm{CuO}-\mathrm{Cu}_{2} \mathrm{O} / \mathrm{GCE} \\
{[0.1 \mathrm{M} \mathrm{NaOH}]}\end{array}$ & 830 & $0.5-10$ & 0.7 & +0.60 & 2014 [287] \\
\hline $\begin{array}{l}\text { Dandelion-like } \mathrm{CuO} \text { film } / \mathrm{Cu} \text { foils } \\
{[0.1 \mathrm{M} \mathrm{NaOH}]}\end{array}$ & 5368 & $0.005-1.6$ & 1.2 & +0.60 & 2014 [55] \\
\hline $\begin{array}{c}\text { CuO NSs / Au-coated glass } \\
{[0.1 \mathrm{M} \mathrm{NaOH}]}\end{array}$ & 520 & $0.1-10$ & - & +0.50 & 2013 [288] \\
\hline \multicolumn{6}{|c|}{ (c) Electrodes containing $\mathrm{Ni}$ oxides } \\
\hline $\begin{array}{l}\mathrm{NiO} \text { nanostructures/Ni sheets } \\
{[0.1 \mathrm{M} \mathrm{KCl}+0.5 \mathrm{M} \mathrm{NaOH}]}\end{array}$ & 206.9 & $0.1-10$ & 1.16 & +0.55 & 2019 [134] \\
\hline $\begin{array}{l}\mathrm{NiO}-\mathrm{HAC} / \mathrm{GCE} \\
{[0.1 \mathrm{M} \mathrm{NaOH}]}\end{array}$ & 199.9 & $0.01-3.3$ & 1.0 & +0.55 & 2017 [289] \\
\hline $\begin{array}{c}\mathrm{NiO} \text { NPs graphene NSs/GCE } \\
{[0.1 \mathrm{M} \mathrm{NaOH}]}\end{array}$ & 666.7 & $0.005-4.2$ & 5 & +0.50 & 2016 [54] \\
\hline $\begin{array}{c}\text { Mesoporous NWas NiO/3D NF-G } \\
{[0.1 \mathrm{M} \mathrm{NaOH}]}\end{array}$ & 3230 & $0.01-0.2$ & $1 \times 10^{-4}$ & +0.55 & 2016 [290] \\
\hline $\begin{array}{l}\mathrm{NiO}-\mathrm{PPy} / \mathrm{GCE} \\
\text { [0.1 M PBS] }\end{array}$ & $\begin{array}{c}1094.8 \\
62.9\end{array}$ & $\begin{array}{l}0.01-0.5 \\
1-20\end{array}$ & 5.8 & +0.58 & 2015 [122] \\
\hline $\begin{array}{l}\mathrm{NiO} \text { NSks } / \mathrm{GCE} \\
{[0.1 \mathrm{M} \mathrm{NaOH}]}\end{array}$ & 1915 & $0.1-5.0$ & 0.7 & +0.48 & 2015 [291] \\
\hline $\begin{array}{l}\mathrm{NiO} H C s / G C E \\
{[0.1 \mathrm{M} \mathrm{NaOH}]}\end{array}$ & 2476.4 & $0.1-5.0$ & 0.1 & - & 2015 [292] \\
\hline $\begin{array}{c}3 \mathrm{D} \mathrm{NiO} / \mathrm{NF} \\
{[0.5 \mathrm{M} \mathrm{NaOH}]}\end{array}$ & 6657.5 & $0.005-5.5$ & 0.46 & +0.47 & 2013 [293] \\
\hline $\begin{array}{c}\text { NiO-SWCNT/ITO } \\
{[0.1 \mathrm{M} \mathrm{NaOH}]}\end{array}$ & 907 & $0.001-0.9$ & 0.3 & +0.55 & 2013 [294] \\
\hline $\begin{array}{l}\mathrm{NiO} \text { NF-GO/GCE } \\
{[0.1 \mathrm{M} \mathrm{NaOH}]}\end{array}$ & 1100 & $0.002-0.6$ & 0.77 & +0.60 & 2012 [295] \\
\hline
\end{tabular}

${ }^{*}$ All potentials are with respect to the $\mathrm{Ag} / \mathrm{AgCl}$ reference electrode. Abbreviation: 3D NF-G: reduced graphene oxide nanosheets coated 3D nickel foams; BTC: Benzene tricarboxylate; GCE: Glassy carbon electrode; GOH: graphene oxide hydrogels; HAA: Hollow hierarchical architecture; HAC: Heteroatom-enriched activated carbon; HCs: Hollow cage-like nanostructures; HND: Hollow nanododecahedra; ITO: Indium tin oxide; MTs: Microtubes; NF: Nickel foam; NFs: Nanofibers; NPs: Nanoparticles; NSk: Nanoskein; NSs: Nanosheets; NWas: Nanowalls; NWs: Nanowires; PANI: Polyaniline; PBS: Phosphate-buffered saline; PPy: Polypyrrole; OMC: Ordered mesoporous carbon; SPCE: Screen-printed carbon electrode; SWCNT: Single-walled carbon nanotubes.

According to Table 5, generally, $\mathrm{Co}_{3} \mathrm{O}_{4}, \mathrm{CuO}$, and $\mathrm{NiO}$ compounds were used due to the stability issue and these three compounds are the necessary media as the electroactive sites for the electro-oxidation of glucose (please refer to the mechanisms in Table 1). In addition to the aforementioned three most-seen major compounds, other compounds, such as $\mathrm{Fe}_{2} \mathrm{O}_{3}$ and $\mathrm{SnO}_{2}$, are also used as the electrocatalysts for the electro-oxidation of glucose. 
Moreover, some of the studies integrated various metallic oxides, such as the $\mathrm{CuO}-\mathrm{NiO}$ compound [296] and the $\mathrm{Co}_{3} \mathrm{O}_{4}-\mathrm{NiCO}_{2} \mathrm{O}_{4}$ [297] compound, which are used for further enhancing the performance of the electrodes for the electro-oxidation of glucose.

\section{Electroactive Materials of Hydroxide Compounds}

Not only the aforementioned metallic oxides widely were used for the electro-oxidation of glucose, but also the metallic hydroxide compounds. According to the reaction mechanisms in Table 1, it could be found that the metallic hydroxide compounds are also crucial media for the electro-oxidation of glucose by the electrochemical technique. The metallic hydroxide compounds are therefore utilized directly as the electrocatalysts for the electrooxidation of glucose. Since the reaction mechanisms are already shown and explained in Table 1, the explanations for the reaction mechanisms are left out in this section. Some of the literature concerning the metallic hydroxide compounds within this decade are listed and compared in Table 6 .

Table 6. The electrodes for the sensing of glucose by the transition metal hydroxides. The performances are compared in terms of sensitivity, linear range, limit of detection (LOD), and working potential. The working potentials are based on the reference electrode of $\mathrm{Ag} / \mathrm{AgCl}$.

\begin{tabular}{|c|c|c|c|c|c|}
\hline $\begin{array}{c}\text { Electrode } \\
\text { [Electrolyte] }\end{array}$ & $\begin{array}{c}\text { Sensitivity } \\
\left(\mu \mathrm{A} \mathrm{mM}^{-1} \mathrm{~cm}^{-2}\right)\end{array}$ & $\begin{array}{c}\text { Linear } \\
\text { Range (mM) }\end{array}$ & $\begin{array}{l}\text { LOD } \\
(\mu \mathrm{M})\end{array}$ & $\begin{array}{c}\text { Working } \\
\text { Potential (V) * }\end{array}$ & $\begin{array}{c}\text { Year } \\
\text { [Reference] }\end{array}$ \\
\hline $\begin{array}{c}\mathrm{Co}(\mathrm{OH})_{2} \text { NTAs } / \mathrm{CC} \\
{[0.1 \mathrm{M} \mathrm{NaOH}]}\end{array}$ & 2770 & $0.001-0.6$ & 0.5 & +0.50 & 2017 [298] \\
\hline $\begin{array}{c}\text { CoOOH NSAs/GCE } \\
{[0.1 \mathrm{M} \mathrm{NaOH}]}\end{array}$ & 526.8 & $0.003-1.11$ & 1.37 & +0.52 & 2015 [299] \\
\hline $\begin{array}{c}\text { CoOOH NSs/Co foil } \\
{[0.1 \mathrm{M} \mathrm{NaOH}]}\end{array}$ & $\begin{array}{l}967 \\
341\end{array}$ & $\begin{array}{l}0.01-0.5 \\
0.03-0.7\end{array}$ & $\begin{array}{l}10.6 \\
30.9\end{array}$ & $\begin{array}{l}+0.50 \\
+0.40\end{array}$ & 2012 [124] \\
\hline $\begin{array}{l}\mathrm{Cu}(\mathrm{OH})_{2} \mathrm{NTs} \\
{[0.1 \mathrm{M} \mathrm{NaOH}]}\end{array}$ & 418 & Up to 3.0 & 0.5 & +0.45 & 2013 [300] \\
\hline $\begin{array}{c}\mathrm{Cu}(\mathrm{OH})_{2} \mathrm{NFs} / \mathrm{Cu} \text { foil } \\
{[0.1 \mathrm{M} \mathrm{NaOH}]}\end{array}$ & 2159.2 & $0-6.0$ & 9.0 & +0.50 & 2012 [301] \\
\hline $\begin{array}{c}\mathrm{Ni}(\mathrm{OH})_{2} / 3 \mathrm{DGF} \\
{[0.2 \mathrm{M} \mathrm{NaOH}]}\end{array}$ & 2366 & Up to 2.2 & 0.32 & +0.46 & 2019 [302] \\
\hline $\begin{array}{c}\mathrm{Ni}(\mathrm{OH})_{2} \mathrm{NSs}-\mathrm{NF} / \mathrm{GCE} \\
{[0.2 \mathrm{M} \mathrm{NaOH}]}\end{array}$ & $\begin{array}{l}1097 \\
1130\end{array}$ & $\begin{array}{c}0.1-2.5 \\
2-40\end{array}$ & 1.0 & +0.51 & 2015 [303] \\
\hline $\begin{array}{c}\mathrm{Ni}(\mathrm{OH})_{2} \text { NFks@oPPyNW/Graphite } \\
{[0.1 \mathrm{M} \mathrm{NaOH}]}\end{array}$ & 1049 & $0.001-3.86$ & 0.3 & +0.54 & 2015 [304] \\
\hline $\begin{array}{c}\mathrm{Ni}(\mathrm{OH})_{2} \mathrm{NPs} / \text { graphene } \\
{[0.1 \mathrm{M} \mathrm{NaOH}]}\end{array}$ & 2400 & $0.001-15$ & 0.53 & +0.53 & 2014 [305] \\
\hline $\begin{array}{c}\mathrm{Ni}(\mathrm{OH})_{2} \mathrm{NPs} / \mathrm{NF} \\
{[0.2 \mathrm{M} \mathrm{NaOH}]}\end{array}$ & 1950.3 & Up to 6.0 & 0.16 & +0.45 & 2014 [41] \\
\hline
\end{tabular}

* All potentials are with respect to the Ag/AgCl reference electrode. Abbreviation: 3DGF: Three-dimensional graphene@nickel foam; NF: Nickel foam; NFs: Nanoflowers; NFks: Nanoflakes; NPs: Nanoparticles; NSAs: Nanosheet arrays; NSs: Nanosheets; NTAs/CC: Nanotube arrays grown on carbon cloth; NTs: Nanotubes; oPPyNW: Over-oxidized polypyrrole nanowires.

Metallic hydroxides, such as $\mathrm{Co}(\mathrm{OH})_{2}, \mathrm{CoOOH}, \mathrm{Cu}(\mathrm{OH})_{2}$, and $\mathrm{Ni}(\mathrm{OH})_{2}$, are frequently used materials. Similar to the transition metals and the transition metallic oxides, the transition metallic hydroxide compounds (i.e., $\mathrm{M}(\mathrm{OH})_{2}$ and $\mathrm{MOOH}$ ) also possess high sensitivity. However, the operation potential is higher than that of the noble metal ones (Table 2) due to the low electrical conductivity of these materials. In addition to the single-phase of the transition metallic hydroxides, some dual-phase compounds, such as $\mathrm{Ni}(\mathrm{OH})_{2}-\mathrm{NiO}$ [306], $\mathrm{Ni}(\mathrm{OH})_{2}-\mathrm{TiO}_{2}$ [307], $\mathrm{CuO}-\mathrm{Ni}(\mathrm{OH})_{2}$ [308], $\mathrm{Co}_{3} \mathrm{O}_{4}-\mathrm{Ni}(\mathrm{OH})_{2}$ [309], and so forth, have also been studied. The variety of the electroactive catalysts for the electro-oxidation of glucose could be greatly enhanced by integrating the (1) mono-metallic 
materials (Section 6), (2) bi-metallic materials (Section 7), (3) metallic oxides (Section 8), and (4) metallic hydroxides (Section 9). Therefore, the performances of the electroactive catalysts could be balanced by different synergistic effects (i.e., anti-poisoning effect) among the materials.

\section{Electroactive Materials of Metals and Their Derivatives}

As mentioned in the previous sections, there are a great variety of combinations of electro-catalytic active materials for enhancing the detection performances of glucose. The metallic materials and the metallic derivatives have been discussed in the previous sections. In this section, the issue presented by the metal-metallic oxide is discussed. Some of the metal-metal derivative composites have been studied, such as Ag-NiO [46,57], $\mathrm{Cu}-\mathrm{CuO}$ [38], $\mathrm{Ag}-\mathrm{CuO}$ [44], $\mathrm{Cu}-\mathrm{CuO}-\mathrm{ZnO}$ [45], and $\mathrm{Co}-\mathrm{CoOOH}$ [124]. However, in the following section, a less studied composite of the $\mathrm{Au}-\mathrm{TiO}_{2}$ composite [42,47], which was synthesized on the polyaniline (PANI) supporting material, is discussed.

\subsection{Electrocatalysts of the Au Nanoparticles-TiO}

In the previous sections, the topics of (1) mono-metallic materials, (2) bi-metallic materials, (3) metallic oxides, and (4) metallic hydroxides have been reviewed. As mentioned previously, with the combination of the materials, property balance among different materials could result in a constructive synergistic effect and bring about the enhanced performances for the electro-oxidation of glucose. The Au nanoparticle (NP)- $\mathrm{TiO}_{2}$, which is the combination between the mono-metallic material and the metallic oxide, is discussed in this section and the following sections.

As explained in Section 6, metallic Au, which is considered a promising material for the electro-oxidation of glucose, has been widely used as the electrocatalyst. On the other hand, $\mathrm{TiO}_{2}$ is not a frequently used material for the electro-oxidation of glucose. However, by combining these two materials, the performances of the electro-oxidation of glucose have been greatly improved [42,47]. The enhanced behavior could be ascribed to the following two reasons.

Firstly, with the decoration of $\mathrm{TiO}_{2}$, a spill-over effect of the $\mathrm{OH}^{-}$ions from the $\mathrm{TiO}_{2}$ surface to the $\mathrm{Au}$ NPs was proposed since $\mathrm{TiO}_{2}$ is known as a hydrophilic material [310]. High concentration of $\mathrm{OH}^{-}$diffused from the surface of $\mathrm{TiO}_{2}$ to the surface of $\mathrm{Au}$ NPs. Hence, a great amount of the crucial media $\mathrm{AuOH}_{\text {ads }}$ could be generated on the surface of the metallic Au NPs [42,47]. Secondly, it was further found that, while the $\mathrm{TiO}_{2}$ amount went beyond its saturation concentration on the electrode surface, the redistribution of the $\mathrm{TiO}_{2}$ particles took place on the electrode surface, revealing the electroactive sites to the glucose, and resulting in a large surface area of the electroactive catalyst. The redistribution could be ascribed to the famous coffee ring effect [311], which occurs during the drying process. Eventually, the high surface area of the electroactive sites led to the efficient usage of the noble metals by the facile immersion-drying process and brought about cost-effective processes. The abovementioned two mechanisms are illustrated and shown in Figure 15.

Since $\mathrm{TiO}_{2}$ is known as a hydrophilic material, it could attract the $\mathrm{OH}^{-}$and/or the $\mathrm{H}_{2} \mathrm{O}$ molecules in the electrolyte (left-hand side illustration of Figure 15a). Due to the high concentration of the $\mathrm{OH}^{-}$on the $\mathrm{TiO}_{2}$ surface, the $\mathrm{OH}^{-}$diffuses to the surface of the adjacent Au NPs (right-hand side illustration of Figure 15a). Hence, the amount of the crucial electroactive site $\mathrm{AuOH}_{\text {ads }}$ for the electro-oxidation of glucose could be promoted. The redistribution phenomenon of the oxide particles is illustrated in Figure $15 \mathrm{~b}$. Prior to the redistribution, there was an aggregation of the $\mathrm{TiO}_{2}$ particles and the clustered $\mathrm{TiO}_{2}$ impeded the electrochemical reactions between Au NPs and the glucose (left-hand side illustration of Figure 15b). The red cross symbols indicate the unavailable electroactive sites due to the hindrance of the $\mathrm{TiO}_{2}$ particles. With the assistance of the redistribution, the Au NPs could be revealed to the glucose molecule in the electrolyte (right-hand side illustration of Figure 15b). The efficiency for the usage of the Au NPs could be enhanced 
accordingly. The aforementioned mechanisms are the possible reasons for the enhancement of the performance of the electro-oxidation of glucose.

\section{(a) Spill-over effect}

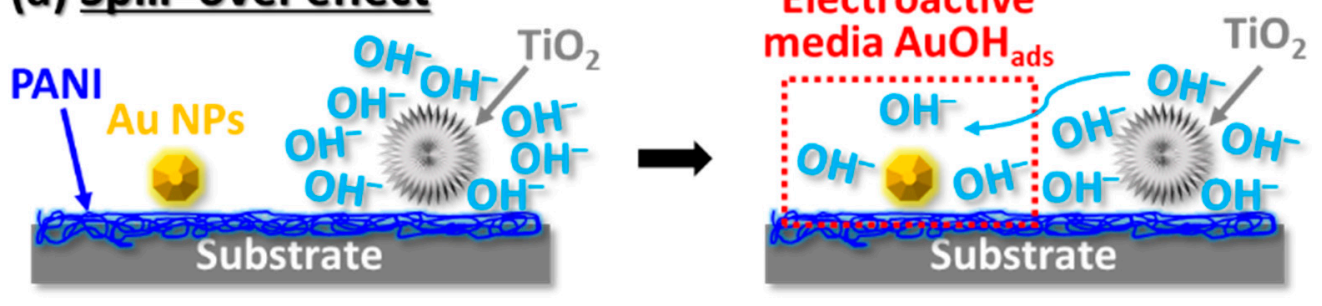

\section{(b) Re-distribution phenomenon}
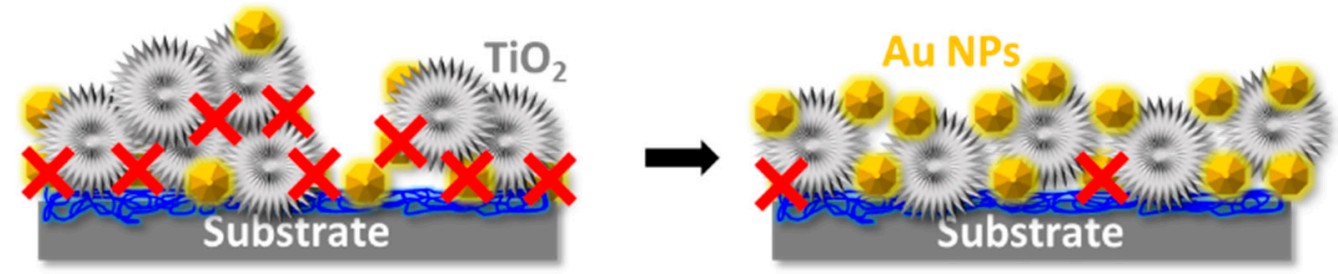

Figure 15. (a) Spill-over effect of the $\mathrm{OH}^{-}$from the $\mathrm{TiO}_{2}$ particles to the Au NPs. (b) Redistribution phenomenon of the $\mathrm{TiO}_{2}$ particles under its supersaturated concentration. (The red cross symbols indicate the unavailable electroactive sites due to the hindrance of the $\mathrm{TiO}_{2}$ particles).

\subsection{Strategies for Enhancement of Performances of the Electrodes}

To enhance the hydrophilicity of oxides and also to figure out the mechanisms, manipulating the hydrophilicity of oxides could be a practical method. It has been reported that the hydrophilicity of $\mathrm{TiO}_{2}$ particles could be tuned by the sol-gel method [310], UV illumination [312], and ultrasonic treatment [313]. A high amount of the $\mathrm{AuOH}_{\mathrm{ads}}$ is expected to be generated by enhancing the hydrophilicity of the adjacent $\mathrm{TiO}_{2}$ particles. While lowering down the hydrophilicity of the $\mathrm{TiO}_{2}$ particles, the current response from the electro-oxidation of glucose could be diminished. Hence, the mechanism could be clarified via the manipulation of the hydrophilicity of the $\mathrm{TiO}_{2}$ particles. An illustration for elucidating the aforementioned methodology is shown in Figure 16a.

On the other hand, concerning the issue of the redistribution of the oxide particles, another strategy has been discussed in the following to enlarge the surface area of the electroactive sites by taking the advantage of the redistribution phenomenon of the oxide particles. It has been reported that the flower-like structured $\mathrm{ZnO}$ could be synthesized by the electrochemical deposition and its morphology could be controlled by the additives, such as the $\mathrm{H}_{2} \mathrm{O}_{2}$ and the $\mathrm{Cl}^{-}$ion [314]. The methodologies used in this literature for the manipulation of the morphologies could also be applied to other oxides, such as $\mathrm{TiO}_{2}$. By taking the advantage of the flower-like oxides, it is believed that the surface area of the electroactive sites could be promoted due to the enhanced stability and surface area of the metallic NPs on the flower-like oxides. An illustration for elucidating the mechanism is shown in Figure 16b.

The integrations of the Au NPs/ball-like oxide particles and the Au NPs/flower-like oxide particles are shown in Figure 16b. In the case of the Au NPs/ball-like particle (left-hand side illustration of Figure 16b), there is some loss of the Au NPs during the aforementioned redistribution process and the measurement processes for the electrooxidation of glucose. The yellow arrows indicate the loss of the Au NPs from the oxide to the environment. In other words, the stability of Au NPs on the ball-like particle is insufficient. On the other hand, by manipulating the morphologies of the oxides into the flower-like structure, it is possible that the Au NPs could be stabilized between the "flower 
petals" (right-hand side illustration of Figure 16b). Accordingly, the loss of the Au NPs during the redistribution process and the measurement processes for the electro-oxidation of glucose could be reduced.

\section{(a) Hydrophilicity controlling of oxide particles}

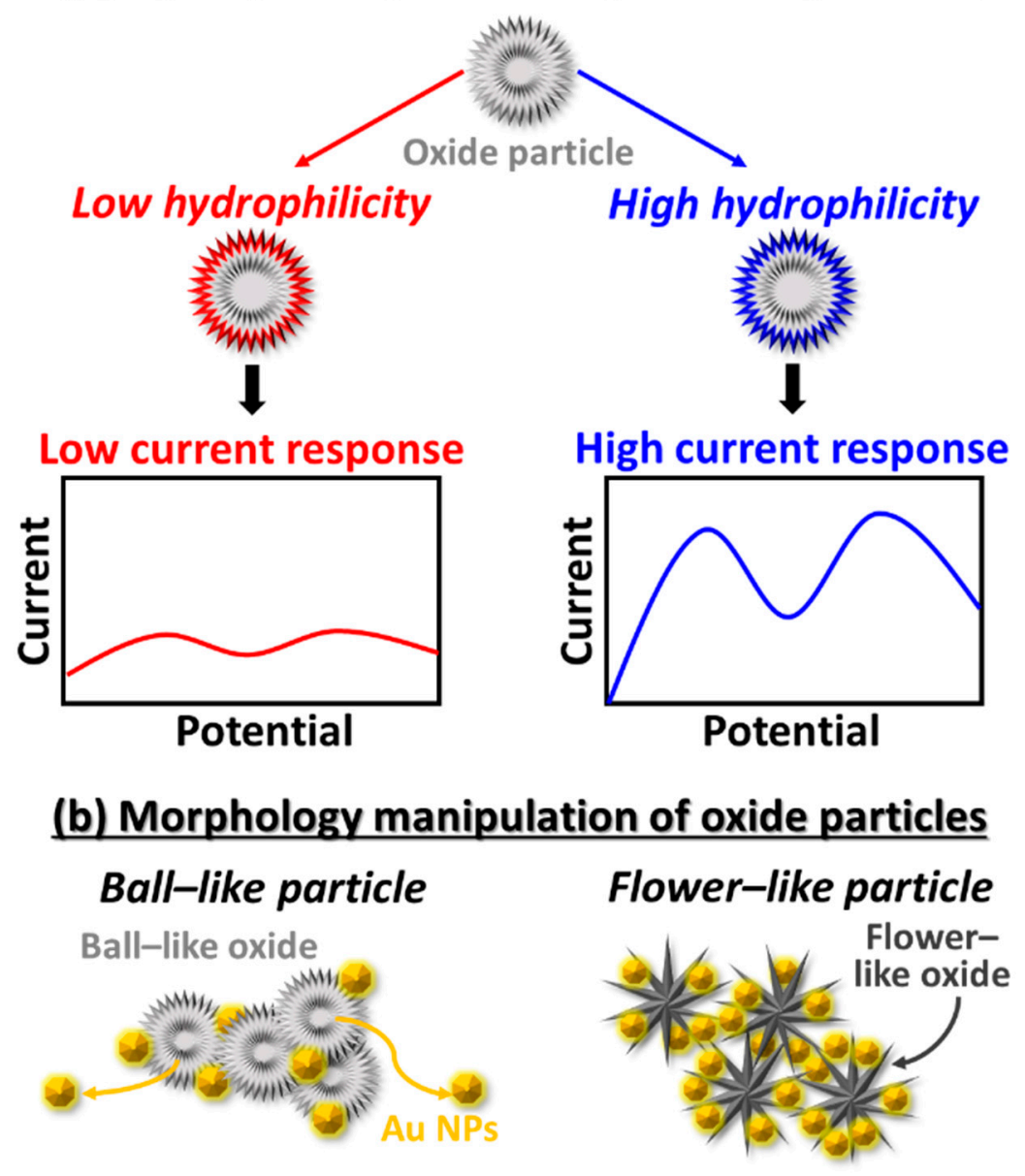

Figure 16. (a) Combination of the ball-like oxide and the Au NPs. (b) Integration of the flower-like oxide and the Au NPs. (The yellow arrows indicate the loss of the Au NPs from the oxide to the environment).

In addition to the aforementioned enhancement in the stabilization of the Au NPs electrocatalyst, there is a further advantage, which could be brought along with the usage of the flower-like structured oxides. Since the porosity of the flower-like oxide is higher than that of the ball-like oxide, the diffusion of glucose into the composite materials could be less interfered with. That is to say, the hindrance for the electro-oxidation of glucose from the oxide could be reduced by using flower-like oxide particles. Therefore, controlling the morphology of the oxide particles could be a promising method for the enhancement of electrode stability, reduction of the usage of noble metal, and enhancement of the current response from the electro-oxidation of glucose.

In this section, two possible strategies for the enhancement of the performances of the electro-oxidation of glucose and for the clarification of mechanisms involved have been proposed. The less-studied yet promising $\mathrm{Au} \mathrm{NPs-TiO} 2$ composites for the electro-oxidation of glucose have shown great potential in the glucose detection community.

\section{Conclusions}

In this article, a comprehensive review concerning the electroactive materials for the electro-oxidation of glucose has been conducted. General introductions and comparisons 
to the electro-oxidation of glucose in an enzymatic manner and the non-enzymatic manner were presented, and the fundamentals of the promising electrochemical technique for glucose detection have also been explained.

The classification of the electrocatalysts has been divided into five different materials, namely the (1) most fundamental materials of the prototype mono-metallic electrocatalyst (i.e., $\mathrm{Au}, \mathrm{Pt}, \mathrm{Ni}$, and $\mathrm{Cu}$ ), the (2) bi-metallic materials (i.e., $\mathrm{Au}-\mathrm{Pt}, \mathrm{Pt}-\mathrm{Ni}$, and $\mathrm{Cu}-\mathrm{Ni}$ ), the (3) metallic-oxide compounds (i.e., $\mathrm{Co}_{3} \mathrm{O}_{4}, \mathrm{CuO}$, and $\mathrm{NiO}$ ), the (4) metallichydroxide compounds $\left(\mathrm{CoOOH}, \mathrm{Cu}(\mathrm{OH})_{2}\right.$, and $\left.\mathrm{Ni}(\mathrm{OH})_{2}\right)$, and the (5) combinations of the metallic materials/metallic-derivative compounds (i.e., $\mathrm{Au}-\mathrm{TiO}_{2}, \mathrm{Ag}-\mathrm{NiO}, \mathrm{Cu}-\mathrm{CuO}$, and $\mathrm{Co}-\mathrm{CoOOH}$ ) have been reviewed through in this article.

Based on the different materials, the mechanisms for the electro-oxidation of glucose have been explained and compared. The performances of the aforementioned five material systems within this decade have been compared in terms of sensitivity, linear range, the limit of detection (LOD), and operation potential.

In addition, some practicable strategies and ideas have been proposed, such as (1) the atomic deposition of the metals or alloys for trading-off the various properties in the electroactive materials, (2) the manipulation of hydrophilicity and the redistribution phenomenon of oxide particles, and (3) the morphology controlling of the oxide particles for the improvement of the long-term stability of the electrodes for the electro-oxidation of glucose. In addition to the aforementioned general introductions, mechanisms, materials, and strategies, a comprehensive review of the glucose sensor devices within this decade has also been conducted.

Author Contributions: Conceptualization, W.-T.C.; methodology, W.-T.C.; software, W.-T.C.; validation, W.-T.C., H.T.; formal analysis, W.-T.C.; investigation, W.-T.C.; resources, W.-T.C., T.-F.M.C., M.S., A.T.-M., H.T.; data curation, W.-T.C.; writing-original draft preparation, W.-T.C.; writing-review and editing, H.T.; visualization, W.-T.C.; supervision, H.H., A.T.-M., and H.T.; project administration, M.S.; funding acquisition, T.-F.M.C., M.S., and H.T. All authors have read and agreed to the published version of the manuscript.

Funding: This work is supported by the Japan Society for the Promotion of Science (JSPS) ((1) KAKENHI Grant Number 19F19048, (2) KAKENHI Grant Number JP21359942, and (3) KAKENHI Grant Number JP21416294).

Institutional Review Board Statement: Not applicable.

Informed Consent Statement: Not applicable.

Data Availability Statement: Data sharing not applicable.

Conflicts of Interest: The authors declare no conflict of interest.

\section{References}

1. International Diabetes Federation. IDF Diabetes Atlas, 8th ed.; International Diabetes Federation: Brussels, Belgium, 2017.

2. Papatheodorou, K.; Banach, M.; Bekiari, E.; Rizzo, M.; Edmonds, M. Complications of Diabetes 2017. J. Diabetes Res. 2018, 2018, 3086167. [CrossRef]

3. Fox, C.S.; Coady, S.; Sorlie, P.D.; Levy, D.; Meigs, J.B.; D’Agostino, R.B.; Wilson, P.W.F.; Savage, P.J. Trends in cardiovascular complications of diabetes. JAMA 2004, 292, 2495-2499. [CrossRef] [PubMed]

4. Nathan, D.M. Long-term complications of diabetes mellitus. N. Engl. J. Med. 1993, 328, 1676-1685. [CrossRef] [PubMed]

5. Nilsson, H.; Akerlund, A.C.; Mosbach, K. Determination of glucose, urea and penicillin using enzyme-pH-electrodes. Biochem. Biophys. Acta 1973, 320, 529. [CrossRef]

6. Updike, S.J.; Hicks, G.P. The Enzyme Electrode. Nature 1067, 214, 986. [CrossRef] [PubMed]

7. Clark, L.C., Jr.; Lyons, C. Electrode systems for continuous monitoring in cardiovascular surgery. Ann. N. Y. Acad. Sci. 1962, 102, 29. [CrossRef]

8. Hwang, D.W.; Lee, S.; Seo, M.; Chung, T.D. Recent advances in electrochemical non-enzymatic glucose sensors-A review. Anal. Chim. Acta 2018, 1033, 1-34. [CrossRef]

9. Wang, G.; He, X.; Wang, L.; Gu, A.; Huang, Y.; Fang, B.; Geng, B.; Zhang, X. Non-enzymatic electrochemical sensing of glucose. Microchim. Acta 2013, 180, 161-186. [CrossRef]

10. Park, S.; Boo, H.; Chung, T.D. Electrochemical non-enzymatic glucose sensors. Anal. Chim. Acta 2006, 556, 46-57. [CrossRef] 
11. Bankar, S.B.; Bule, M.V.; Singhal, R.S.; Ananthanarayan, L. Glucose oxidase-An overview. Biotechnol. Adv. 2009, $27,489-501$. [CrossRef]

12. Cao, L.; Ye, J.; Tong, L.; Tang, B. A New Route to the Considerable Enhancement of Glucose Oxidase (GOx) Activity: The Simple Assembly of a Complex from CdTe Quantum Dots and GOx, and Its Glucose Sensing. Chem. Eur. J. 2008, 14, 9633-9640. [CrossRef]

13. Mala Ekanayake, E.M.I.; Preethichandra, D.M.G.; Kaneto, K. Polypyrrole nanotube array sensor for enhanced adsorption of glucose oxidase in glucose biosensors. Biosens. Bioelectron. 2007, 23, 107-113. [CrossRef]

14. Holt, R.E.; Cotton, T.M. Surface-Enhanced Resonance Raman and Electrochemical Investigation of Glucose Oxidase Catalysis at a Silver Electrode. J. Am. Chem. Soc. 1989, 111, 2815-2821. [CrossRef]

15. Foulds, N.C.; Lowe, C.R. Immobilization of Glucose Oxidase in Ferrocene-Modified Pyrrole Polymers. Anal. Cham. 1998, 60, 2473-2478. [CrossRef] [PubMed]

16. Degani, Y.; Heller, A. Direct Electrical Communication between Chemically Modified Enzymes and Metal Electrodes. 1. Electron Transfer from Glucose Oxidase to Metal Electrodes via Electron Relays, Bound Covalently to the Enzyme. J. Phys. Chem. 1987, 91, 1285-1289. [CrossRef]

17. Abellán-Llobregat, A.; Jeerapan, I.; Bandodkar, A.; Vidal, L.; Canals, A.; Wang, J.; Morallón, E. A stretchable and screen-printed electrochemical sensor for glucose determination in human perspiration. Biosens. Bioelectron. 2017, 91, 885-891. [CrossRef] [PubMed]

18. Ferri, S.; Kojima, K.; Sode, K. Review of Glucose Oxidases and Glucose Dehydrogenases: A Bird's Eye View of Glucose Sensing Enzymes. J. Diabetes Sci. Technol. 2011, 5, 1068-1076. [CrossRef]

19. Wong, C.M.; Wong, K.H.; Chen, X.D. Glucose oxidase: Natural occurrence, function, properties and industrial applications. Appl. Microbiol. Biotechnol. 2008, 78, 927-938. [CrossRef] [PubMed]

20. Malitesta, C.; Palmisano, F.; Torsi, L.; Zambonin, P.G. Glucose Fast-Response Amperometric Sensor Based on Glucose Oxidase Immobilized in an Electropolymerized Poly (o-phenyienediamine) Film. Anal. Chem. 1990, 62, 2735-2740. [CrossRef] [PubMed]

21. Lee, H.; Hong, Y.J.; Baik, S.; Hyeon, T.; Kim, D.-H. Enzyme-Based Glucose Sensor: From Invasive to Wearable Device. Adv. Healthc. Mater. 2018, 7, 1701150. [CrossRef] [PubMed]

22. Martin, A.F.; Nieman, T.A. Glucose quantitation using an immobilized glucose dehydrogenase enzyme reactor and a tris (2,2'-bipyridyl) ruthenium (II) chemiluminescent sensor. Anal. Chim. Acta 1993, 281, 475-481. [CrossRef]

23. Ye, L.; Hámmerle, M.; Olsthoorn, A.J.J.; Schuhmann, W.; Schmidt, H.-L.; Duine, J.A.; Heller, A. High Current Density “Wired” Quinoprotein Glucose Dehydrogenase Electrode. Anal. Chem. 1993, 65, 238-241. [CrossRef]

24. D'Costa, E.J.; Higgins, I.J.; Turner, A.P.F. Quinoprotein glucose dehydrogenase and its application in an amperometric glucose sensor. Biosensors 1986, 2, 71-87. [CrossRef]

25. Wilson, R.; Turner, A.P.F. Glucose oxidase: An ideal enzyme. Biosens. Bioelectron. 1992, 7, 165-185. [CrossRef]

26. Harris, J.M.; Reyes, C.; Lopez, G.P. Causes of Glucose Oxidase Instability in In Vivo Biosensing: A Brief Review. J. Diabetes Sci. Technol. 2013, 7, 1030-1038. [CrossRef] [PubMed]

27. Umaña, M.; Waller, J. Protein-Modified Electrodes. The Glucose Oxidase/Polypyrrole System. Anal. Chem. 1986, 58, 2979-2983. [CrossRef]

28. Zdarta, J.; Pinelo, M.; Jesionowski, T.; Meyer, A. Upgrading of biomass monosaccharides by immobilized glucose dehydrogenase and xylose dehydrogenase. ChemCatChem 2018, 10, 5164-5173. [CrossRef]

29. Sode, K.; Tsugawa, W.; Yamazaki, T.; Watanabe, M.; Ogasawara, N.; Tanaka, M. A novel thermostable glucose dehydrogenase varying temperature properties by altering its quaternary structures. Enzyme Microb. Technol. 1996, 19, 82-85. [CrossRef]

30. Deep, A.; Tiwari, U.; Kumar, P.; Mishra, V.; Jain, S.C.; Singh, N.; Kapur, P.; Bharadwaj, L.M. Immobilization of enzyme on long period grating fibers for sensitive glucose detection. Biosens. Bioelectron. 2012, 33, 190-195. [CrossRef]

31. Zhang, Z.; Liu, H.; Deng, J. A Glucose Biosensor Based on Immobilization of Glucose Oxidase in Electropolymerized oAminophenol Film on Platinized Glassy Carbon Electrode. Anal. Chem. 1996, 68, 1632-1638. [CrossRef]

32. Demura, M.; Asakura, T.; Kuroo, T. Immobilization of biocatalysts with bombyx mori silk fibroin by several kinds of physical treatment and its application to glucose sensors. Biosensors 1989, 4, 361-372. [CrossRef]

33. Jönsson, G.; Gorton, L. An amperometric glucose sensor made by modification of a graphite electrode surface with immobilized glucose oxidase and adsorbed mediator. Biosensors 1985, 1, 355-368. [CrossRef]

34. Ye, J.-S.; Chen, C.-W.; Lee, C.-L. Pd nanocube as non-enzymatic glucose sensor. Sens. Actuators B Chem. 2015, 208, 569-574. [CrossRef]

35. Luo, J.; Jiang, S.; Zhang, H.; Jiang, J.; Liu, X. A novel non-enzymatic glucose sensor based on Cu nanoparticle modified graphene sheets electrode. Anal. Chim. Acta 2012, 709, 47-53. [CrossRef] [PubMed]

36. Karimi-Maleh, H.; Cellat, K.; Arıkan, K.; Savk, A.; Karimi, F.; Şen, F. Palladium-Nickel nanoparticles decorated on FunctionalizedMWCNT for high precision non-enzymatic glucose sensing. Mater. Chem. Phys. 2020, 250, 123042. [CrossRef]

37. Li, H.; Guo, C.-Y.; Xu, C.-L. A highly sensitive non-enzymatic glucose sensor based on bimetallic Cu-Ag superstructures. Biosens. Bioelectron. 2015, 63, 339-346. [CrossRef] [PubMed]

38. Zhuang, Z.; Su, X.; Yuan, H.; Sun, Q.; Xiao, D.; Choi, M.M.F. An improved sensitivity non-enzymatic glucose sensor based on a $\mathrm{CuO}$ nanowire modified Cu electrode. Analyst 2008, 133, 126-132. [CrossRef] 
39. Liu, S.; Yu, B.; Zhang, T. A novel non-enzymatic glucose sensor based on NiO hollow spheres. Electrochim. Acta 2013, $102,104-107$. [CrossRef]

40. Guo, C.; Zhang, X.; Huo, H.; Xu, C.; Han, X. $\mathrm{Co}_{3} \mathrm{O}_{4}$ microspheres with free-standing nanofibers for high performance nonenzymatic glucose sensor. Analyst 2013, 138, 6727-6731. [CrossRef]

41. Zhang, Y.; Zheng, D.; Liu, S.; Qin, S.; Sun, X.; Wang, Z.; Qin, C.; Li, Y.; Zhou, J. Flexible porous Ni $(\mathrm{OH})_{2}$ nanopetals sandwiches for wearable non-enzyme glucose sensors. Appl. Surf. Sci. 2021, 552, 149529. [CrossRef]

42. Chiu, W.-T.; Chang, T.-F.M.; Sone, M.; Tixier-Mita, A.; Toshiyoshi, H. Electrocatalytic activity enhancement of Au NPs-TiO 2 electrode via a facile redistribution process towards the non-enzymatic glucose sensors. Sens. Actuators B Chem. 2020, $319,128279$. [CrossRef]

43. Su, Y.; Guo, H.; Wang, Z.; Long, Y.; Li, W.; Tu, Y. Au@Cu ${ }_{2} \mathrm{O}$ core-shell structure for high sensitive non-enzymatic glucose sensor. Sens. Actuators B Chem. 2018, 255, 2510-2519. [CrossRef]

44. Zheng, B.; Liu, G.; Yao, A.; Xiao, Y.; Du, J.; Guo, Y.; Xiao, D.; Hu, Q.; Choi, M.M.F. A sensitive AgNPs/CuO nanofibers non-enzymatic glucose sensor based on electrospinning technology. Sens. Actuators B Chem. 2014, 195, 431-438. [CrossRef]

45. Yoon, S.S.; Ramadoss, A.; Saravanakumar, B.; Kim, S.J. Novel Cu/CuO/ZnO hybrid hierarchical nanostructures for non-enzymatic glucose sensor application. J. Electroanal. Chem. 2014, 717-718, 90-95.

46. Ding, Y.; Wang, Y.; Su, L.; Zhang, H.; Lei, Y. Preparation and characterization of NiO-Ag nanofibers, NiO nanofibers, and porous Ag: Towards the development of a highly sensitive and selective non-enzymatic glucose sensor. J. Mater. Chem. 2010, 20, 9918-9926. [CrossRef]

47. Chiu, W.-T.; Chang, T.-F.M.; Sone, M.; Tixier-Mita, A.; Toshiyoshi, H. Roles of $\mathrm{TiO}_{2}$ in the highly robust Au nanoparticles-TiO 2 modified polyaniline electrode towards non-enzymatic sensing of glucose. Talanta 2020, 212, 120780. [CrossRef]

48. Baghayeri, M.; Amiri, A.; Farhadi, S. Development of non-enzymatic glucose sensor based on efficient loading Ag nanoparticles on functionalized carbon nanotubes. Sens. Actuators B Chem. 2016, 225, 354-362. [CrossRef]

49. Wang, Q.; Cui, X.; Chen, J.; Zheng, X.; Liu, C.; Xue, T.; Wang, H.; Jin, Z.; Qiao, L.; Zheng, W. Well-dispersed palladium nanoparticles on graphene oxide as a non-enzymatic glucose sensor. RSC Adv. 2012, 2, 6245-6249. [CrossRef]

50. Wu, H.-X.; Cao, W.-M.; Li, Y.; Liu, G.; Wen, Y.; Yang, H.-F.; Yang, S.-P. In situ growth of copper nanoparticles on multiwalled carbon nanotubes and their application as non-enzymatic glucose sensor materials. Electrochim. Acta 2010, 55, 3734-3740. [CrossRef]

51. Yang, J.; Jiang, L.-C.; Zhang, W.-D.; Gunasekaran, S. A highly sensitive non-enzymatic glucose sensor based on a simple twostep electrodeposition of cupric oxide $(\mathrm{CuO})$ nanoparticles onto multi-walled carbon nanotube arrays. Talanta 2010, 82, 25-33. [CrossRef] [PubMed]

52. Ahmad, R.; Ahn, M.-S.; Hahn, Y.-B. Fabrication of a non-enzymatic glucose sensor field-effect transistor based on verticallyoriented $\mathrm{ZnO}$ nanorods modified with $\mathrm{Fe}_{2} \mathrm{O}_{3}$. Electrochem. Commun. 2017, 77, 107-111. [CrossRef]

53. Iwu, K.O.; Lombardo, A.; Sanz, R.; Scirè, S.; Mirabella, S. Facile synthesis of Ni nanofoam for flexible and low-cost non-enzymatic glucose sensing. Sens. Actuators B Chem. 2016, 224, 764-771. [CrossRef]

54. Zeng, G.; Li, W.; Ci, S.; Jia, J.; Wen, Z. Highly Dispersed NiO Nanoparticles Decorating graphene Nanosheets for Non-enzymatic Glucose Sensor and Biofuel Cell. Sci. Rep. 2016, 6, 36454. [CrossRef]

55. Li, K.; Fan, G.; Yang, L.; Li, F. Novel ultrasensitive non-enzymatic glucose sensors based on controlled flower-like CuO hierarchical films. Sens. Actuators B Chem. 2014, 199, 175-182. [CrossRef]

56. Xu, H.; Xia, C.; Wang, S.; Han, F.; Akbari, M.K.; Hai, Z.; Zhuiykov, S. Electrochemical non-enzymatic glucose sensor based on hierarchical 3D $\mathrm{Co}_{3} \mathrm{O}_{4} / \mathrm{Ni}$ heterostructure electrode for pushing sensitivity boundary to a new limit. Sens. Actuators B Chem. 2018, 267, 93-103. [CrossRef]

57. Ngo, Y.-L.T.; Hoa, L.T.; Chung, J.S.; Hur, S.H. Multi-dimensional Ag/NiO/reduced graphene oxide nanostructures for a highly sensitive non-enzymatic glucose sensor. J. Alloys Compd. 2017, 712, 742-751. [CrossRef]

58. Sedighi, A.; Montazer, M.; Mazinani, S. Synthesis of wearable and flexible $\mathrm{NiP}_{0.1}-\mathrm{SnO}_{\mathrm{x}} / \mathrm{PANI} / \mathrm{CuO} /$ cotton towards a nonenzymatic glucose sensor. Biosens. Bioelectron. 2019, 135, 192-199. [CrossRef]

59. Stepniowski, W.J.; Misiolek, W.Z. Review of Fabrication Methods, Physical Properties, and Applications of Nanostructured Copper Oxides Formed via Electrochemical Oxidation. Nanomaterials 2018, 8, 379. [CrossRef] [PubMed]

60. Zhao, S.; Mugabo, Y.; Iglesias, J.; Xie, L.; Delghingaro-Augusto, V.; Lussier, R.; Peyot, M.L.; Joly, E.; Taïb, B.; Davis, M.A.; et al. $\alpha / \beta$-Hydrolase domain-6-accessible monoacylglycerol controls glucose-stimulated insulin secretion. Cell Metab. 2014, 19, 993-1007. [CrossRef] [PubMed]

61. Khalaf, N.; Ahamad, T.; Naushad, M.; Al-hokbany, N.; Al-Saeedi, S.I.; Almotairi, S.; Alshehri, S.M. Chitosan polymer complex derived nanocomposite (AgNPs/NSC) for electrochemical non-enzymatic glucose sensor. Int. J. Biol. Macromol. 2020, 146, 763-772. [CrossRef] [PubMed]

62. Kim, K.; Kim, S.; Lee, H.N.; Park, Y.M.; Bae, Y.-S.; Kim, H.-J. Electrochemically derived CuO nanorod from copper-based metal-organic framework for non-enzymatic detection of glucose. Appl. Surf. Sci. 2019, 479, 720-726. [CrossRef]

63. Lin, L.-Y.; Karakocak, B.B.; Kavadiya, S.; Soundappan, T.; Biswas, P. A highly sensitive non-enzymatic glucose sensor based on $\mathrm{Cu} / \mathrm{Cu}_{2} \mathrm{O} / \mathrm{CuO}$ ternary composite hollow spheres prepared in a furnace aerosol reactor. Sens. Actuators B Chem. 2018, 259, 745-752. [CrossRef]

64. Xu, J.; Sun, Y.; Zhang, J. Solvothermal synthesis of $\mathrm{Fe}_{3} \mathrm{O}_{4}$ nanospheres for high-performance electrochemical non-enzymatic glucose sensor. Sci. Rep. 2020, 10, 16026. [CrossRef] 
65. Zhang, J.; Sun, Y.; Li, X.; Xu, J. Fabrication of $\mathrm{NiCo}_{2} \mathrm{O}_{4}$ nanobelt by a chemical co-precipitation method for non-enzymatic glucose electrochemical sensor application. J. Alloys Compd. 2020, 831, 154796. [CrossRef]

66. Guo, S.; Zhang, C.; Yang, M.; Zhou, Y.; Bi, C.; Lv, Q.; Ma, N. A facile and sensitive electrochemical sensor for non-enzymatic glucose detection based on three-dimensional flexible polyurethane sponge decorated with nickel hydroxide. Anal. Chim. Acta 2020, 1109, 130-139. [CrossRef] [PubMed]

67. Sridara, T.; Upan, J.; Saianand, G.; Tuantranont, A.; Karuwan, C.; Jakmunee, J. Non-Enzymatic Amperometric Glucose Sensor Based on Carbon Nanodots and Copper Oxide Nanocomposites Electrode. Sensors 2020, 20, 808. [CrossRef] [PubMed]

68. Villena Gonzales, W.; Mobashsher, A.T.; Abbosh, A. The Progress of Glucose Monitoring-A Review of Invasive to Minimally and Non-Invasive Techniques, Devices and Sensors. Sensors 2019, 19, 800. [CrossRef]

69. Yu, B.; Ju, Y.; West, L.; Moussy, Y.; Moussy, F. An Investigation of Long-Term Performance of Minimally Invasive Glucose Biosensors. Diabetes Technol. Ther. 2007, 9, 265-275. [CrossRef] [PubMed]

70. Ginsberg, B.H. An Overview of Minimally Invasive Technologies. Clin. Chem. 1992, 38, 1596-1600. [CrossRef] [PubMed]

71. Dungel, P.; Long, N.; Yu, B.; Moussy, Y.; Moussy, F. Study of the effects of tissue reactions on the function of implanted glucose sensors. J. Biomed. Mater. Res. 2008, 85, 699-706. [CrossRef]

72. Park, J.; Kim, J.; Kim, S.-Y.; Cheong, W.H.; Jang, J.; Park, Y.-G.; Na, K.; Kim, Y.-T.; Heo, J.H.; Lee, C.Y.; et al. Soft, smart contact lenses with integrations of wireless circuits, glucose sensors, and displays. Sci. Adv. 2018, 4, 9841. [CrossRef] [PubMed]

73. Yao, H.; Liao, Y.; Lingley, A.R.; Afanasiev, A.; Lähdesmäki, I.; Otis, B.P.; Parviz, B.A. A contact lens with integrated telecommunication circuit and sensors for wireless and continuous tear glucose monitoring. J. Micromech. Microeng. 2012, $22,075007$. [CrossRef]

74. Liao, Y.-T.; Yao, H.; Lingley, A.; Parviz, B.; Otis, B.P. A 3- $\mu$ W CMOS Glucose Sensor for Wireless Contact-Lens Tear Glucose Monitoring. IEEE J. Solid State Circuits 2011, 47, 335-344. [CrossRef]

75. Diouf, A.; Bouchikhi, B.; El Bari, N. A nonenzymatic electrochemical glucose sensor based on molecularly imprinted polymer and its application in measuring saliva glucose. Mater. Sci. Eng. C 2019, 98, 1196-1209. [CrossRef] [PubMed]

76. Arakawa, T.; Kuroki, Y.; Nitta, H.; Chouhan, P.; Toma, K.; Sawada, S.; Takeuchi, S.; Sekita, T.; Akiyoshi, K.; Minakuchi, S.; et al. Mouthguard biosensor with telemetry system for monitoring of saliva glucose: A novel cavitas sensor. Biosens. Bioelectron. 2016, 84, 106-111. [CrossRef]

77. Du, Y.; Zhang, W.; Wang, M.L. An On-Chip Disposable Salivary Glucose Sensor for Diabetes Control. J. Diabetes Sci. Technol. 2016, 10, 1344-1352. [CrossRef]

78. Zhang, W.; Du, Y.; Wang, M.L. Noninvasive glucose monitoring using saliva nano-biosensor. Sens. Bio-Sens. Res. 2015, 4, 23-29. [CrossRef]

79. Yamaguchi, M.; Mitsumori, M.; Kano, Y. Noninvasively measuring blood glucose using saliva. IEEE Eng. Med. Biol. Mag. 1998, 17, 59-63. [CrossRef]

80. Samant, P.P.; Prausnitz, M.R. Mechanisms of sampling interstitial fluid from skin using a microneedle patch. Proc. Natl. Acad. Sci. USA 2018, 115, 4583-4588. [CrossRef]

81. Schmelzeisen-Redeker, G.; Staib, A.; Strasser, M.; Müller, U.; Schoemaker, M. Overview of a Novel Sensor for Continuous Glucose Monitoring. J. Diabetes Sci. Technol. 2013, 7, 808-814. [CrossRef]

82. Wang, P.M.; Cornwell, M.; Prausnitz, M.R. Minimally Invasive Extraction of Dermal Interstitial Fluid for Glucose Monitoring Using Microneedles. Diabetes Technol. Ther. 2005, 7, 131-141. [CrossRef] [PubMed]

83. Thennadil, S.N.; Rennert, J.L.; Wenzel, B.J.; Hazen, K.H.; Ruchti, T.L.; Block, M.B. Comparison of Glucose Concentration in Interstitial Fluid, and Capillary and Venous Blood During Rapid Changes in Blood Glucose Levels. Diabetes Technol. Ther. 2001, 3, 357-365. [CrossRef]

84. Ginsberg, B.H. The FDA Panel Advises Approval of the First Continuous Glucose Sensor. Diabetes Technol. Ther. 1999, 1, 203-204. [CrossRef] [PubMed]

85. Zhao, Y.; Zhai, Q.; Dong, D.; An, T.; Gong, S.; Shi, Q.; Cheng, W. Highly Stretchable and Strain-Insensitive Fiber-Based Wearable Electrochemical Biosensor to Monitor Glucose in the Sweat. Anal. Chem. 2019, 91, 6569-6576. [CrossRef]

86. Toi, P.T.; Trung, T.Q.; Dang, T.M.L.; Bae, C.W.; Lee, N.-E. Highly Electrocatalytic, Durable, and Stretchable Nanohybrid Fiber for On-Body Sweat Glucose Detection. ACS Appl. Mater. Interfaces 2019, 11, 10707-10717. [CrossRef]

87. Alizadeh, A.; Burns, A.; Lenigk, R.; Gettings, R.; Ashe, J.; Porter, A.; McCaul, M.; Barrett, R.; Diamond, D.; White, P.; et al. A wearable patch for continuous monitoring of sweat electrolytes during exertion. Lab Chip 2018, 18, 2632-2641. [CrossRef]

88. Lee, H.; Choi, T.K.; Lee, Y.B.; Cho, H.Y.; Ghaffari, R.; Wang, L.; Choi, H.J.; Chung, T.D.; Lu, N.; Hyeon, T.; et al. A graphene-based electrochemical device with thermoresponsive microneedles for diabetes monitoring and therapy. Nat. Nanotechnol. 2016, 11, 566-572. [CrossRef]

89. Bandodkar, A.J.; Wang, J. Non-invasive wearable electrochemical sensors: A review. Trends Biotechnol. 2014, 32, 363-371. [CrossRef] [PubMed]

90. Chen, J.; Zhang, W.-D.; Ye, J.-S. Nonenzymatic electrochemical glucose sensor based on $\mathrm{MnO}_{2} / \mathrm{MWNT}$ nanocomposite. Electrochem. Commun. 2008, 10, 1268-1271. [CrossRef]

91. Wang, J. Electrochemical Glucose Biosensors. Chem. Rev. 2007, 108, 814-825. [CrossRef] [PubMed]

92. Gernet, S.; Koudelka, M.; De Rooij, N.F. Fabrication and characterization of a planar electrochemical cell and its application as a glucose sensor. Sens. Actuators 1989, 18, 59-70. [CrossRef] 
93. El-Ads, E.H.; Galal, A.; Atta, N.F. Electrochemistry of glucose at gold nanoparticles modified graphite $/ \mathrm{SrPdO}_{3}$ electrode-Towards a novel non-enzymatic glucose sensor. J. Electroanal. Chem. 2015, 749, 42-52. [CrossRef]

94. Zanello, P.; Nervi, C.; De Biani, F.F. Inorganic Electrochemistry: Theory, Practice and Application; Royal Society of Chemistry: London, UK, 2019.

95. Bard, A.J.; Faulkner, L.R. Electrochemical Methods Fundamentals and Applications; John Wiley and Sons, Inc.: Hoboken, NJ, USA, 2001.

96. Liu, S.; Zeng, W.; Guo, Q.; Li, Y. Metal oxide-based composite for non-enzymatic glucose sensors. J. Mater. Sci. Mater. Electron. 2020, 31, 16111-16136. [CrossRef]

97. Zhu, H.; Li, L.; Zhou, W.; Shao, Z.; Chen, X. Advances in non-enzymatic glucose sensors based on metal oxides. J. Mater. Chem. B 2016, 4, 7333-7349. [CrossRef]

98. Toghill, K.E.; Compton, R.G. Electrochemical Non-enzymatic Glucose Sensors: A Perspective and an Evaluation. Int. J. Electrochem. Sci. 2010, 5, 1246-1301.

99. Wei, M.; Qiao, Y.; Zhao, H.; Liang, J.; Li, T.; Luo, Y.; Lu, S.; Shi, X.; Lu, W.; Sun, X. Electrochemical non-enzymatic glucose sensors: Recent progress and perspectives. Chem. Commun. 2020, 56, 14553. [CrossRef]

100. Suzuki, N.; Lee, J.; Loew, N.; Takahashi-Inose, Y.; Okuda-Shimazaki, J.; Kojima, K.; Mori, K.; Tsugawa, W.; Sode, K. Engineered Glucose Oxidase Capable of Quasi-Direct Electron Transfer after a Quick-and-Easy Modification with a Mediator. Int. J. Mol. Sci. 2020, 21, 1137. [CrossRef]

101. Lee, I.; Loew, N.; Tsugawa, W.; Lin, C.-E.; Probst, D.; La Belle, J.T.; Sode, K. The electrochemical behavior of a FAD dependent glucose dehydrogenase with direct electron transfer subunit by immobilization on self-assembled monolayers. Bioelectrochemistry 2018, 121, 1-6. [CrossRef] [PubMed]

102. Pletcher, D. Electrocatalysis: Present and future. J. Appl. Electrochem. 1984, 14, 403-415. [CrossRef]

103. Burke, L.D. Premonolayer oxidation and its role in electrocatalysis. Electrochim. Acta 1994, 39, 1841. [CrossRef]

104. Wang, J. Amperometric biosensors for clinical and therapeutic drug monitoring: A review. J. Pharm. Biomed. Anal. 1999, 19, 47-53. [CrossRef]

105. Ernst, S.; Heitbaum, J.; Hamann, C.H. The electrooxidation of glucose in phosphate buffer solutions: Part I. Reactivity and kinetics below $350 \mathrm{mV} /$ RHE. J. Electroanal. Chem. 1979, 100, 173-183. [CrossRef]

106. Luo, P.; Zhang, F.; Baldwin, R.P. Comparison of metallic electrodes for constant-potential amperometric detection of carbohydrates, amino acids and related compounds in flow systems. Anal. Chim. Acta 1991, 244, 169-178. [CrossRef]

107. Mello, G.A.B.; Cheuquepán, W.; Briega-Martos, V.; Feliu, J.M. Glucose electro-oxidation on Pt(100) in phosphate buffer solution (pH 7): A mechanistic study. Electrochim. Acta 2020, 354, 136765. [CrossRef]

108. Li, Y.; Song, Y.-Y.; Yang, C.; Xia, X.-H. Hydrogen bubble dynamic template synthesis of porous gold for nonenzymatic electrochemical detection of glucose. Electrochem. Commun. 2007, 9, 981-988. [CrossRef]

109. Sun, Y.; Buck, H.; Mallouk, T.E. Combinatorial Discovery of Alloy Electrocatalysts for Amperometric Glucose Sensors. Anal. Chem. 2001, 73, 1599-1604. [CrossRef]

110. Wang, T.; Yu, Y.; Tian, H.; Hu, J. A Novel Non-Enzymatic Glucose Sensor Based on Cobalt Nanoparticles Implantation-Modified Indium Tin Oxide Electrode. Electroanalysis 2014, 26, 2693-2700. [CrossRef]

111. Chang, G.; Shu, H.; Huang, Q.; Oyama, M.; Ji, K.; Liu, X.; He, Y. Synthesis of highly dispersed Pt nanoclusters anchored graphene composites and their application for non-enzymatic glucose sensing. Electrochim. Acta 2015, 157, 149-157. [CrossRef]

112. Wu, G.-H.; Song, X.-H.; Wu, Y.-F.; Chen, X.-M.; Luo, F.; Chen, X. Non-enzymatic electrochemical glucose sensor based on platinum nanoflowers supported on graphene oxide. Talanta 2013, 105, 379-385. [CrossRef]

113. Geng, D.; Bo, X.; Guo, L. Ni-doped molybdenum disulfide nanoparticles anchored on reduced graphene oxide as novel electroactive material for a non-enzymatic glucose sensor. Sens. Actuators B Chem. 2017, 244, 131-141. [CrossRef]

114. Karikalan, N.; Karthik, R.; Chen, S.-M.; Karuppiah, C.; Elangovan, A. Sonochemical Synthesis of Sulfur Doped Reduced Graphene Oxide Supported CuS Nanoparticles for the Non-Enzymatic Glucose Sensor Applications. Sci. Rep. 2017, 7, 2494. [CrossRef] [PubMed]

115. Zheng, W.; Li, Y.; Hu, L.; Lee, L.Y.S. Use of carbon supports with copper ion as a highly sensitive non-enzymatic glucose sensor. Sens. Actuators B Chem. 2019, 282, 187-196. [CrossRef]

116. Kangkamano, T.; Numnuam, A.; Limbut, W.; Kanatharana, P.; Thavarungkul, P. Chitosan cryogel with embedded gold nanoparticles decorated multiwalled carbon nanotubes modified electrode for highly sensitive flow based non-enzymatic glucose sensor. Sens. Actuators B Chem. 2017, 246, 854-863. [CrossRef]

117. Rathod, D.; Dickinson, C.; Egan, D.; Dempsey, E. Platinum nanoparticle decoration of carbon materials with applications in non-enzymatic glucose sensing. Sens. Actuators B Chem. 2010, 143, 547-554. [CrossRef]

118. Chen, X.-M.; Cai, Z.-M.; Lin, Z.-J.; Jia, T.-T.; Liu, H.-Z.; Jiang, Y.-Q.; Chen, X. A novel non-enzymatic ECL sensor for glucose using palladium nanoparticles supported on functional carbon nanotubes. Biosens. Bioelectron. 2009, 24, 3475-3480. [CrossRef]

119. Kailasa, S.; Geeta, B.; Jayarambabu, N.; Reddy, R.K.K.; Sharma, S.; Rao, K.V. Conductive Polyaniline Nanosheets (CPANINS) for a non-enzymatic glucose sensor. Mat. Lett. 2019, 245, 118-121. [CrossRef]

120. Esmaeeli, A.; Ghaffarinejad, A.; Zahedi, A.; Vahidi, O. Copper oxide-polyaniline nanofiber modified fluorine doped tin oxide (FTO) electrode as non-enzymatic glucose sensor. Sens. Actuators B Chem. 2018, 266, 294-301. [CrossRef]

121. Emir, G.; Dilgin, Y.; Ramanaviciene, A.; Ramanavicius, A. Amperometric nonenzymatic glucose biosensor based on graphite rod electrode modified by Ni-nanoparticle/polypyrrole composite. Microchem. J. 2021, 161, 105751. [CrossRef] 
122. Quintero-Jaime, A.F.; Conzuelo, F.; Schuhmann, W.; Cazorla-Amorós, D.; Morallón, E. Multi-wall carbon nanotubes electrochemically modified with phosphorus and nitrogen functionalities as a basis for bioelectrodes with improved performance. Electrochim. Acta 2021, 387, 138530. [CrossRef]

123. Wang, Y.; Chen, J.; Zhou, C.; Zhou, L.; Kong, Y.; Long, H.; Zhong, S. A novel self-cleaning, non-enzymatic glucose sensor working under a very low applied potential based on a Pt nanoparticle-decorated $\mathrm{TiO}_{2}$ nanotube array electrode. Electrochim. Acta 2014, 115, 269-276. [CrossRef]

124. Lee, K.K.; Loh, P.Y.; Sow, C.H.; Chin, W.S. CoOOH nanosheets on cobalt substrate as a non-enzymatic glucose sensor. Electrochem. Commun. 2012, 20, 128-132. [CrossRef]

125. Zhang, Y.; Li, N.; Xiang, Y.; Wang, D.; Zhang, P.; Wang, Y.; Lu, S.; Xu, R.; Zhao, J. A flexible non-enzymatic glucose sensor based on copper nanoparticles anchored on laser-induced graphene. Carbon 2020, 156, 506-513. [CrossRef]

126. Zhang, L.; Ye, C.; Li, X.; Ding, Y.; Liang, H.; Zhao, G.; Wang, Y. A CuNi/C Nanosheet Array Based on a Metal-Organic Framework Derivate as a Supersensitive Non-Enzymatic Glucose Sensor. Nano Micro Lett. 2018, 10, 28. [CrossRef] [PubMed]

127. Marini, S.; Mansour, N.B.; Hjiri, M.; Dhahri, R.; El Mir, L.; Espro, C.; Bonavita, A.; Galvagno, S.; Neri, G.; Leonardi, S.G. Non-enzymatic Glucose Sensor Based on Nickel/Carbon Composite. Electroanalysis 2018, 30, 727-733. [CrossRef]

128. Shabnam, L.; Faisal, S.N.; Roy, A.K.; Haque, E.; Minett, A.I.; Gomes, V.G. Doped graphene/Cu nanocomposite: A high sensitivity non-enzymatic glucose sensor for food. Food Chem. 2017, 221, 751-759. [CrossRef]

129. Ramachandran, K.; Rajkumar, T.; Babu, K.J.; Kumar, G.G. Ni-Co bimetal nanowires filled multiwalled carbon nanotubes for the highly sensitive and selective non-enzymatic glucose sensor applications. Sci. Rep. 2016, 6, 36583. [CrossRef]

130. Shen, C.; Su, J.; Li, X.; Luo, J.; Yang, M. Electrochemical sensing platform based on Pd-Au bimetallic cluster for non-enzymatic detection of glucose. Sens. Actuators B Chem. 2015, 209, 695-700. [CrossRef]

131. Hoa, L.T.; Sun, K.G.; Hur, S.H. Highly sensitive non-enzymatic glucose sensor based on Pt nanoparticle decorated graphene oxide hydrogel. Sens. Actuators B Chem. 2015, 210, 618-623. [CrossRef]

132. Sun, A.; Zheng, J.; Sheng, Q. A highly sensitive non-enzymatic glucose sensor based on nickel and multi-walled carbon nanotubes nanohybrid films fabricated by one-step co-electrodeposition in ionic liquids. Electrochim. Acta 2012, 65, 64-69. [CrossRef]

133. Ren, Z.; Mao, H.; Luo, H.; Deng, X.; Liu, Y. One-step formation of a hybrid material of graphene and porous Ni with highly active $\mathrm{Ni}(\mathrm{OH})_{2}$ used for glucose detection. Nanotechnology 2020, 31, 185501. [CrossRef]

134. Heyser, C.; Schrebler, R.; Grez, P. New route for the synthesis of nickel (II) oxide nanostructures and its application as nonenzymatic glucose sensor. J. Electroanal. Chem. 2019, 832, 189-195. [CrossRef]

135. Ahmad, R.; Tripathy, N.; Ahn, M.-S.; Bhat, K.S.; Mahmoudi, T.; Wang, Y.; Yoo, J.-Y.; Kwon, D.-W.; Yang, W.-Y.; Hahn, Y.-B. Highly Efficient Non-Enzymatic Glucose Sensor Based on CuO Modified Vertically-Grown ZnO Nanorods on Electrode. Sci. Rep. 2017, 7, 5715. [CrossRef]

136. Chung, R.-J.; Wang, A.-N.; Liao, Q.-L.; Chuang, K.-Y. Non-Enzymatic Glucose Sensor Composed of Carbon-Coated Nano-Zinc Oxide. Nanomaterials 2017, 7,36. [CrossRef]

137. Mani, S.; Vediyappan, V.; Chen, S.-M.; Madhu, R.; Pitchaimani, V.; Chang, J.Y.; Liu, S.-B. Hydrothermal synthesis of NiWO 4 crystals for high performance non-enzymatic glucose biosensors. Sci. Rep. 2016, 6, 24128. [CrossRef] [PubMed]

138. Ghanbari, K.H.; Babaei, Z. Fabrication and characterization of non-enzymatic glucose sensor based on ternary NiO/CuO/polyaniline nanocomposite. Anal. Biochem. 2016, 498, 37-46. [CrossRef]

139. Zhang, Y.; Su, L.; Manuzzi, D.; de los Monteros, H.V.E.; Jia, W.; Huo, D.; Hou, C.; Lei, Y. Ultrasensitive and selective non-enzymatic glucose detection using copper nanowires. Biosens. Bioelectron. 2012, 31, 426-432. [CrossRef] [PubMed]

140. Liu, Y.; Zhao, W.; Li, X.; Liu, J.; Han, Y.; Wu, J.; Zhang, X.; Xu, Y. Hierarchical $\alpha-\mathrm{Fe}_{2} \mathrm{O}_{3}$ microcubes supported on Ni foam as non-enzymatic glucose sensor. Appl. Surf. Sci. 2020, 512, 145710. [CrossRef]

141. Liu, X.; Yang, W.; Chen, L.; Jia, J. Three-Dimensional Copper Foam Supported CuO Nanowire Arrays: An Efficient Non-enzymatic Glucose Sensor. Electrochim. Acta 2017, 235, 219-526. [CrossRef]

142. Ranjani, M.; Sathishkumar, Y.; Lee, Y.S.; Yoo, D.J.; Kim, A.R.; Kumar, G.G. Ni-Co alloy nanostructures anchored on mesoporous silica nanoparticles for non-enzymatic glucose sensor applications. RSC Adv. 2015, 5, 57804-57814. [CrossRef]

143. Ensafi, A.A.; Abarghoui, M.M.; Rezaei, B. A new non-enzymatic glucose sensor based on copper/porous silicon nanocomposite. Electrochim. Acta 2014, 123, 219-226. [CrossRef]

144. Huo, H.; Guo, C.; Li, G.; Han, X.; Xu, C. Reticular-vein-like $\mathrm{Cu} @ \mathrm{Cu}_{2} \mathrm{O} /$ reduced graphene oxide nanocomposites for a nonenzymatic glucose sensor. RSC Adv. 2014, 4, 20459-20465. [CrossRef]

145. Mello, G.A.B.; Cheuquepán, W.; Feliu, J.M. Investigation of reactivity of Pt basal planes towards glucose electro-oxidation in neutral solution ( $\mathrm{pH}$ 7): Structure-sensitivity dependence and mechanistic study. J. Electroanal. Chem. 2020, 878, 114549. [CrossRef]

146. Housmans, T.H.M.; Wonders, A.H.; Koper, M.T.M. Structure sensitivity of methanol electrooxidation pathways on platinum: An on-line electrochemical mass spectrometry study. J. Phys. Chem. B 2006, 110, 10021-10031. [CrossRef]

147. Solla-Gullon, J.; Vidal-Iglesias, F.J.; Lopez-Cudero, A.; Garnier, E.; Feliu, J.M.; Aldaza, A. Shape-dependent electrocatalysis: Methanol and formic acid electrooxidation on preferentially oriented Pt nanoparticles. Phys. Chem. Chem. Phys. 2008, 10, 3689-3698. [CrossRef]

148. Ren, J.; Shi, W.T.; Li, K.; Ma, Z.F. Ultrasensitive platinum nanocubes enhanced amperometric glucose biosensor based on chitosan and nafion film. Sens. Actuators B Chem. 2012, 163, 115-120. [CrossRef] 
149. Khan, Z.; Singh, T.; Hussain, J.I.; Hashmi, A.A. Au (III)-CTAB reduction by ascorbic acid: Preparation and characterization of gold nanoparticles. Colloids Surf. B Biointerfaces 2013, 104, 11-17. [CrossRef] [PubMed]

150. Cheng, W.; Dong, S.; Wang, E. Synthesis and Self-Assembly of Cetyltrimethylammonium Bromide-Capped Gold Nanoparticles. Langmuir 2003, 19, 9434-9439. [CrossRef]

151. Liu, Y.; Zhang, Y.; Chen, J.; Pang, H. Copper metal-organic framework nanocrystal for plane effect nonenzymatic electro-catalytic activity of glucose. Nanoscale 2014, 6, 10989-10994. [CrossRef] [PubMed]

152. Ye, J.-S.; Hsu, S.-Y.; Lee, C.-L. Sequential and Transient Electrocatalysis of Glucose Oxidation Reactions by Octahedral, Rhombic Dodecahedral, and Cubic Palladium Nanocrystals. Electrochim. Acta 2016, 211, 1024-1032. [CrossRef]

153. Liang, Z.X.; Zhao, T.S.; Xu, J.B.; Zhu, L.D. Mechanism study of the ethanol oxidation reaction on palladium in alkaline media. Electrochim. Acta 2009, 54, 2203-2208. [CrossRef]

154. Hoshi, N.; Nakamura, M.; Maki, N.; Yamaguchi, S.; Kitajima, A. Structural effects on voltammograms of the low index planes of palladium and $\mathrm{Pd}(\mathrm{S})-[\mathrm{n}(100) \times(111)]$ surfaces in alkaline solution. J. Electroanal. Chem. 2008, 624, 134-138. [CrossRef]

155. Shao, M.H.; Odell, J.; Humbert, M.; Yu, T.Y.; Xia, Y.N. Electrocatalysis on shape-controlled palladium nanocrystals: Oxygen reduction reaction and formic acid oxidation. J. Phys. Chem. C 2013, 117, 4172-4180. [CrossRef]

156. Li, Z.; Qian, W.; Guo, H.; Song, X.; Yan, H.; Jin, R.; Zheng, J. Facile preparation of novel Pd nanowire networks on a polyaniline hydrogel for sensitive determination of glucose. Anal. Bioanal. Chem. 2020, 412, 6849-6858. [CrossRef]

157. Niu, X.; Lan, M.; Chen, C.; Zhao, H. Nonenzymatic electrochemical glucose sensor based on novel Pt-Pd nanoflakes. Talanta 2012, 99, 1062-1067. [CrossRef]

158. Meng, L.; Jin, J.; Yang, G.X.; Lu, T.H.; Zhang, H.; Cai, C.X. Nonenzymatic electrochemical detection of glucose based on palladium-single-walled carbon nanotube hybrid nanostructures. Anal. Chem. 2009, 81, 7271-7280. [CrossRef]

159. Kuang, Y.J.; Wu, B.H.; Hu, D.; Zhang, X.H.; Chen, J.H. One-pot synthesis of highly dispersed palladium nanoparticles on acetylenic ionic liquid polymer functionalized carbon nanotubes for electrocatalytic oxidation of glucose. J. Solid State Electrochem. 2012, 16, 759-766. [CrossRef]

160. Lu, L.M.; Li, H.B.; Qu, F.L.; Zhang, X.B.; Shen, G.L.; Yu, R.Q. In situ synthesis of palladium nanoparticle-graphene nanohybrids and their application in nonenzymatic glucose biosensors. Biosens. Bioelectron. 2011, 26, 3500-3504. [CrossRef]

161. Becerik, I.; Kadirgan, F. The electrocatalytic properties of palladium electrodes for the oxidation of d-glucose in alkaline medium. Electrochim. Acta 1992, 37, 2651-2657. [CrossRef]

162. Prehn, R.; Cortina-Puig, M.; Muñoz, F.X. A Non-Enzymatic Glucose Sensor Based on the Use of Gold Micropillar Array Electrodes. J. Electrochem. Soc. 2012, 159, F134-F139. [CrossRef]

163. Xiang, X.; Feng, S.; Chen, J.; Feng, J.; Hou, Y.; Ruan, Y.; Weng, X.; Milcovich, G. Gold nanoparticles/electrochemically expanded graphite composite: A bifunctional platform toward glucose sensing and SERS applications. J. Electroanal. Chem. 2019, 851, 113471. [CrossRef]

164. Zhu, Y.; Zhang, X.; Sun, J.; Li, M.; Lin, Y.; Kang, K.; Meng, Y.; Feng, Z.; Wang, J. A non-enzymatic amperometric glucose sensor based on the use of graphene frameworks-promoted ultrafine platinum nanoparticles. Microchim. Acta 2019, 186, 538. [CrossRef]

165. Zhang, L.; Wang, N.; Cao, P.; Lin, M.; Xu, L.; Ma, H. Electrochemical non-enzymatic glucose sensor using ionic liquid incorporated cobalt-based metal-organic framework. Microchem. J. 2020, 159, 105343. [CrossRef]

166. Tomanin, P.P.; Cherepanov, P.V.; Besford, Q.A.; Christofferson, A.J.; Amodio, A.; McConville, C.F.; Yarovsky, I.; Caruso, F.; Cavalieri, F. Cobalt Phosphate Nanostructures for Non-Enzymatic Glucose Sensing at Physiological pH. ACS Appl. Mater. Interfaces 2018, 10, 42786-42795. [CrossRef]

167. Sun, Y.; Li, Y.; Wang, N.; Xu, Q.Q.; Xu, L.; Lin, M. Copper-based Metal-organic Framework for Non-enzymatic Electrochemical Detection of Glucose. Electroanalysis 2018, 30, 474-478. [CrossRef]

168. Wang, B.; Wu, Y.; Chen, Y.; Weng, B.; Li, C. Flexible paper sensor fabricated via in situ growth of Cu nanoflower on RGO sheets towards amperometrically non-enzymatic detection of glucose. Sens. Actuators B Chem. 2017, 238, 802-808. [CrossRef]

169. Kung, C.-W.; Cheng, Y.-H.; Ho, K.-C. Single layer of nickel hydroxide nanoparticles covered on a porous Ni foam and its application for highly sensitive non-enzymatic glucose sensor. Sens. Actuators B Chem. 2014, 204, 159-166. [CrossRef]

170. Lu, L.-M.; Zhang, L.; Qu, F.-L.; Lu, H.-X.; Zhang, X.-B.; Wu, Z.-S.; Huan, S.-Y.; Wang, Q.-A.; Shen, G.-L.; Yu, R.-Q. A nano-Ni based ultrasensitive nonenzymatic electrochemical sensor for glucose: Enhancing sensitivity through a nanowire array strategy. Biosens. Bioelectron. 2009, 25, 218-223. [CrossRef]

171. Samoson, K.; Thavarungkul, P.; Kanatharana, P.; Limbut, W. A Nonenzymatic Glucose Sensor Based on the Excellent Dispersion of a Graphene Oxide-Poly (acrylic acid)-Palladium Nanoparticle-Modified Screen-Printed Carbon Electrode. J. Electrochem. Soc. 2019, 166, B1079. [CrossRef]

172. Rafatmah, E.; Hemmateenejad, B. Dendrite gold nanostructures electrodeposited on paper fibers: Application to electrochemical non-enzymatic determination of glucose. Sens. Actuators B Chem. 2020, 304, 127335. [CrossRef]

173. Jeong, H.; Nguyen, D.M.; Lee, M.S.; Kim, H.G.; Ko, S.C.; Kwac, L.K. N-doped graphene-carbon nanotube hybrid networks attaching with gold nanoparticles for glucose non-enzymatic sensor. Mater. Sci. Eng. C 2018, 90, 38-45. [CrossRef]

174. Nugraha, A.S.; Li, C.; Bo, J.; Iqbal, M.; Alshehri, S.M.; Ahamad, T.; Malgras, V.; Yamauchi, Y.; Asahi, T. Block-Copolymer-Assisted Electrochemical Synthesis of Mesoporous Gold Electrodes: Towards a Non-Enzymatic Glucose Sensor. ChemElectroChem 2017, 4 2571-2576. [CrossRef] 
175. Soomro, R.A.; Akyuz, O.P.; Ozturk, R.; Ibupoto, Z.H. Highly sensitive non-enzymatic glucose sensing using gold nanocages as efficient electrode material. Sens. Actuators B Chem. 2016, 233, 230-236. [CrossRef]

176. Heli, H.; Amirizadeh, O. Non-enzymatic glucose biosensor based on hyperbranched pine-like gold nanostructure. Mater. Sci. Eng. C 2016, 63, 150-154. [CrossRef] [PubMed]

177. Chang, G.; Shu, H.; Ji, K.; Oyama, M.; Liu, X.; He, Y. Gold nanoparticles directly modified glassy carbon electrode for nonenzymatic detection of glucose. Appl. Surf. Sci. 2014, 288, 524-529. [CrossRef]

178. Ismail, N.S.; Le, Q.H.; Yoshikawa, H.; Saito, M.; Tamiya, E. Development of Non-enzymatic Electrochemical Glucose Sensor Based on Graphene Oxide Nanoribbon-Gold Nanoparticle Hybrid. Electrochim. Acta 2014, 146, 98-105. [CrossRef]

179. Gougis, M.; Tabet-Aoul, A.; Ma, D.; Mohamedi, M. Laser synthesis and tailor-design of nanosized gold onto carbon nanotubes for non-enzymatic electrochemical glucose sensor. Sens. Actuators B Chem. 2014, 193, 363-369. [CrossRef]

180. Lamiri, L.; Belgherbi, O.; Dehchar, C.; Laidoudi, S.; Tounsi, A.; Nessark, B.; Habelhames, F.; Hamam, A.; Gourari, B. Performance of polybithiophene-palladium particles modified electrode for non-enzymatic glucose detection. Synth. Met. 2020, $266,116437$. [CrossRef]

181. Promsuwan, K.; Kachatong, N.; Limbut, W. Simple flow injection system for non-enzymatic glucose sensing based on an electrode modified with palladium nanoparticles-graphene nanoplatelets/mullti-walled carbon nanotubes. Electrochim. Acta 2019, 320, 134621. [CrossRef]

182. Wang, F.; Niu, X.; Wang, W.; Jing, W.; Huang, Y.; Zhang, J. Green synthesis of Pd nanoparticles via extracted polysaccharide applied to glucose detection. J. Taiwan Inst. Chem. Eng. 2018, 93, 87-93. [CrossRef]

183. Wu, Q.; Sheng, Q.; Zheng, J. Nonenzymatic sensing of glucose using a glassy carbon electrode modified with halloysite nanotubes heavily loaded with palladium nanoparticles. J. Electroanal. Chem. 2016, 762, 51-58. [CrossRef]

184. Wang, Q.; Wang, Q.; Qi, K.; Xue, T.; Liu, C.; Zheng, W.; Cui, X. In situ preparation of porous Pd nanotubes on a GCE for non-enzymatic electrochemical glucose sensors. Anal. Methods 2015, 7, 8605-8610. [CrossRef]

185. Haghighi, B.; Karimi, B.; Tavahodi, M.; Behzadneia, H. Fabrication of a nonenzymatic glucose sensor using Pd-nanoparticles decorated ionic liquid derived fibrillated mesoporous carbon. Mater. Sci. Eng. C 2015, 52, 219-224. [CrossRef] [PubMed]

186. Singh, B.; Bhardwaj, N.; Jain, V.K.; Bhatia, V. Palladium nanoparticles decorated electrostatically functionalized MWCNTs as a non enzymatic glucose sensor. Sens. Actuator A Phys. 2014, 220, 126-133. [CrossRef]

187. Cai, Z.-X.; Liu, C.-C.; Wu, G.-H.; Chen, X.-M.; Chen, X. Palladium nanoparticles deposit on multi-walled carbon nanotubes and their catalytic applications for electrooxidation of ethanol and glucose. Electrochim. Acta 2013, 112, 756-762. [CrossRef]

188. Wei, Y.H.; Hsieh, C.K.; Tseng, F.G. Highly-Sensitive Non-Enzymatic Glucose Sensor via Nano Platinum Crystals Fabricated by Phase-Controlled Electrochemical Deposition. J. Electrochem. Soc. 2018, 165, B48. [CrossRef]

189. Malhotra, S.; Tang, Y.; Varshney, P.K. Non-Enzymatic Glucose Sensor based on Electrodeposition of Platinum Particles on Polyaniline Modified Pt Electrode. Anal. Bioanal. Electrochem. 2018, 10, 699-715.

190. Weremfo, A.; Fong, S.T.C.; Khan, A.; Hibbert, D.B.; Zhao, C. Electrochemically roughened nanoporous platinum electrodes for non-enzymatic glucose sensors. Electrochim. Acta 2017, 231, 20-26. [CrossRef]

191. Zhou, X.; Zheng, X.; Lv, R.; Kong, D.; Li, Q.L. Electrodeposition of platinum on poly (glutamic acid) modified glassy carbon electrode for non-enzymatic amperometric glucose detection. Electrochim. Acta 2013, 107, 164-169. [CrossRef]

192. Chang, H.-W.; Tsai, Y.-C.; Cheng, C.-W.; Lin, C.-Y.; Wu, P.-H. Preparation of platinum/carbon nanotube in aqueous solution by femtosecond laser for non-enzymatic glucose determination. Sens. Actuators B Chem. 2013, 183, 34-39. [CrossRef]

193. Guo, M.Q.; Hong, H.S.; Tang, X.N.; Fang, H.D.; Xu, X.H. Ultrasonic electrodeposition of platinum nanoflowers and their application in nonenzymatic glucose sensors. Electrochim. Acta 2012, 63, 1-8. [CrossRef]

194. Sun, Q.; Ding, J.; Chen, D.; Han, C.; Jiang, M.; Li, T.-T.; Hu, Y.; Qian, J.; Huang, S. Silica-Templated Metal Organic FrameworkDerived Hierarchically Porous Cobalt Oxide in Nitrogen-Doped Carbon Nanomaterials for Electrochemical Glucose Sensing. ChemElectroChem 2021, 8, 812-818. [CrossRef]

195. Wang, X.; Wang, M.; Feng, S.; He, D.; Jiang, P. Controlled synthesis of flower-like cobalt phosphate microsheet arrays supported on $\mathrm{Ni}$ foam as a highly efficient 3D integrated anode for non-enzymatic glucose sensing. Inorg. Chem. Front. 2020, 7, 108-116. [CrossRef]

196. Chaiyo, S.; Mehmeti, E.; Siangproh, W.; Hoang, T.L.; Nguyen, H.P.; Chailapakul, O.; Kalcher, K. Non-enzymatic electrochemical detection of glucose with a disposable paper-based sensor using a cobalt phthalocyanine-ionic liquid-graphene composite. Biosens. Bioelectron. 2018, 102, 113-120. [CrossRef]

197. Xie, F.; Cao, X.; Qu, F.; Asiri, A.M.; Sun, X. Cobalt nitride nanowire array as an efficient electrochemical sensor for glucose and $\mathrm{H}_{2} \mathrm{O}_{2}$ detection. Sens. Actuators B Chem. 2018, 255, 1254-1261. [CrossRef]

198. Liu, T.; Li, M.; Guo, L. Designing and facilely synthesizing a series of cobalt nitride $\left(\mathrm{Co}_{4} \mathrm{~N}\right)$ nanocatalysts as non-enzymatic glucose sensors: A comparative study toward the influences of material structures on electrocatalytic activities. Talanta 2018, 181, 154-164. [CrossRef]

199. Liu, Y.; Cao, X.; Kong, R.; Du, G.; Asiri, A.M.; Lu, Q.; Sun, X. Cobalt phosphide nanowire array as an effective electrocatalyst for non-enzymatic glucose sensing. J. Mater. Chem. B 2017, 5, 1901-1904. [CrossRef] [PubMed]

200. Premlatha, S.; Sivasakthi, P.; Bapu, G.N.K.R. Electrodeposition of a 3D hierarchical porous flower-like cobalt-MWCNT nanocomposite electrode for non-enzymatic glucose sensing. RSC Adv. 2015, 5, 74374-74380. [CrossRef] 
201. Ci, S.; Wen, Z.; Mao, S.; Hou, Y.; Cui, S.; He, Z.; Chen, J. One-pot synthesis of high-performance Co/graphene electrocatalysts for glucose fuel cells free of enzymes and precious metals. Chem. Commun. 2015, 51, 9354-9357. [CrossRef] [PubMed]

202. Hou, L.; Zhao, H.; Bi, S.; Xu, Y.; Lu, Y. Ultrasensitive and highly selective sandpaper-supported copper framework for nonenzymatic glucose sensor. Electrochim. Acta 2017, 248, 281-291. [CrossRef]

203. Ju, L.; Wu, G.; Lu, B.; Li, X.; Wu, H.; Liu, A. Non-enzymatic Amperometric Glucose Sensor Based on Copper Nanowires Decorated Reduced Graphene Oxide. Electroanalysis 2016, 28, 2543-2551. [CrossRef]

204. Jiang, D.; Liu, Q.; Wang, K.; Qian, J.; Dong, X.; Yang, X.; Du, X.; Qiu, B. Enhanced non-enzymatic glucose sensing based on copper nanoparticles decorated nitrogen-doped graphene. Biosens. Bioelectron. 2014, 54, 273-278. [CrossRef]

205. Huang, J.; Dong, Z.; Li, Y.; Li, J.; Wang, J.; Yang, H.; Li, S.; Guo, S.; Jin, J.; Li, R. High performance non-enzymatic glucose biosensor based on copper nanowires-carbon nanotubes hybrid for intracellular glucose study. Sens. Actuators B Chem. 2013, 182, 618-624. [CrossRef]

206. Luo, J.; Zhang, H.; Jiang, S.; Jiang, J.; Liu, X. Facile one-step electrochemical fabrication of a non-enzymatic glucose-selective glassy carbon electrode modified with copper nanoparticles and graphene. Microchim. Acta 2012, 177, 485-490. [CrossRef]

207. Wu, H.; Yu, Y.; Gao, W.; Gao, A.; Qasim, A.M.; Zhang, F.; Wang, J.; Ding, K.; Wu, G.; Chu, P.K. Nickel plasma modification of graphene for high-performance non-enzymatic glucose sensing. Sens. Actuators B Chem. 2017, 251, 842-850. [CrossRef]

208. Kim, S.; Lee, S.H.; Cho, M.; Lee, Y. Solvent-assisted morphology confinement of a nickel sulfide nanostructure and its application for non-enzymatic glucose sensor. Biosens. Bioelectron. 2016, 85, 587-595. [CrossRef]

209. Kannan, P.K.; Rout, C.S. High Performance Non-enzymatic Glucose Sensor Based on One-Step Electrodeposited Nickel Sulfide. Chem. Eur. J. 2015, 21, 9355-9359. [CrossRef]

210. Choi, T.; Kim, S.H.; Lee, C.W.; Kim, H.; Choi, S.-K.; Kim, S.-H.; Kim, E.; Park, J.; Kin, H. Synthesis of carbon nanotube-nickel nanocomposites using atomic layer deposition for high-performance non-enzymatic glucose sensing. Biosens. Bioelectron. 2015, 63, 325-330. [CrossRef]

211. Huo, H.; Zhao, Y.; $\mathrm{Xu}, \mathrm{C} .3 \mathrm{D} \mathrm{Ni} \mathrm{S}_{2}$ nanosheet arrays supported on $\mathrm{Ni}$ foam for high-performance supercapacitor and nonenzymatic glucose detection. J. Mater. Chem. A 2014, 2, 15111-15117. [CrossRef]

212. Lin, T.-W.; Liu, C.-J.; Dai, C.-S. $\mathrm{Ni}_{3} \mathrm{~S}_{2}$ / carbon nanotube nanocomposite as electrode material for hydrogen evolution reaction in alkaline electrolyte and enzyme-free glucose detection. Appl. Catal. B 2014, 154-155, 213-220. [CrossRef]

213. Niu, X.; Lan, M.; Zhao, H.; Chen, C. Highly Sensitive and Selective Nonenzymatic Detection of Glucose Using Three-Dimensional Porous Nickel Nanostructures. Anal. Chem. 2013, 85, 3561-3569. [CrossRef]

214. Nie, H.G.; Yao, Z.; Zhou, X.M.; Yang, Z.; Huang, S.M. Nonenzymatic electrochemical detection of glucose using well-distributed nickel nanoparticles on straight multi-walled carbon nanotubes. Biosens. Bioelectron. 2011, 30, 28-34. [CrossRef] [PubMed]

215. Si, P.; Huang, Y.; Wang, T.; Ma, J. Nanomaterials for electrochemical non-enzymatic glucose biosensors. RSC Adv. 2013, 3, 3487-3502. [CrossRef]

216. Song, Y.Y.; Zhang, D.; Gao, W.; Xia, X.-H. Nonenzymatic Glucose Detection by Using a Three-Dimensionally Ordered, Macroporous Platinum Template. Chem. Eur. J. 2005, 11, 2177-2182. [CrossRef]

217. Chawla, M.; Pramanick, B.; Randhawa, J.K.; Siril, P.F. Effect of composition and calcination on the enzymeless glucose detection of Cu-Ag bimetallic nanocomposites. Mater. Today Commun. 2020, 26, 101815. [CrossRef]

218. Nodehi, Z.; Rafati, A.A.; Ghaffarinejad, A. Palladium-silver polyaniline composite as an efficient catalyst for ethanol oxidation. Appl. Catal. A Gen. 2018, 554, 24-34. [CrossRef]

219. Ma, D.; Tang, X.; Guo, M.; Lu, H.; Xu, X. Fabrication and characterization of non-enzymatic glucose sensor based on bimetallic hollow Ag/Pt nanoparticles prepared by galvanic replacement reaction. Ionics 2015, 21, 1417-1426. [CrossRef]

220. Singh, B.; Laffir, F.; McCormac, T.; Dempsey, E. PtAu/C based bimetallic nanocomposites for non-enzymatic electrochemical glucose detection. Sens. Actuators B Chem. 2010, 150, 80-92. [CrossRef]

221. Sheng, Q.; Mei, H.; Wu, H.; Zhang, X.; Wang, S. A highly sensitive non-enzymatic glucose sensor based on $\mathrm{Pt}_{\mathrm{x}} \mathrm{Co}_{1-\mathrm{x}} / \mathrm{C}$ nanostructured composites. Sens. Actuators B Chem. 2015, 207, 51-58. [CrossRef]

222. Bilal, S.; Ullah, W.; Shah, A.H.A. Polyaniline@CuNi nanocomposite: A highly selective, stable and efficient electrode material for binder free non-enzymatic glucose sensor. Electrochim. Acta 2018, 284, 382-391. [CrossRef]

223. Chawla, M.; Randhawa, J.K.; Siril, P.F. Calcination temperature as a probe to tune the non-enzymatic glucose sensing activity of $\mathrm{Cu}-\mathrm{Ni}$ bimetallic nanocomposites. New J. Chem. 2017, 41, 4582-4591. [CrossRef]

224. Lakhdari, D.; Guittoum, A.; Benbrahim, N.; Belgherbi, O.; Berkani, M.; Vasseghian, Y.; Lakhdari, N. A novel non-enzymatic glucose sensor based on NiFe (NPs)-polyaniline hybrid materials. Food Chem. Toxicol. 2021, 151, 112099. [CrossRef]

225. Mahshid, S.S.; Mahshid, S.; Dolati, A.; Ghorbani, M.; Yang, L.; Luo, S.; Cai, Q. Template-based electrodeposition of Pt/Ni nanowires and its catalytic activity towards glucose oxidation. Electrochim. Acta 2011, 58, 551-555. [CrossRef]

226. Ma, L.; Wang, X.; Zhang, Q.; Tong, X.; Zhang, Y.; Li, Z. Pt catalyzed formation of a Ni@Pt/reduced graphene oxide nanocomposite: Preparation and electrochemical sensing application for glucose detection. Anal. Methods 2018, 10, 3845-3850. [CrossRef]

227. Chen, X.; Tian, X.; Zhao, L.; Huang, Z.; Oyama, M. Nonenzymatic sensing of glucose at neutral pH values using a glassy carbon electrode modified with graphene nanosheets and Pt-Pd bimetallic nanocubes. Microchim. Acta 2014, 181, 783-789. [CrossRef]

228. Yang, J.; Liang, X.; Cui, L.; Liu, H.; Xie, J.; Liu, W. A novel non-enzymatic glucose sensor based on $\mathrm{Pt}_{3} \mathrm{Ru}_{1}$ alloy nanoparticles with high density of surface defects. Biosens. Bioelectron. 2016, 80, 171-174. [CrossRef] 
229. Lin, L.; Weng, S.; Zheng, Y.; Liu, X.; Ying, S.; Chen, F.; You, D. Bimetallic PtAu alloy nanomaterials for nonenzymatic selective glucose sensing at low potential. J. Electroanal. Chem. 2020, 865, 114147. [CrossRef]

230. Park, S.; Chung, T.D.; Kim, H.C. Nonenzymatic glucose detection using mesoporous platinum. Anal. Chem. 2003, 75, 3046-3049. [CrossRef]

231. Beden, B.; Largeaud, F.; Kokoh, K.B.; Lamy, C. Fourier transform infrared reflectance spectroscopic investigation of the electrocatalytic oxidation of d-glucose: Identification of reactive intermediates and reaction products. Electrochim. Acta 1996, 41, 701-709. [CrossRef]

232. Nantaphol, S.; Watanabe, T.; Nomura, N.; Siangproh, W.; Chailapakul, O.; Einaga, Y. Bimetallic Pt-Au nanocatalysts electrochemically deposited on borondoped diamond electrodes for nonenzymatic glucose detection. Biosens. Bioelectron. 2017, 98, 76-82. [CrossRef]

233. Shim, K.; Lee, W.C.; Park, M.S.; Shahabuddin, M.; Yamauchi, Y.; Hossain, M.S.A.; Shim, Y.B.; Kim, J.H. Au decorated core-shell structured Au@Pt for the glucose oxidation reaction. Sens. Actuators B Chem. 2019, 278, 88-96. [CrossRef]

234. Shim, K.; Lee, W.C.; Heo, Y.U.; Shahabuddin, M.; Park, M.S.; Hossain, M.S.A.; Kim, J.H. Rationally designed bimetallic Au@Pt nanoparticles for glucose oxidation. Sci. Rep. 2019, 9, 894. [CrossRef]

235. Zhang, H.; Wang, L.; Lu, L.; Toshima, N. Preparation and catalytic activity for aerobic glucose oxidation of crown jewel structured $\mathrm{Pt} / \mathrm{Au}$ bimetallic nanoclusters. Sci. Rep. 2016, 6, 30752. [CrossRef]

236. Tee, S.Y.; Teng, C.P.; Ye, E. Metal nanostructures for non-enzymatic glucose sensing. Mater. Sci. Eng. C 2017, 70, 1018-1030. [CrossRef]

237. Li, Z.; Qian, W.; Guo, H.; Long, X.; Tang, Y.; Zheng, J. Electrostatic Self-Assembled Bracelet-Like Au@Pt Nanoparticles: An Efficient Electrocatalyst for Highly Sensitive Non-Enzymatic Hydrogen Peroxide Sensing. ChemElectroChem 2020, 7, 1581-1589. [CrossRef]

238. Habrioux, A.; Sibert, E.; Servat, K.; Vogel, W.; Kokoh, K.B.; Alonso-Vante, N. Activity of platinum-gold alloys for glucose electrooxidation in biofuel cells. J. Phys. Chem. B 2007, 111, 10329-10333. [CrossRef]

239. Grochowska, K.; Ryl, J.; Karczewski, J.; Śliwiński, G.; Cenian, A.; Siuzdak, K. Non-enzymatic flexible glucose sensing platform based on nanostructured $\mathrm{TiO}_{2}$-Au composite. J. Electroanal. Chem. 2019, 837, 230-239. [CrossRef]

240. Parsons, R.; VanderNoot, T. The oxidation of small organic molecules: A survey of recent fuel cell related research. J. Electroanal. Chem. Interfacial Electrochem. 1988, 257, 9-45. [CrossRef]

241. Khawaji, M.; Zhang, Y.; Loh, M.; Graça, I.; Ware, E.; Chadwick, D. Composition dependent selectivity of bimetallic Au-Pd NPs immobilised on titanate nanotubes in catalytic oxidation of glucose. Appl. Catal. B Environ. 2019, 256, 117799. [CrossRef]

242. Zhang, H.; Toshima, N. Synthesis of Au/Pt bimetallic nanoparticles with a Pt-rich shell and their high catalytic activities for aerobic glucose oxidation. J. Colloid. Interface Sci. 2013, 394, 166-176. [CrossRef]

243. Dai, L.; Zhao, Y.; Chi, Q.; Liu, H.; Li, J.; Huang, T. Morphological control and evolution of octahedral and truncated trisoctahedral $\mathrm{Pt}-\mathrm{Au}$ alloy nanocrystals under microwave irradiation. Nanoscale 2014, 6, 9944-9950. [CrossRef]

244. Fan, Z.; Zhu, Y.; Huang, X.; Han, Y.; Wang, Q.; Liu, Q.; Huang, Y.; Gan, C.L.; Zhang, H. Synthesis of Ultrathin Face-Centered-Cubic Au@Pt and Au@Pd Core-Shell Nanoplates from Hexagonal-Close-Packed Au Square Sheets. Angew. Chem. 2015, 127, 5764-5768. [CrossRef]

245. Da Silva, S.G.; Silva, J.C.M.; Buzzo, G.S.; De Souza, R.F.B.; Spinacé, E.V.; Neto, A.O.; Assumpção, M.H.M.T. Electrochemical and fuel cell evaluation of PtAu/C electrocatalysts for ethanol electro-oxidation in alkaline media. Int. J. Hydrogen Energy 2014, 39, 10121-10127. [CrossRef]

246. Zhang, J.; Sasaki, K.; Sutter, E.; Adzic, R.R. Stabilization of platinum oxygen-reduction electrocatalysts using gold clusters. Science 2007, 315, 220-222. [CrossRef]

247. Jin, C.C.; Chen, Z.D. Electrocatalytic oxidation of glucose on gold-platinum nanocomposite electrodes and platinum-modified gold electrodes. Synth. Met. 2007, 157, 592-596. [CrossRef]

248. Moller, H.; Pistorius, P.C. The electrochemistry of gold-platinum alloys. J. Electroanal. Chem. 2004, 570, 243-255. [CrossRef]

249. Wu, Y.-S.; Wu, Z.-W.; Lee, C.-L. Concave Pd core/island Pt shell nanoparticles: Synthesis and their promising activities toward neutral glucose oxidation. Sens. Actuators B Chem. 2019, 281, 1-7. [CrossRef]

250. Coyle, V.E.; Oppedisano, D.K.J.; Jones, L.A.; Kandjani, A.E.; Sabri, Y.M.; Bhargava, S.K. Hydrogen Bubble Templated Growth of Honeycomb-Like Au-Pt Alloy Films for Non-Enzymatic Glucose Sensing. J. Electrochem. Soc. 2016, 163, B689. [CrossRef]

251. Wang, C.; Sun, Y.; Yu, X.; Ma, D.; Zheng, J.; Dou, P.; Cao, Z.; Xu, X. Ag-Pt hollow nanoparticles anchored reduced graphene oxide composites for non-enzymatic glucose biosensor. J. Mater. Sci. Mater. Electron. 2016, 27, 9370-9378. [CrossRef]

252. Ye, J.-S.; Hong, B.-D.; Wu, Y.-S.; Chen, H.-R.; Lee, C.-L. Heterostructured palladium-platinum core-shell nanocubes for use in a nonenzymatic amperometric glucose sensor. Microchim. Acta 2016, 183, 3311-3320. [CrossRef]

253. Song, Y.; Zhu, C.; Li, H.; Dua, D.; Lin, Y. A nonenzymatic electrochemical glucose sensor based on mesoporous Au/Pt nanodendrites. RSC Adv. 2015, 5, 82617-82622. [CrossRef]

254. Zhao, L.; Wu, G.; Cai, Z.; Zhao, T.; Yao, Q.; Chen, X. Ultrasensitive non-enzymatic glucose sensing at near-neutral pH values via anodic stripping voltammetry using a glassy carbon electrode modified with $\mathrm{Pt}_{3} \mathrm{Pd}$ nanoparticles and reduced graphene oxide. Microchim. Acta 2015, 182, 2055-2060. [CrossRef]

255. Li, Y.; Niu, X.; Tang, J.; Lan, M.; Zhao, H. A Comparative Study of Nonenzymatic Electrochemical Glucose Sensors Based on Pt-Pd Nanotube and Nanowire Arrays. Electrochim. Acta 2014, 130, 1-8. [CrossRef] 
256. Waqas, M.; Lan, J.; Zhang, X.; Fan, Y.; Zhang, P.; Liu, C.; Jiang, Z.; Wang, X.; Zeng, J.; Chen, W. Fabrication of Non-enzymatic Electrochemical Glucose Sensor Based on Pd-Mn Alloy Nanoparticles Supported on Reduced Graphene Oxide. Electroanalysis 2020, 32, 1226-1236. [CrossRef]

257. Şavk, A.; Aydın, H.; Cellat, K.; Şen, F. A novel high performance non-enzymatic electrochemical glucose biosensor based on activated carbon-supported Pt-Ni nanocomposite. J. Mol. Liq. 2020, 300, 112355. [CrossRef]

258. Şavk, A.; Cellat, K.; Arıkan, K.; Tezcan, F.; Gülbay, S.K.; Kızıldağ, S.; Işgın, E.S.; Şen, F. Highly monodisperse Pd-Ni nanoparticles supported on rGO as a rapid, sensitive, reusable and selective enzyme-free glucose sensor. Sci. Rep. 2019, 9, 19228. [CrossRef]

259. Wang, R.; Liang, X.; Liu, H.; Cui, L.; Zhang, X.; Liu, C. Non-enzymatic electrochemical glucose sensor based on monodispersed stone-like PtNi alloy nanoparticles. Microchim. Acta 2018, 185, 339. [CrossRef] [PubMed]

260. Qin, L.; He, L.; Zhao, J.; Zhao, B.; Yin, Y.; Yang, Y. Synthesis of Ni/Au multilayer nanowire arrays for ultrasensitive non-enzymatic sensing of glucose. Sens. Actuators B Chem. 2017, 240, 779-784. [CrossRef]

261. Mei, H.; Wu, W.; Yu, B.; Li, Y.; Wu, H.; Wang, S.; Xia, Q. Non-enzymatic sensing of glucose at neutral $\mathrm{pH}$ values using a glassy carbon electrode modified with carbon supported Co@Pt core-shell nanoparticles. Microchim. Acta 2015, 182, 1869-1875. [CrossRef]

262. Xue, Z.; Jia, L.; Zhu, R.-R.; Du, L.; Zhao, Q.-H. High-performance non-enzymatic glucose electrochemical sensor constructed by transition nickel modified Ni@Cu-MOF. J. Electroanal. Chem. 2020,858, 113783. [CrossRef]

263. Cui, D.; Su, L.; Li, H.; Li, M.; Li, C.; Xu, S.; Qian, L.; Yang, B. Non-enzymatic glucose sensor based on micro-/nanostructured $\mathrm{Cu} / \mathrm{Ni}$ deposited on graphene sheets. J. Electroanal. Chem. 2019, 838, 154-162. [CrossRef]

264. Li, W.; Lv, S.; Wang, Y.; Zhang, L.; Cui, X. Nanoporous gold induced vertically standing 2D NiCo bimetal-organic framework nanosheets for non-enzymatic glucose biosensing. Sens. Actuators B Chem. 2019, 281, 652-658. [CrossRef]

265. Pötzelberger, I.; Mardare, A.I.; Hassel, A.W. Non-enzymatic glucose sensing on copper-nickel thin film alloy. Appl. Surf. Sci. 2017, 417, 48-53. [CrossRef]

266. Jonke, A.P.; Josowicz, M.; Janata, J. Polyaniline Electrodes Containing Tri-Atomic Au/Pd Clusters: Effect of Ordering. Catal. Lett. 2013, 143, 1261-1265. [CrossRef]

267. Jonke, A.P.; Steeb, J.L.; Josowicz, M.; Janata, J. Atomic Clusters of Pd and $\mathrm{Au}_{\mathrm{N}} \mathrm{Pd}_{\mathrm{M}}$ in Polyaniline. Catal. Lett. 2013, 143, 531-538. [CrossRef]

268. Schwartz, I.T.; Jonke, A.P.; Josowicz, M.; Janata, J. Polyaniline Electrodes with Atomic $\mathrm{Au}_{\mathrm{n}} \mathrm{Pd}_{1}$ Alloys: Oxidation of Methanol and Ethanol. Catal. Lett. 2013, 143, 636-641. [CrossRef]

269. Chakraborty, P.; Chien, Y.-A.; Chiu, W.-T.; Chang, T.-F.M.; Sone, M.; Nakamoto, T.; Josowicz, M.; Janata, J. Design and development of amperometric gas sensor with atomic Au-Polyaniline/Pt composite. IEEE Sens. J. 2020, 20, 12479-12487. [CrossRef]

270. Schwartz, I.T.; Jonke, A.P.; Josowicz, M.; Janata, J. Effect of Structured Atomic Gold on Electrooxidation of Alcohols in Alkaline Medium. Catal. Lett. 2013, 143, 777-782. [CrossRef]

271. Jonke, A.P.; Josowicz, M.; Janata, J. Odd-Even Pattern Observed in Polyaniline/( $\left.\mathrm{Au}_{0}-\mathrm{Au}_{8}\right)$ Composites. J. Electrochem. Soc. 2012, 159, P40-P43. [CrossRef]

272. Jonke, A.P.; Josowicz, M.; Janata, J. Polyaniline Doped with Atomic Gold. J. Electrochem. Soc. 2011, 158, E147-E151. [CrossRef]

273. Tian, L.; He, G.; Cai, Y.; Wu, S.; Su, Y.; Yan, H.; Yang, C.; Chen, Y.; Li, L. $\mathrm{Co}_{3} \mathrm{O}_{4}$ based non-enzymatic glucose sensor with high sensitivity and reliable stability derived from hollow hierarchical architecture. Nanotechnology 2018, 29, 075502. [CrossRef]

274. Vilian, A.T.E.; Dinesh, B.; Rethinasabapathy, M.; Hwang, S.-K.; Jin, C.-S.; Huh, Y.S.; Han, Y.-K. Hexagonal Co $\mathrm{O}_{4}$ anchored reduced graphene oxide sheets for high-performance supercapacitors and non-enzymatic glucose sensing. J. Mater. Chem. A 2018, 6, 14367-14379. [CrossRef]

275. Yang, M.H.; Jeong, J.-M.; Lee, K.G.; Kim, D.H.; Lee, S.J.; Choi, B.G. Hierarchical porous microspheres of the $\mathrm{Co}_{3} \mathrm{O}_{4} @ g r a p h e n e$ with enhanced electrocatalytic performance for electrochemical biosensors. Biosens. Bioelectron. 2017, 89, 612-619. [CrossRef] [PubMed]

276. Fan, S.; Zhao, M.; Ding, L.; Liang, J.; Chen, J.; Li, Y.; Chen, S. Synthesis of 3D hierarchical porous $\mathrm{Co}_{3} \mathrm{O}_{4}$ film by eggshell membrane for non-enzymatic glucose detection. J. Electroanal. Chem. 2016, 775, 52-57. [CrossRef]

277. Zhang, E.; Xie, Y.; Ci, S.; Jia, J.; Wen, Z. Porous $\mathrm{Co}_{3} \mathrm{O}_{4}$ hollow nanododecahedra for nonenzymatic glucose biosensor and biofuel cell. Biosens. Bioelectron. 2016, 81, 46-53. [CrossRef]

278. Hoa, L.T.; Chung, J.S.; Hur, S.H. A highly sensitive enzyme-free glucose sensor based on $\mathrm{Co}_{3} \mathrm{O}_{4}$ nanoflowers and 3D graphene oxide hydrogel fabricated via hydrothermal synthesis. Sens. Actuators B Chem. 2016, 223, 76-82. [CrossRef]

279. Balouch, Q.; Ibupoto, Z.H.; Khaskheli, G.Q.; Soomro, R.A.; Sirajuddin; Samoon, M.K.; Deewani, V.K. Cobalt oxide nanoflowers for electrochemical determination of glucose. J. Electron. Mater. 2015, 44, 3724-3732. [CrossRef]

280. Li, M.; Han, C.; Zhang, Y.; Bo, X.; Guo, L. Facile synthesis of ultrafine $\mathrm{Co}_{3} \mathrm{O}_{4}$ nanocrystals embedded carbon matrices with specific skeletal structures as efficient non-enzymatic glucose sensors. Anal. Chim. Acta 2015, 861, 25-35. [CrossRef] [PubMed]

281. Khun, K.; Ibupoto, Z.H.; Liu, X.; Beni, V.; Willander, M. The ethylene glycol template assisted hydrothermal synthesis of $\mathrm{Co}_{3} \mathrm{O}_{4}$ nanowires; structural characterization and their application as glucose non-enzymatic sensor. Mater. Sci. Eng. B 2015, 194, 94-100. [CrossRef]

282. Yang, P.; Wang, X.; Ge, C.-Y.; Fu, X.; Liu, X.Y.; Chai, H.; Guo, X.; Yao, H.-C.; Zhang, Y.X.; Chen, K. Fabrication of CuO nanosheets-built microtubes via Kirkendall effect for non-enzymatic glucose sensor. Appl. Surf. Sci. 2019, 494, 484-491. [CrossRef] 
283. Jagadeesan, M.S.; Movlaee, K.; Krishnakumar, T.; Leonardi, S.G.; Neri, G. One-step microwave-assisted synthesis and characterization of novel CuO nanodisks for non-enzymatic glucose sensing. J. Electroanal. Chem. 2019, 835, 161-168. [CrossRef]

284. Wang, X.; Ge, C.-Y.; Chen, K.; Zhang, Y.X. An ultrasensitive non-enzymatic glucose sensors based on controlled petal-like CuO nanostructure. Electrochim. Acta 2018, 259, 225-232. [CrossRef]

285. Velmurugan, M.; Karikalan, N.; Chen, S.-M. Synthesis and characterizations of biscuit-like copper oxide for the non-enzymatic glucose sensor applications. J. Colloid Interface Sci. 2017, 493, 349-355. [CrossRef] [PubMed]

286. Zhang, Y.; Liu, Y.; Su, L.; Zhang, Z.; Huo, D.; Hou, C.; Lei, Y. CuO nanowires based sensitive and selective non-enzymatic glucose detection. Sens. Actuators B Chem. 2014, 191, 86-93. [CrossRef]

287. Lu, N.; Shao, C.; Li, X.; Shen, T.; Zhang, M.; Miao, F.; Zhang, P.; Zhang, X.; Wang, K.; Zhang, Y.; et al. CuO/Cur O nanofibers as electrode materials for non-enzymatic glucose sensors with improved sensitivity. RSC Adv. 2014, 4, 31056-31061. [CrossRef]

288. Ibupoto, Z.H.; Khun, K.; Beni, V.; Liu, X.; Willander, M. Synthesis of Novel CuO Nanosheets and Their Non-Enzymatic Glucose Sensing Applications. Sensors 2013, 13, 7926-7938. [CrossRef] [PubMed]

289. Ni, Y.; Xu, J.; Liang, Q.; Shao, S. Enzyme-free glucose sensor based on heteroatom-enriched activated carbon (HAC) decorated with hedgehog-like NiO nanostructures. Sens. Actuators B Chem. 2017, 250, 491-498. [CrossRef]

290. Zhao, B.; Wang, T.; Jiang, L.; Zhang, K.; Yuen, M.M.F.; Xu, J.B.; Fu, X.Z.; Sun, R.; Wong, C.P. NiO mesoporous nanowalls grown on RGO coated nickel foam as high performance electrodes for supercapacitors and biosensors. Electrochim. Acta 2016, 192, 205-215. [CrossRef]

291. Soomro, R.A.; Ibupoto, Z.H.; Sirajuddin; Abro, M.I.; Willander, M. Controlled synthesis and electrochemical application of skein-shaped NiO nanostructures. J. Solid State Electrochem. 2015, 19, 913-922. [CrossRef]

292. Ibupoto, Z.H.; Nafady, A.; Soomro, R.A.; Sirajuddin; Sherazi, S.T.H.; Abroe, M.I.; Willander, M. Glycine-assisted synthesis of NiO hollow cage-like nanostructures for sensitive non-enzymatic glucose sensing. RSC Adv. 2015, 5, 18773-18781. [CrossRef]

293. Guo, C.; Wang, Y.; Zhao, Y.; Xu, C. Non-enzymatic glucose sensor based on three dimensional nickel oxide for enhanced sensitivity. Anal. Methods 2013, 5, 1644-1647. [CrossRef]

294. Dung, N.Q.; Patil, D.; Jung, H.; Kim, J.; Kim, D. NiO-decorated single-walled carbon nanotubes for high-performance nonenzymatic glucose sensing. Sens. Actuators B 2013, 183, 381-387. [CrossRef]

295. Zhang, Y.Q.; Wang, Y.Z.; Jia, J.B.; Wang, J.G. Nonenzymatic glucose sensor based on graphene oxide and electrospun NiO nanofibers. Sens. Actuators B 2012, 171-172, 580-587. [CrossRef]

296. Zeid, E.F.A.; Nassar, A.M.; Hussein, M.A.; Alam, M.M.; Asiri, A.M.; Hegazy, H.H.; Rahman, M.M. Mixed oxides CuO-NiO fabricated for selective detection of 2-Aminophenol by electrochemical approach. J. Mater. Res. Technol. 2020, 9, $1457-1467$. [CrossRef]

297. Guo, Q.; Zeng, W.; Liu, S.; Li, Y. In situ formation of $\mathrm{Co}_{3} \mathrm{O}_{4}$ hollow nanocubes on carbon cloth-supported $\mathrm{NiCo}_{2} \mathrm{O}_{4}$ nanowires and their enhanced performance in non-enzymatic glucose sensing. Nanotechnology 2020, 31, 265501. [CrossRef] [PubMed]

298. Huang, M.; Luo, X.; He, D.; Jiang, P. Hierarchical Co $(\mathrm{OH})_{2}$ nanotube arrays grown on carbon cloth for use in non-enzymatic glucose sensing. Anal. Methods 2017, 9, 5903-5909. [CrossRef]

299. Zhang, L.; Yang, C.; Zhao, G.; Mu, J.; Wang, Y. Self-supported porous CoOOH nanosheet arrays as a non-enzymatic glucose sensor with good reproducibility. Sens. Actuators B Chem. 2015, 210, 190-196. [CrossRef]

300. Zhou, S.; Feng, X.; Shi, H.; Chen, J.; Zhang, F.; Song, W. Direct growth of vertically aligned arrays of $\mathrm{Cu}(\mathrm{OH})_{2}$ nanotubes for the electrochemical sensing of glucose. Sens. Actuators B Chem. 2013, 177, 445-452. [CrossRef]

301. Sim, H.; Kim, J.-H.; Lee, S.-K.; Song, M.-J.; Yoon, D.-H.; Lim, D.-S.; Hong, S.-I. High-sensitivity non-enzymatic glucose biosensor based on $\mathrm{Cu}(\mathrm{OH})_{2}$ nanoflower electrode covered with boron-doped nanocrystalline diamond layer. Thin Solid Films 2012, 520, 7219-7223. [CrossRef]

302. Mao, W.; He, H.; Ye, X.; Huang, J. Three-dimensional graphene foam integrated with Ni $(\mathrm{OH})_{2}$ nanosheets as a hierarchical structure for non-enzymatic glucose sensing. J. Electroanal. Chem. 2019, 832, 275-283. [CrossRef]

303. Zhao, Y.; Gu, G.; You, S.; Ji, R.; Suo, H.; Zhao, C.; Liu, F. Preparation of Ni $(\mathrm{OH})_{2}$ nanosheets on Ni foam via a direct precipitation method for a highly sensitive non-enzymatic glucose sensor. RSC Adv. 2015, 5, 53665-53670. [CrossRef]

304. Yang, J.; Cho, M.; Pang, C.; Lee, Y. Highly sensitive non-enzymatic glucose sensor based on over-oxidized polypyrrole nanowires modified with Ni $(\mathrm{OH})_{2}$ nanoflakes. Sens. Actuators B Chem. 2015, 211, 93-101. [CrossRef]

305. Kiani, M.A.; Tehrani, M.A.; Sayahi, H. Reusable and robust high sensitive non-enzymatic glucose sensor based on $\mathrm{Ni}(\mathrm{OH})_{2}$ nanoparticles. Anal. Chim. Acta 2014, 839, 26-33. [CrossRef]

306. Pal, N.; Banerjee, S.; Bhaumik, A. A facile route for the syntheses of $\mathrm{Ni}(\mathrm{OH})_{2}$ and $\mathrm{NiO}$ nanostructures as potential candidates for non-enzymatic glucose sensor. J. Colloid Interface Sci. 2018, 516, 121-127. [CrossRef] [PubMed]

307. Gao, A.; Zhang, X.; Peng, X.; Wu, H.; Bai, L.; Jin, W.; Wu, G.; Hang, R.; Chu, P.K. In situ synthesis of $\mathrm{Ni}_{(\mathrm{OH})} / \mathrm{TiO}_{2}$ composite film on NiTi alloy for non-enzymatic glucose sensing. Sens. Actuators B Chem. 2016, 232, 150-157. [CrossRef]

308. Sun, S.; Shi, N.; Liao, X.; Zhang, B.; Yin, G.; Huang, Z.; Chen, X.; Pu, X. Facile synthesis of CuO/Ni $(\mathrm{OH})_{2}$ on carbon cloth for non-enzymatic glucose sensing. Appl. Surf. Sci. 2020, 529, 147067. [CrossRef]

309. Mahmoudian, M.R.; Basirun, W.J.; Woi, P.M.; Sookhakian, M.; Yousefi, R.; Ghadimi, H.; Alias, Y. Synthesis and characterization of $\mathrm{Co}_{3} \mathrm{O}_{4}$ ultra-nanosheets and $\mathrm{Co}_{3} \mathrm{O}_{4}$ ultra-nanosheet-Ni $(\mathrm{OH})_{2}$ as non-enzymatic electrochemical sensors for glucose detection. Mater. Sci. Eng. C 2016, 59, 500-508. [CrossRef] 
310. Yu, J.; Zhao, X.; Zhao, Q.; Wang, G. Preparation and characterization of super-hydrophilic porous $\mathrm{TiO}_{2}$ coating films. Mater. Chem. Phys. 2001, 68, 253-259. [CrossRef]

311. Deegan, R.D.; Bakajin, O.; Dupont, T.F.; Huber, G.; Nagel, S.R.; Witten, T.A. Capillary flow as the cause of ring stains from dried liquid drops. Nature 1997, 389, 827-829. [CrossRef]

312. Lee, H.Y.; Park, Y.H.; Ko, K.H. Correlation between Surface Morphology and Hydrophilic/Hydrophobic Conversion of MOCVD- $\mathrm{TiO}_{2}$ Films. Langmuir 2000, 16, 7289-7293. [CrossRef]

313. Sakai, N.; Wang, R.; Fujishima, A.; Watanabe, T.; Hashimoto, K. Effect of Ultrasonic Treatment on Highly Hydrophilic TiO 2 Surfaces. Langmuir 1998, 14, 5918-5920. [CrossRef]

314. Chiu, W.-T.; Chen, C.-Y.; Chang, T.-F.M.; Tahara, Y.; Hashimoto, T.; Kurosu, H.; Sone, M. Fabrication and Photocatalytic Performance of Au/ZnO Layered Structure on Silk Textile for Flexible Device Applications. Electrochim. Acta 2017, 253, 39-46. [CrossRef] 